\title{
MASTER
}

RHO-BWI-CD-31

\section{The Hanford Site As It Relates To An Alternative Site For The Waste Isolation Pilot Plant: An Environmental Description}

K. R. Fecht, Editor

December 1978

Prepared for the United States

Department of Energy

Under Contract EY-77-C-06-1030

Rockwell International

Rockwell Hanford Operations

Energy Systems Group

Richland, WA 99352 


\section{DISCLAIMER}

This report was prepared as an account of work sponsored by an agency of the United States Government. Neither the United States Government nor any agency Thereof, nor any of their employees, makes any warranty, express or implied, or assumes any legal liability or responsibility for the accuracy, completeness, or usefulness of any information, apparatus, product, or process disclosed, or represents that its use would not infringe privately owned rights. Reference herein to any specific commercial product, process, or service by trade name, trademark, manufacturer, or otherwise does not necessarily constitute or imply its endorsement, recommendation, or favoring by the United States Government or any agency thereof. The views and opinions of authors expressed herein do not necessarily state or reflect those of the United States Government or any agency thereof. 


\section{DISCLAIMER}

Portions of this document may be illegible in electronic image products. Images are produced from the best available original document. 
THE HANFORD SITE AS IT RELATES TO

AN ALTERNATIVE SITE FOR THE WASTE ISOLATION PILOT PLANT:

AN ENVIRONMENTAL DESCRIPTION

K. R. Fecht, Editor

for

Basalt Waste Isolation Program

DECEMBER 1978

PREPARED BY ROCKWELL HANFORD OPERATIONS

AND PACIFIC NORTHWEST LABORATORY FOR

THE U. S. DEPARTMENT OF ENËRGY

This report was prepared as an account of work This report was prepared as an account of work
sponsored by the United Siates Govemment. Neither the United States nor the United States Department of
United the Energy, nor any of thels employees, nor any of their Energy, nor any of thels employees, not any of their
contractors, subcontractors, or their employees, makes contractors, subcontractors, or their employees, makes any warranty, express or implied, or assumes any legal or usefulness of any information apparatus complet teness or usefulness of any information, apparatus, product or
process disclosed, or represents that its use would not process disclosed, or represents that its use would not infringe privately owned rights.

\section{DISTRIBUTION OF THIS DOCUMENT IS UNLIMLTED}

$$
\text { bLA }
$$

THIS DOCUMENT CLEARED

FOR PUBLIC RELEASE ON

JULY 23, 1979 
Issue Approval:
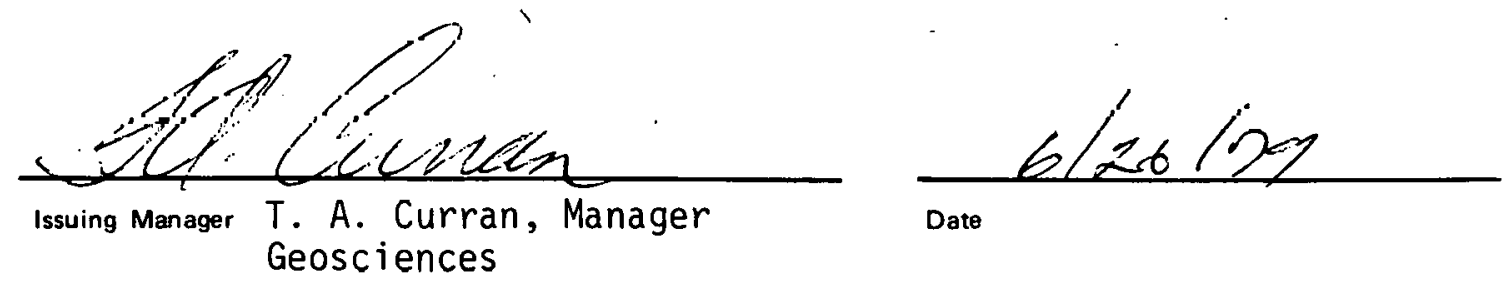

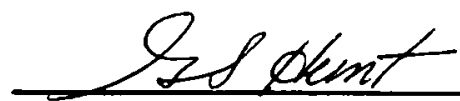

G. S. Hunt, Manager

Concurring Approval G. S. Hun
Licensing
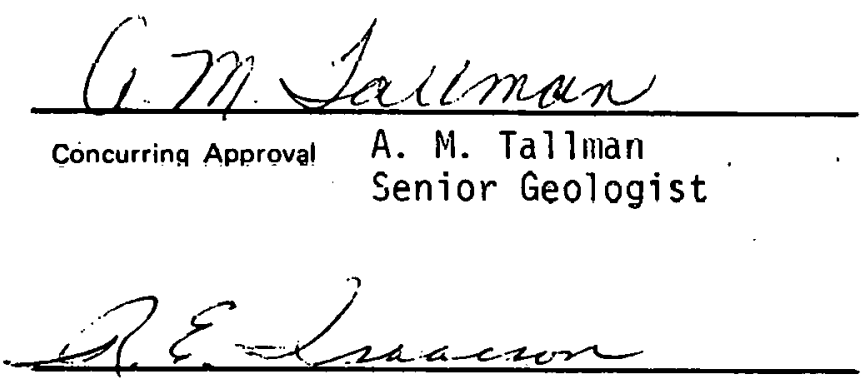

Program Office Representative

R. E. Isaacson

Systems Integration

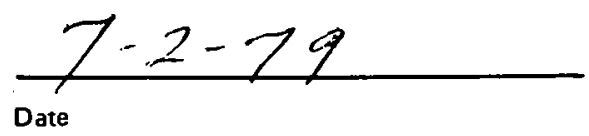

\section{Rockwell Internatio
Rockwell Hanford Operations Energy Systems Group}

$6 / 29 / 79$

Date 
TABLE OF CONTENTS

1.0 INTRODUCTION . . . . . $1-1$

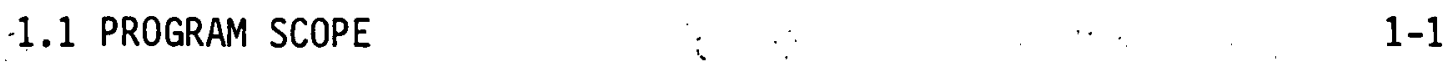

1.2 PROGRAM COSTS AND RELATED SCHEDULES $1-1$

1.2.1 RESEARCH AND DEVELOPMENT COSTS ;

1.2.2 CONSTRUCTION COSTS $\quad 1-2$

1.2.3. SCHEDULE ACCELERATION . 1-4

1.3 COMPARISON OF BWIP SCHEDULE AND COST . . 1-4

TO THOSE FOR A REPOSITORY IN SALT

1.4 SITE LOCATION $1-7$

2.0 DEMOGRAPHY $\quad \cdots \quad \cdot 2-1$

2.1 POPULATION 2-1

2.2 LAND USE $\quad 2-1$

3.0 ECOLOGY 3-1

3.1 AQUATIC ECOLOGY 3-1

3.1.1 COLUMBIA RIVER 3-1

3.1.2 HANFORD PONDS AND DITCHES ? 3-4

3.1.3 RATTLESNAKE SPRINGS 3-5

3.2 TERRESTRIAL ECOLOGY 3-5

3.2.1 VEGETATION 3-7

3.2.2 MAMMALS 3-7

3.2.3 BIRDS 3-9

3.2.4 INSECTS ON THE 200 AREAS PLATEAU 3-10

3.2.5 COLD-BLOODED INVERTEBRATES 3-11

3.3 RARE, THREATENED, AND ENDANGERED SPECIES 3-11

4.0 CLIMATOLOGY 4-1

5.0 PHYSIOGRAPHY $5-1$ 
Table of Contents (continued)

$\underline{\text { Page }}$

5.1 COLUMBIA PLATEAU PHYSIOGRAPHIC PROVINCE

5.1.1 COLUMBIA BASIN SECTION

$5-1$

5.1.2 BLUE MOUNTAINS SECTION

$5-4$

5.1.3 HARNEY-SNAKE RIVER PLATEAU SECTION

5.2 NORTHERN ROCKY MOUNTAINS PHYSIOGRAPHIC PROVINCE

5.2.1 OKANOGAN HIGHLANDS SECTION

5.2.2 IDAHO-MONTANA NORTHERN ROCKY MOUNTAINS SECTION

5.2.3 IDAHO BATHOLITH SECTION

5.3 CASCADE RANGE PHYSIOGRAPHIC PROVINCE

5.4 PACIFIC BORDER PHYSIOGRAPHIC PROVINCE

5.4.1 PUGET-WILLAMETTE LOWLANDS SECTION 5-6

5.4.2 COASTAL RANGE SECTION 5-6

6.0 HYDROLOGY $6-1$

6.1 REGIONAL HYDROGEOLOGY 6-1

6.2 CONFINED AQUIFER SYSTEMS 6-4

6.2.1 HANFORD VICINITY $6-4$

6.2.2 HANFORD SITE 6-6

6.3 UNCONFINED AQUIFER SYSTEM 6-8

6.4 UNSATURATED ZONE $6-15$

6.5 SURFACE HYDROLOGY 6-16

6.5.1 TOPOGRAPHY AND DRAINAGE 6-16

6.5.2 COLUMBIA RIVER 6-18

6.5.3 YAKIMA RIVER 6-20

6.5.4 SURFACE WATER ON THE HANFORD SITE . $6-20$

6.5.5 FLOODS 6-22 
Table of Contents (continued)

Page

7.0 GEOLOGY

$7-1$

7.1 REGIONAL GEOLOGY

$7-1$

7.1.1 COLUMBIA BASIN

7-1

7.1.2 BLUE MOUNTAINS

$7-1$

7.1.3 HARNEY REGION

$7-1$

7.1.4 IDAHO BATHOLITH

$7-4$

7.1.5 IDAHO-MONTANA: NORTHERN ROCKY MOUNTAINS

7-4

7.1 .6 OKANOGAN HIGHLANDS

$7-4$

7.1.7 CASCADE RANGE

$7-4$

7.1.8 PUGET-WILLAMETTE TROUGH

7.1.9 COAST RANGE

7.2 GEOLOGIC SETTING OF THE HANFORD SITE

$7-6$

7.3 GEOLOGY OF THE HANFORD SITE

$7-8$

7.3.1 STRATIGRAPHY

$7-8$

7.3.1.1 BASEMENT ROCKS

$7-13$

7.3.1.2 THE COLUMBIA RIVER BASALT GROUP

$7-13$

7.3.1.3 ELLENSBURG FORMATION

$7-15$

7.3.1.4 RINGOLD FORMATION

$7-16$

7.3.1.5 PALOUSE SOILS

$7-16$

7.3.1.6 HANFORD FORMATION

$7-17$

7.3.1.7 VOLCANIC ASH DEPOSITS

$7-17$

7.3.1.8 EOLIAN - DEPOSITS

$7-18$

7.3.2 STRUCTURE

7-18

1.3.2.1 FOLUS

$7-18$

7.3.2.2. FAULTS

$7-19$ 
Table of Contents (continued)

Page

7.3.2.3 TECTONIC STRUCTURES

7-19

7.3.2.3.1 GABLE MOUNTAIN

7-19

7.3.2.3.2 GABLE BUTTE

7-19

7.3.2.3.3 UMTANUM RIDGE

$7-21$

7.3.2.3.4 SADDLE MOUNTAINS

$7-21$

7.3.2.3.5 YAKIMA RIDGE

$7-21$

7.3.2.3.6 RATTLESNAKE-WALLULA LINEAMENT

$7-22$

7.4 MINERAL RESOURCES

$7-23$

7.4.1 WATER

$7-23$

7.4.2 SAND AND GRAVEL

$7-23$

7.1 .3 BASALT

$7-23$

7.4 .4 GAS

$7-23$

7.4.5 OTHER MINERAL RESOURCES

$7-24$

8.0 SEISMOLOGY OF THE HANFORD SITE AND ADJACENT AREAS

$8-1$

8.1 EARTHQUAKE HISTORY

8-1

8.2 CORRELATION OF EPICENTERS WITH GEOLOGIC STRUCTURES

8-5

8.3 IDENTIFICATION OF CAPABLE FAULTS

8-8

8.4 MAXIMUM HISTORIC EARTHQUAKE

$8-9$

8.5 SUMMARY

$8-1.0$

9.0 HISTORICAL AND ARCHEOLOGICAL SITES

9-1

$10.0^{\circ}$ REFERENCES

$10-1$

APPENDIX - DESCRIPTION AND PROPERTIES OF COLUMBIA RIVER BASALT

A-1

DISTRIBUTION

B-1 


\section{LIST OF FIGURES}

Page

FIGURE 1.1 LOCATION OF THE 'HANFORD SITE $1-8$

FIGURE 2.1 COMMUNITIES AROUND THE HANFORD SITE $2-2$

FIGURE 2.2 HANFORD VICINITY LAND USE $2-4$

FIGURE 3.1 FOOD WEB IN THE COLUMBIA RIVER $3-2$

FIGURE 3.2 FOOD WEB IN GABLE MOUNTAIN POND AND U POND

FIGURE 3.3 VEGETATION CLASSIFICATION AND DISTRIBUTION OF MAJOR VEGETATION TYPES ON THE HANFORD SITE

FIGURE 4.1 TOTAL ANNUAL PRECIPITATION PROBABILITY 4-3

FIGURE 4.2 ROSE DIAGRAMS OF SURFACE WINDS AT HANFORD

FIGURE 5.1 PHYSIOGRAPHIC PROVINCES

$5-2$

FIGURE 5.2 GENERAL TOPOGRAPHY OF HANFORD AREA

$5-3$

FIGURE 6.1

WATER LEVELS IN A WELL NEAR ODESSA, WASHINGTON SHOWING 6-5 ISOLATION BETWEEN AQUIFERS

FIGURE 6.2 PASCO BASIN UPPERMOST CONFINED AQUIFER POTENTIAL MAP

FIGURE 6.3

HANFORD SITE WATER TABLE MAP - DECEMBER 1976

$6-10$

FIGURE 6.4 BOTTOM OF UNCONF INED AQUIFER SYSTEM

FIGURE 6.5 HANFORD SITE FLOW SYSTEM

FIGURE 6.6 SURFACE WATER AREAS ON THE HANFORD SITE

FIGURE 6.7 COLUMBIA RIVER DRAINAGE BASIN

FIGURE 7.1 REGIONAL GEOLOGIC MAP

$7-2$

FIGURE 7.2

REGIONAL TECTONIC MAP

FIGURE 7.3

GEOGRAPHIC EXTENT OF COLUMBIA RIVER BASALT

FIGURE 7.4

PASCO BASIN STRATIGRAPHIC NOMENCLATURE

FIGURE 7.5 MAIN AXIS UF THE YASLÜ BASIN 
List of Figures (continued)

Page

FIGURE 7.7 EAST-WEST CROSS SECTION OF LATE CENOZOIC SEDIMENTS IN PASCO BASIN

FIGURE 7.8 TECTONIC MAP OF HANFORD AREA

FIGURE 8.1 MICROEARTHQUAKE EPICENTERS, HANFORD SITE REGION 8-3

FIGURE 9.1 ARCHEOLOGIC SITES ON AND NEAR THE HANFORD SITE $9-2$

FIGURE A.1 MAJOR INTRAFLOW STRUCTURES OF TYPICAL COLUMBIA RIVER BASALT FLOW

FIGURE A.2 EFFECT OF TEMPERATURE ON THERMAL CONDUCTIVITY, DRILL HOLE DC-10

A-6

\section{LIST OF TABLES}

TABLE 1.1 SUMMARY OF ESTIMATED RESEARCH AND. DEVELOPMENT COST AND SCHEDULE FOR THE FIRST MINED BASALT RESPOSITORY

TABLE 1.2 SUMMARY OF RESEARCH AND DEVELOPMENT COST AND SCHEDULE FOR THE FIRST MINED GEOLOGIC REPOSITORY

TABLE 1.3

COMPARISON OF ESTIMATED COSTS

TABLE 3.1

AMPHIBIAN AND REPTILE SPECIES OBSERVED ON THE HANFORD SITE

TABLE 6.1 HYDROGEOLOGIC CHARACTERISTICS OF THE PASCO BASIN

TABLE 6.2 HYDRAULIC PROPERTIES OF THE CONFINED AQUIFER SYSTEMS AT HANFORD

TABLE 6.3 SELECTED HYDRAULIC PROPERTIES OF THE UNCONFINED AQUIFER SYSTEM

TABLE 6.4 AVERAGE CHEMICAL CONCENTRATIONS IN THE COLUMBIA RIVER AT PRIEST RAPIDS DAM, OCTOBER 1971 TO SEPTEMBER 1972

TABLE 6.5 PHYSICAL AND CHEMICAL CHARACTERISTICS OF PONDS ON THE HANFORD SITE

TABLE 6.6 PHYSICAL AND CHEMICAL CHARACTERISTICS FOR STREAMS (DITCHES AND TRENCHES) ON THE HANFORD SITE

TABLE 8.1 RECENT WESTERN WASHINGTON EARTHQUAKES EXPECTED RANGE FOR AVERAGE BASALT 


\subsection{INTRODUCTION}

\subsection{PROGRAM SCOPE}

The use of basalt at Hanford as an alternative for the Waste Isolation Pilot Plant (WIPP) would require that the present Basalt Waste Isolation Program (BWIP) at Hanford be expanded to incorporate the planned WIPP functions, namely the permanent storage of transuranic (TRU) wastes. The other WIPP function of testing the means of storing spent fuel would be satisfied by related programs already in progress within BWIP.

The repository concept of BWIP currently includes means to permanently store (with a short-range retrievability period) spent fuel, high-level (HLW), and low-level (LLW) radioactive wastes.

The scope of the BWIP would require modification to accommodate the TRU wastes in addition to those listed.

\subsection{PROGRAM COSTS AND RELATED SCHEDULES}

The costs of BWIP are addressed in terms of: (a) a research and development (R\&D) program that leads to a feasibility and licensing verification; and (b) a construction and operating permit.

Since the incremental costs of adding the TRU storage function to the BWIP cannot be isolated in this preliminary program stage, the cost discussions that follow will only be related to the current BWIP functions. It may be summarized that the addition of TRU will not appreciably increase the technology $R \& D$ costs, since the radioisotopes of concern in the TRU are also contained within the spent fuel to be stored by BWIP. Design, development, and system integration costs will be impacted because of different handling and storage requirements as well as the need to increase repository capacity. The lower decay heat generation rates of TRU would need to be factored into the areal heat density requirements of the repository.

\subsubsection{Research and Development Costs}

Preliminary estimates of the cost for the R\&D associated with the development of a Hanford repository are shown in Table 1.1. These estimates are based on a program with the following milestones. 
TARLE 1.1

SUMMARY DF ESTIMATED RESEARCH F.ND GEVELOPMENT COST AND SCHEDULE

FOR THE FIRS? MINED BASALT REPOSITORY*

(Dollars in $M=11$ ions)

\section{Years to Construction License}

Site Evaluation, Qualificition, and Systems Integration

Engineered Barriers

Rock Mechanics and Therma" Design Parameters - Near-Surface Test Facility

Repository Engineering and Cesign Leading to a Construction Permit

TOTAL

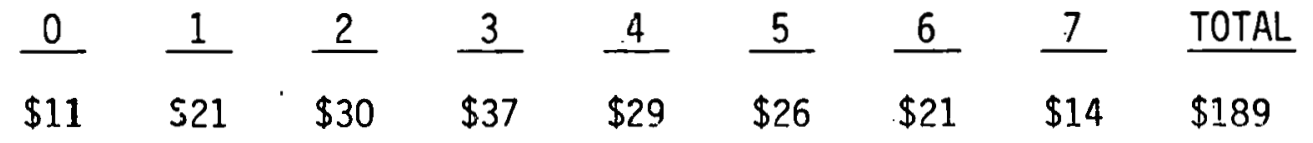

$\begin{array}{lllllllll}2 & 5 & 5 & 5 & 3 & 3 & 4 & 3 & 30\end{array}$

$\begin{array}{lllllllll}15 & 19 & 12 & 8 & 15 & 15 & 17 & 11 & 112\end{array}$

$\begin{array}{lllllllll}2 & 8 & 10 & 17 & 7 & 7 & 9\end{array}$

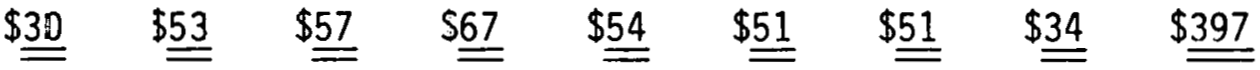

*These preliminary estimates are based upon the best available information and could change significantly. The estinates are based on BiNIP planning estimates $(1)$ beginning in FY 1979 and extending to construction licensing. 


\section{Fiscal Year}

Select Candidate Sites

1979

Select Final Sites

1981

Submit Environmental Report

1983

Receive Construction Permit

1986

The R\&D program costs covered in Table 1.1 are estimated from current planning estimates from the program plan for the BWIP; ${ }^{(1)}$ Title I and Title II design costs, mining, and construction costs are not included.

Because much of the R\&D leading to an environmental report is site specific, implementation of the schedule requires selection of a candidate site within two years after program inception. Other factors that influence the schedules include licensing, transportation, retrievability, and the step-wise repository activation sequence.

\subsubsection{Construction Costs}

Construction costs for a Hanford Site have not been estimated in any. degree of detail. Preliminary estimates for a repository (HLW, LLW, and spent fuel) have been presented in the Interagency Review Group (IRG) assessment. (2)

"These costs are estimated to be about $\$ 500$ million for design, ronstrur.tion, test.ing, and clnsure, and roughly $\$ 100$ million in operating costs per year. Assuming the operating life of the repository is 10 years, the total repository cost is about $\$ 1,500$ million. The costs of repositories themselves will, therefore, dominate the long-term resources expended in (commercial) waste management programs for any strategy."

It should be noted that the construction costs that might be allocated for TRU waste storage space would be conșiderably leș than the IRG gross estimates.

Candidates for BWIP sites will be selected in FY 1979 and the draft environmental impact statement will be completed in FY 1983. 


\subsubsection{Schedule Acceleration}

The idealized schedules represented in Table 1.1 are paced by the time needed to perform R\&D work and to characterize sites, and much of this work cannot be significantly accelerated by increased funding. There is a limited availability of drilling rigs, and the time to take rock cores and analyze the results is rather fixed. The time to perform in situ tests probably cannot be shortened very much. In general, a rapid increase in annual expenditures would probably be 1 imited by the availability of required equipment and trained and experienced scientists, engineers, and technicians.

1.3 COMPARISON OF THE BASALT WASTE ISOLATION PROGRAM SCHEDULE AND COST TO THOSE FOR A REPOSITORY IN SALT

Preliminary estimates of the R\&D costs and schedules for the first repository in salt are given in Table 1.2. (3) Significant differences between the basalt and salt repository R\&D programs exist, especially in the area of thermal analysis and rock mechanics ( $\$ 112 \mathrm{million}$ and $\$ 20$ million, respectively). The BWIP includes the cost of the Near-Surface Test Facility for obtaining thermal analyses and rock mechanics data from in situ heater tests and in situ spent fuel tests. In the case of salt, thermal rock mechanics tests were completed in the Oak Ridge National Laboratory test facility at Lyons, Kansas. Also, similar data exist from tests made in the Asse Salt Mine in West Germany.

Site evaluation, qualification, and systems integration costs for BWIP of $\$ 189$ million can be compared to the sum of "System Data Base Development" ( $\$ 40 \mathrm{million})$, "Development of Techniques for Analyzing Geologic Formations" ( $\$ 80$ million), "Verification of Safety and Reliability" (\$50 million)--a total of $\$ 170$ million. The generic environmental impact statement ${ }^{(3)}$ (GEIS) estimates do not include the engineering and designing costs required for a construction permit ( $\$ 66$ million), but do include the costs for "Development of Decommissioning and Monitoring Techniques" ( $\$ 30$ million). The "Engineered Barriers" ( $\$ 30$ million) costs in the BWIP can be compared to the "Rock-Waste Interactions" ( $\$ 30$ million) in the GEIS. These cost data are summarized in Table 1.3. 


\section{TABLE 1.2}

SUMMARY OF RESEARCH AND DEVELOPMENT COST

AND SCHEDULE FOR THE FIRST MINED GEOLOGIC REPOSITORY

(1978 Dollars in Millions Without Inflation Factor 3 *)

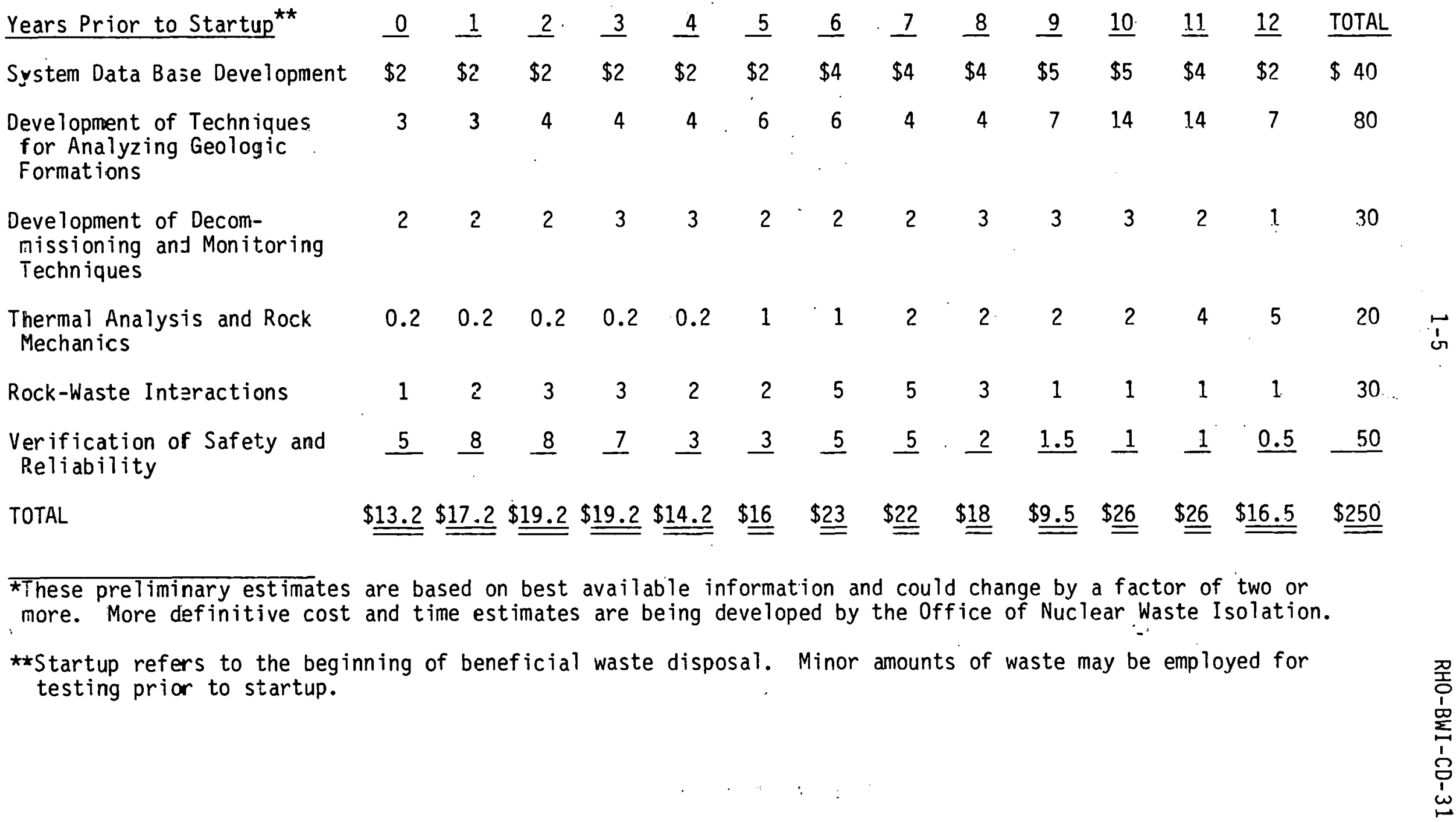


TABLE 1.3

COMPARISON OF ESTIMATED COSTS

(Dollars in Millions)

Site Qualification

Design

Thermal Analyses

Engineered Barriers

Decommissioning

TOTAL

$\frac{B W I P}{\$ 189}^{(1)} \quad \frac{\text { GEIS }}{\$ 170}^{(3)} \quad \frac{\text { DIFFERENCE }}{\$ 19}$

66

112

20

30

0

- $\quad 30$

$(\underline{30)}$

$\$ 397$

$\$ 250$

$\$ 147$ 


\subsection{SITE LOCATION}

The Hanford Site is a 1,500-square-kilometer tract of semi-arid land in south-central Washington state (Figure-1.1). The site, with major dimensions of approximately 52 kilometers north-south and 42 kilometers east-west, lies primarily west and south of the section of the Columbia River immediately north of Richland, Washington. Richland lies about 5 kilometers from the most southern portion of the Hanford Site boundary, and is the closest population center. 


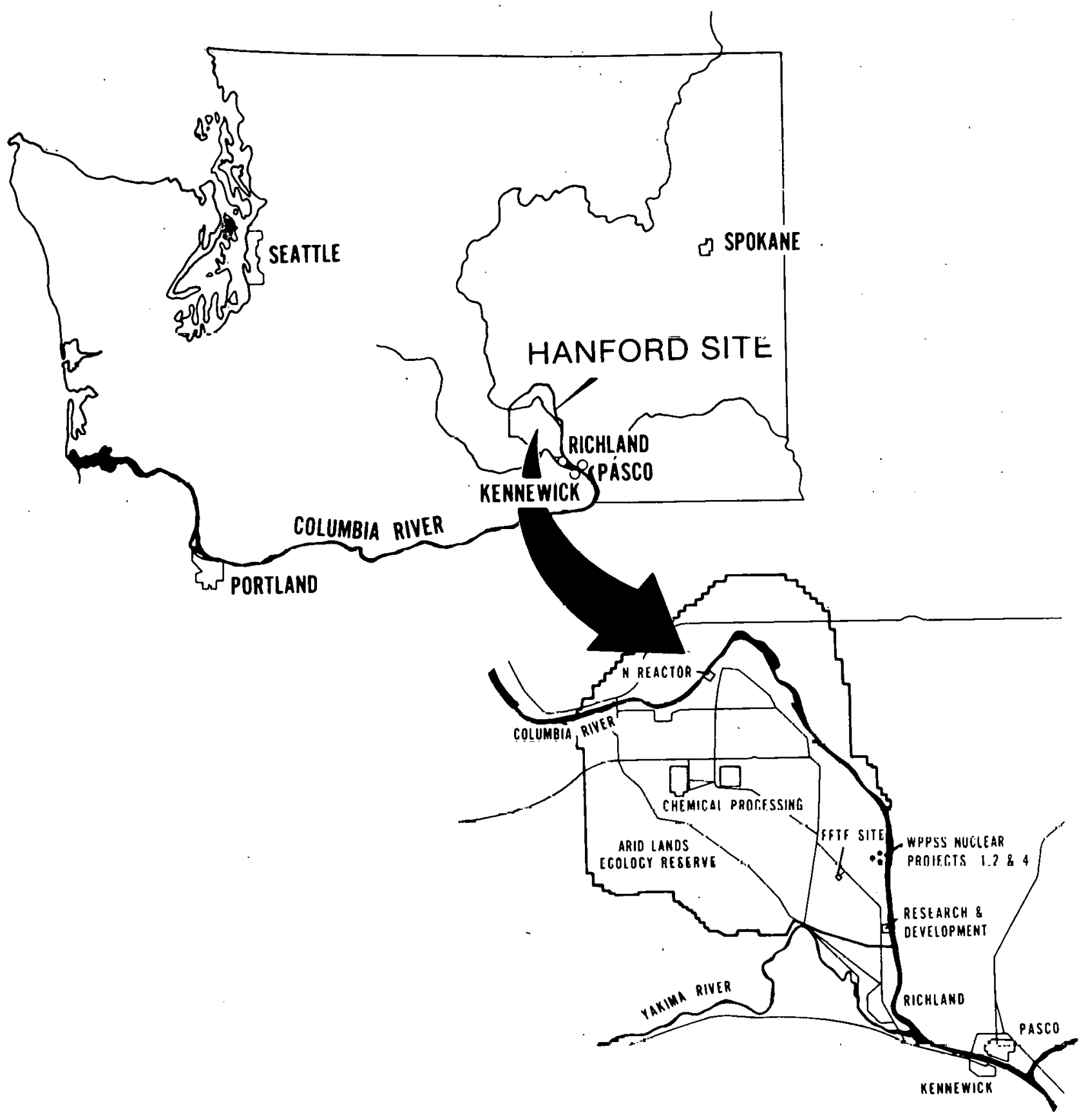

FIGURE 1.1 


\subsection{DEMOGRAPHY $(1,2)$}

\subsection{POPULATION}

The generalized location of the Hanford Site and surrounding population centers are shown in Figure 2.1. An estimated 250,000 people live within an 80-kilometer radius of the Hanford Meteorological Station (HMS) which is located between the 200 East and 200 West areas. This is about 12 people per square kilometer.

Population estimates for the region have been made for 1973, 1977 , 1981 , and $2000^{(3-9)}$ using 1970 census information, current birth rate trends, and estimates of net migration into or out of the state as economic and employment opportunities change over the forecast period. The mean growth rate up to the year 2000 for the region is estimated to be about 0.7 percent per year. The forecast does not reflect the population expansion which would result from the creation of a nuclear park or a more intensive utilization of nuclear energy for power generation and other purposes. It is assumed that the major portion of the Hanford Site will remain under the management of the Federal Government and that no persons will reside within the controlled site boundaries. The population residing in the unincorporated area was calculated on the basis of population density in the portion of a specific census district within the site area. This assumes an even distribution of population throughout the unincorporated areas of each census district. It was further assumed that the rate of population growth was the same for both incorporated and unincorporatcd arcas.

\subsection{LAND USE}

Before the arrival of Europeans, the native Indian tribes lived largely on fish from the Columbia River and on natural plant products. The earliest use by white immigrants of the Hanford Site was for stock grazing in a seasonal pattern. In the first decadc of the twentieth century, several small, privately irrigated farms were put into rultivation. The Hanford Irrigation Project, taking water from the river above Coyote Rapids (upstream from 100-K Area), supplied a small but 


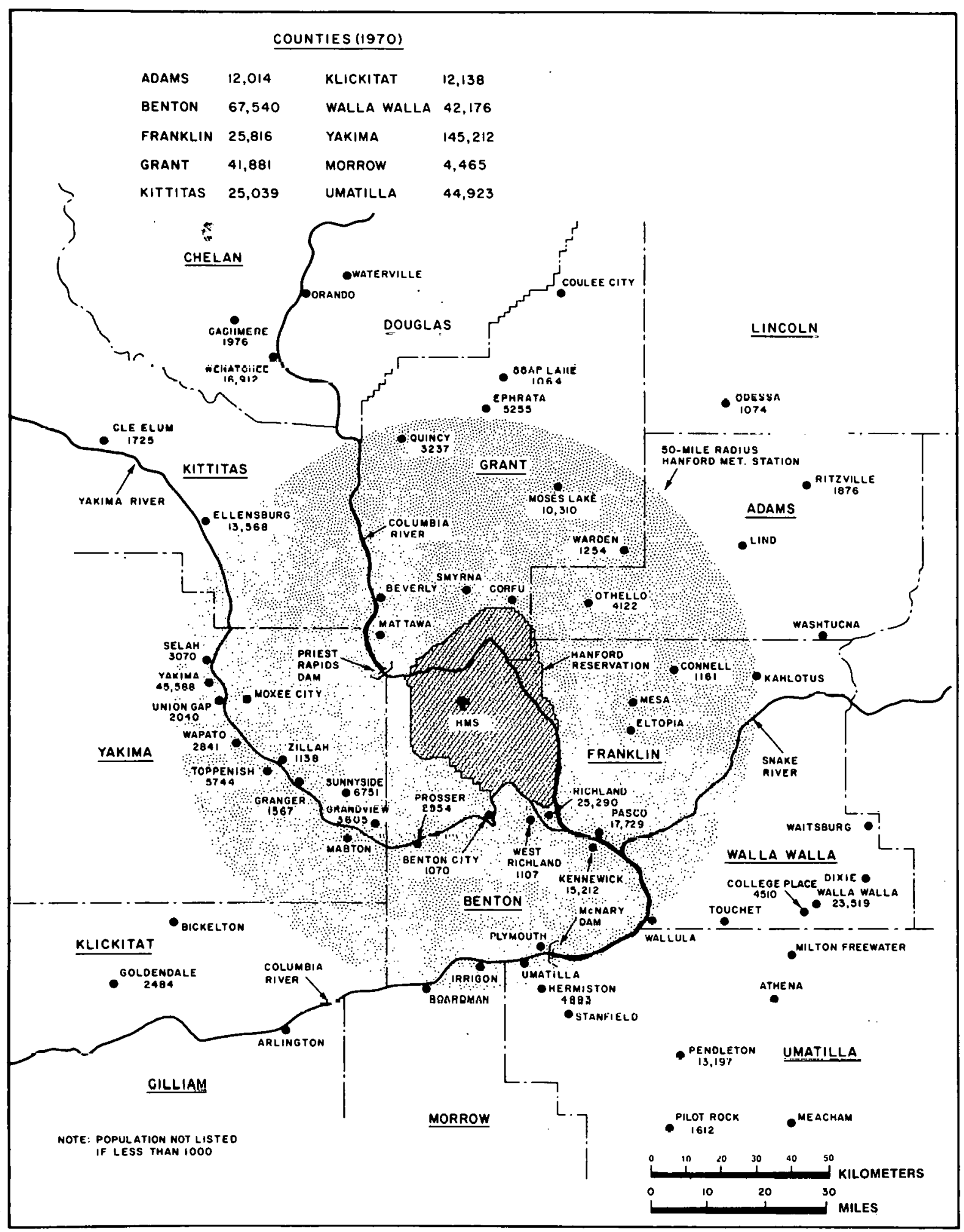

FIGURE 2.1 
flourishing irrigated orchard and farm economy along the river as far downstream as the Hanford town site until the Federal Government purchased the land to construct the Hanford Engineering Works.

The nature and extent of present land use is discussed here on the basis of arcs described from the HMS. Land areas included in an 80-kilometer radius from the site are discussed below.

Figure 2.2 shows the Hanford Site map with sector markings overlaid. Starting from a line directly north from the HMS, the 0- to 16-kilometer zone is entirely within the Hanford Site boundaries. The area south of the Columbia River is under control and is a limited access area. Land north of the river is controlled by the U. S. Bureau of Sport Fisheries and Wildlife as a game refuge. All of this zone between the 0 - and 150-degree radials is limited access area. Most of the zone between the 150- and 270-degree radials consists of the Arid Lands Ecology (ALE) Reserve, which is also limited access 1 and under the control of Pacific Northwest Laboratory. Between the 270-degree radial and the starting radial, land south of the Columbia River is controlled limited access; while north of the river, the game refuge is again encountered.

Again starting from the 0 -degree radial, the 16- to 32-kilometer zone is a continuation of the game refuge with some areas open for fishing and hunting. Farther north, this zone includes the easternmost portion of the Wahluke Slope and the Saddle Mountains. Between the Wahluke Branch Canal and the Columbia River, the zone consists of lands in the Columbia Basin Irrigation Project which are irrigated or are being developed for irrigation. The area west of the river is limited access Hanford Site. Leaving the site boundary, the land is mainly unirrigated and used for cattle and sheep grazing. South and west of the Columbia River, in the vicinity of Priest Rapids Dam, is the U. S. Army-Yakima Firing Range which is undeveloped, unpopulated land. Northwest of Priest Rapids Dam and Reservoir is the Wahluke Slope portion of the Columbia Basin Irrigation Project. This area is partially irrigated with the rest (outside the Hanford Site) expected to be irrigated in the next 10 years. 


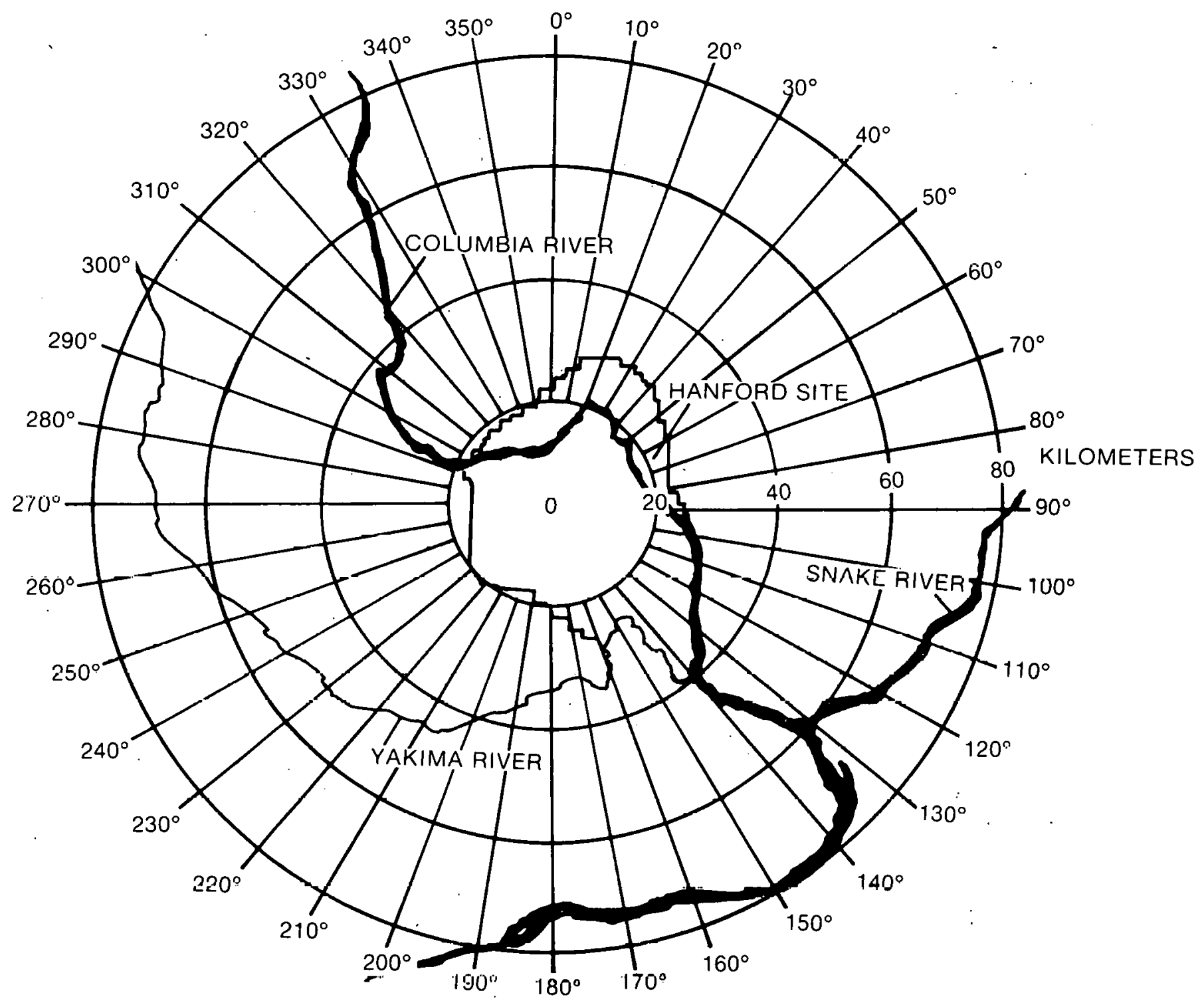

V7902-4.1

FIGURE 2.2 
The 32- to 48-kilometer zone on the 0 -degree radial is north of the Saddle Mountains and is irrigated farm land, part of the Columbia Basin Irrigation Project. The area from lower Crab Creek to northwest of Othello is generally undeveloped. From Othello south to the Columbia River, the land is irrigated farm 1 and. On the west side of the river is the city of Richland. West from Richland, the 32- to 48-kilometer zone includes the Yakima River and the towns of Prosser, Sunnyside, Grandview, and Mabton. Land along the Yakima River is primarily in orchard use. Higher land away from the valley floor is used primarily for grazing livestock with some land used for grain crops. At approximately the 270-degree radial, the U.S. Army-Yakima Firing Range is again encountered. At 320 degrees is the Ginkgo Petrified Forest, a registered national landmark.

At the 0-degree radial, the 48- to 64-kilometer zone consists of an undeveloped area of sagebrush and sand dunes. At 20 degrees, the Potholes Reservoir, a recreation area surrounded by sand dunes, is located south of Moses Lake. Between 30 and 50 degrees, this zone encompasses a major portion of the Columbia Basin Irrigation Project. At approximately the 130-degree radial, the Columbia River is encountered, with the city of Pasco on the north side and the city of Kennewick on the south side. South and west of Kennewick, the 48- to 64-kilometer zone runs south to the Horse Heaven Hills. Although this land is primarily used for dry-1and wheat farming, there are about 88 sections (230 square $\mathrm{kil}$ ometers) where permits have been granted for private irrigation development. Crossing the Horse Heaven Hills, the zone includes part of the Yakima Valley containing the towns of Granger, Toppenish, Zillah, and Wapato. This land is largely in orchards and other truck crops, with livestock grazing at the higher elevations. Northeast of Yakima is the U. S. Army Yakima Firing Range, east of which lies irrigated farm land of the Columbia Basin Irrigation Project.

At the 0 -degree radial, the 64- to 96-kilometer radius includes the towns of Ephrata and Soap Lake; also included is the southern end of Grand Coulee, a registered national landmark. The land is primarily range land, with some irrigated farm land around Soap Lake. The city of Moses Lake is in this zone at approximately the 20 -degree radial. 
Between the 20- and 90-degree radials is a large portion of 7 and planned for irrigation development as a part of the Columbia Basin Irrigation Project.

At approximately 70 degrees between the 72- and 96-kilometer radius, the 1 and is used for non-irrigated wheat production. Between the 90- and 120-degree radials and extending to the 120-kilometer radius, the land is used for non-irrigated wheat production. An exception is the area at the confluence of the Snake and Columbia rivers where private irrigation projects are under way. The 64- to 96-kilometer zone also includes the town of College Place and part of the city of Walla Walla. Moving west and south, the land is irrigated along the Walla Walla River and produces alfalfa and sugar beets. Land on both sides of the Columbia River below McNary Dam holds private irrigation projects totaling approximately 345 . sections ( 890 square kilometers). Between the 200- and 260-degree radials, the 1 and is very rugged and, for the most part, undeveloped. At the 260-degree radial, the Yakima Valley is entered with the city of Yakima at 270 degrees. Crossing the Umtanum Ridge and the Manastash Ridge, the Kittitas Valley is entered. This is an area of both irrigated and dry land farming and cattle production. At 330 degrees, a portion of the Wenatchee National Forest is found. 


\subsection{ECOLOGY}

\subsection{AQUATIC ECOLOGY}

3.1.1 Columbia River

The basic physical and chemical characteristics of the Columbia River are presented in Section 6.5.2. In addition, References 1 through 4 present much additional data on the ecological characteristics of the river, mainly in the Hanford to McNary Dam section.

Studies of the various aquatic organisms in the Columbia River, relating mainly to influence of the reactor operation, have been conducted for over 30 years. (5) Figure 3.1 is a simplified diagram of the food-web relationships in selected Columbia River biota and represents the probable major energy pathways.

Diatoms are the dominant algae in the Columbia River, usually representing over 90 percent of the population. The main genera include Fragilaria, Asterionella, Melosira, Tabellaria, and Synedra. Lentic forms that originate in the impoundments behind the upstream dams are dominant in the Hanford section of the river. Green algae and blue-green algae occur mainly in the warmer months, but in substantially fewer numbers than the diatoms.

Periphytic communities develop on suitable solid substrates wherever sufficient light occurs for photosynthesis. Dominant diatom genera include Melosira and Gomphonema; in spring and summer, luxuriant growths of the filamentous green algae Stigeoclonium and Ulothrix occur.

Emergent macrophytic vegetation is extremely sparse and is usually found in slack-water areas. Some rushes and sedges occur in flooded areas.

In the Hanford reach of the Columbia River, zooplankton populations are generally sparse. They are associated with benthic deposits in slack-water areas near the edge of the river with cladocerans being more abundant than capepods. ${ }^{(6)}$ Twenty-four species of Cladocera and Copepoda have been identified in McNary Reservoir. (7) This reservoir receives water from the Yakima, Snake, and Walla Walla rivers as well as from the Columbia, all of which may contribute to the zooplankton population. 


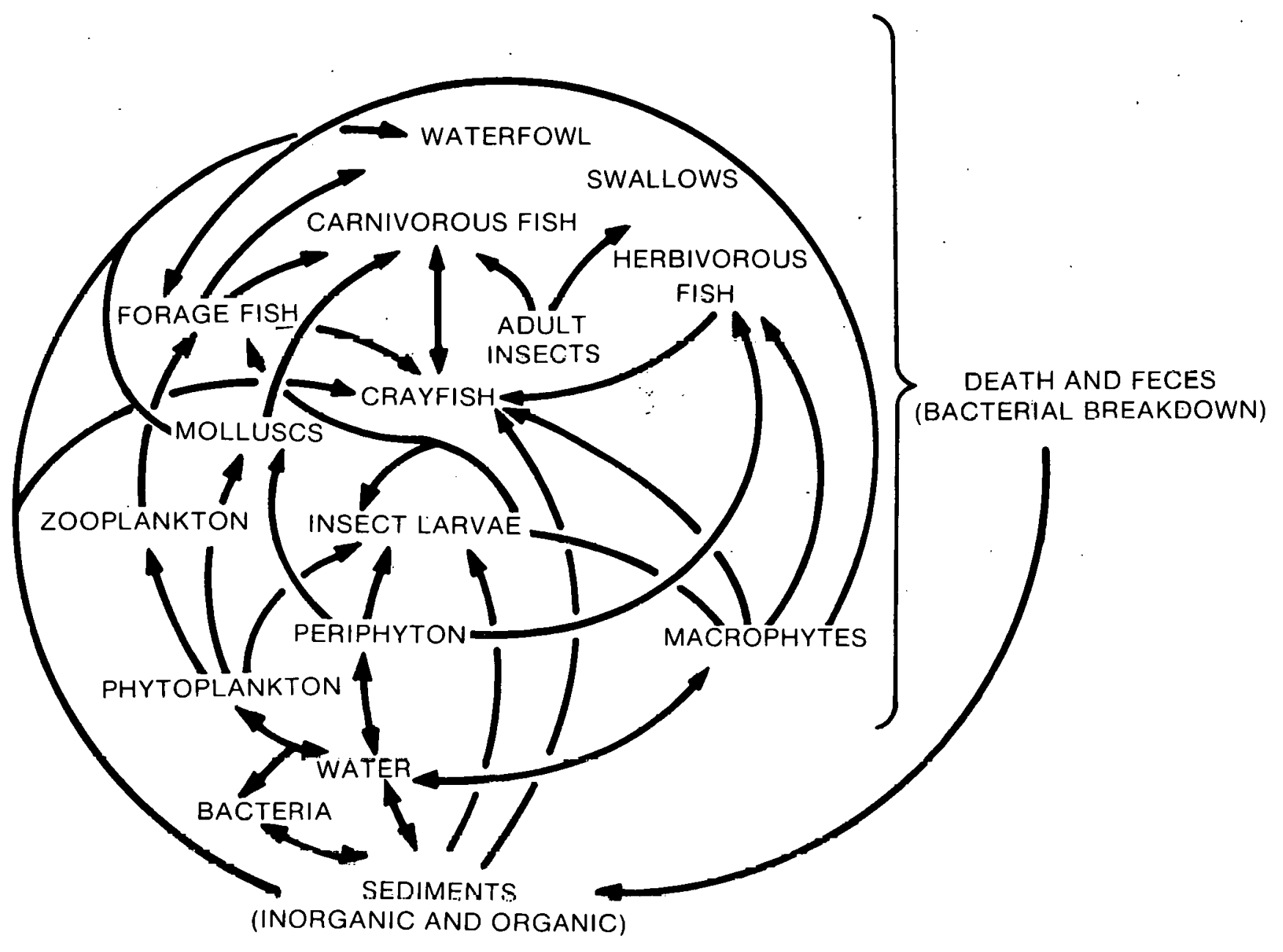

$\vee 7902-4.3$

\section{FIGURE 3.1}

FOOD WEB IN THE COLUMBIA RIVER 
Benthic biota consist of organisms which are either attached or closely associated with the substrate. Dominant organisms presently found in the free-flowing Columbia River include insect larvae, sponges, molluscs, flatworms, leeches, crayfish, and oligochaetes. The daily fluctuating water levels caused by the manipulation of flow by an upstream hydroelectric dam have destroyed a part of this fauna in the littoral zone. Thirteen benthic taxa were collected near Ringold in 1976. Midge fly (Chironomidae) larvae usually dominated the samples on all dates at all stations. Midge fly and caddisfly (Trichoptera) larvae accounted for over 95 percent of the individuals observed. However, in June 1976, black fly (Simuliidae) larvae represented 9 to 33 percent of the samples. No other benthic organism contributed more than a few percent of the community. Near 100-D Area, sponge was also a major component of the benthic community. (8) Peak numbers of insect larvae may be expected in fall or early winter as insect eggs hatch. Lowest numbers may be expected in the summer after adult emergence.

The fish species of greatest importance in the Hanford reach of the Columbia River are the salmon (Oncorhynchus) and steelhead (Salmo). These species live in fresh water during their early life stages, spend most of their life in the ocean, and return as adults to the river to spawn.

\subsubsection{Hanford Ponds and Ditches}

A number of ponds and ditches on the Hanford Site have received cooling water and other aqueous wastes (see Section 6.5.4). The ditches and ponds originally had sand substrates with a rapid rate of infiltration. Vegetation grows abundantly along them. The following information is taken primarily from Reference 9. Figure 3.2 illustrates. the typical food web in these ponds.

The ponds (except West Lake) are more richly populated with aquatic fauna in terms of variety and relative abundance than the streams. $U$ Pond, in particular; appears to have the most complete culture of aquatic animal life. West Lake, due lu its chemical makeup, has fewer numbers and a smaller variety of animal life, resembling the invertebrate populations occurring in Hanford streams. The varlety of invertebrates in 216-A-29 Ditch is also relatively. smaller and may have been limited by chemicals that are occasionally discharged into this slream. 


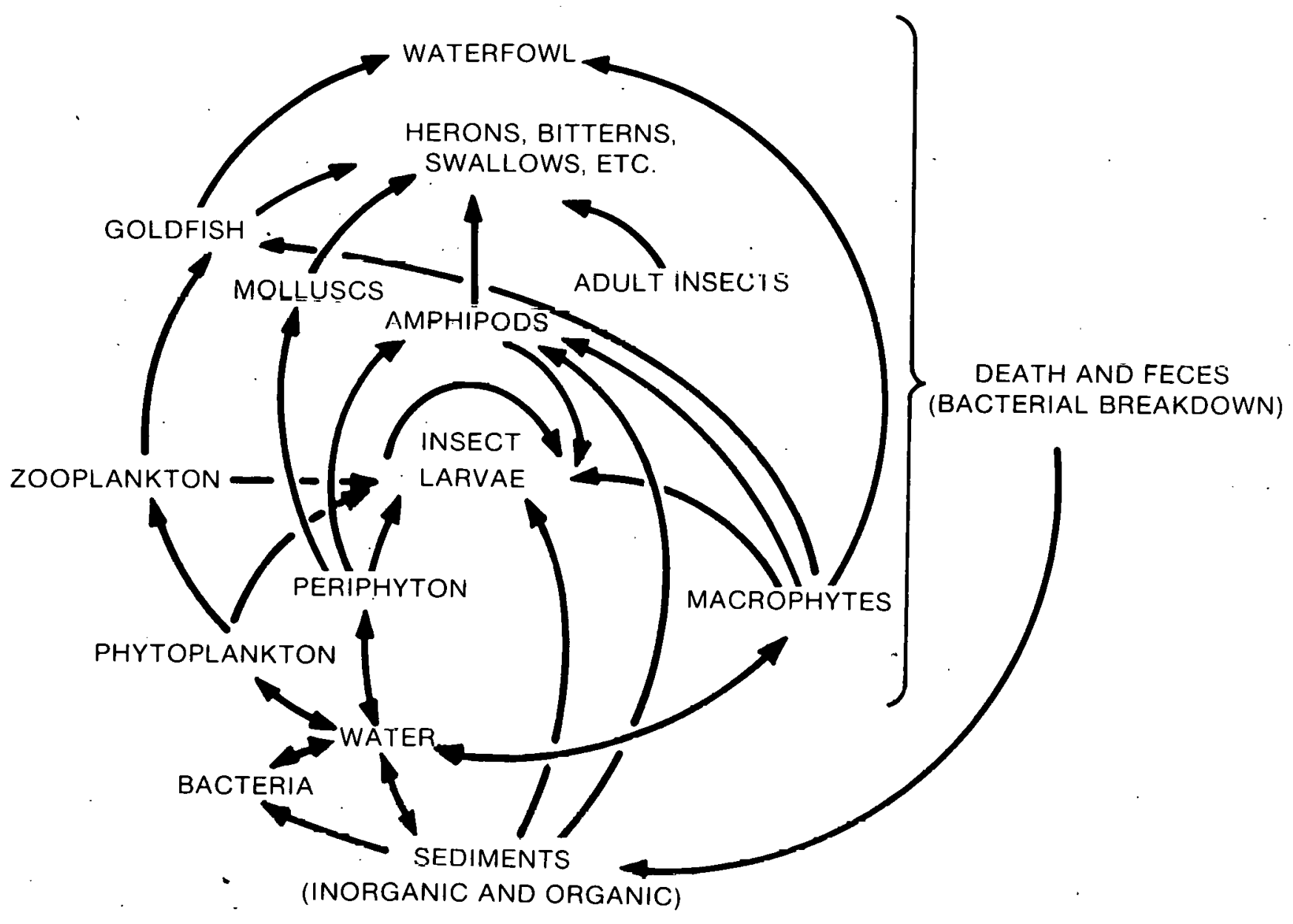

V7902-4.2

\section{FIGURE 3.2}

FOOD WEB IN GABLE MOUNTAIN POND AND U POND 
Goldfish populate Gable Pond, U Pond, B Pond, and 216-B-3 Ditch. Only $\cup$ Pond and Gable Pond have large populations of goldfish. Population estimates have been made only in $U$ Pond, showing a maximum production rate of about 40 kilograms per hectare per day. This falls within production ranges for suckers and carp for a number of North American fresh water systems. $(10)$

\subsubsection{Rattlesnake Springs}

Rattlesnake Springs, located on the ALE Reserve, is a permanent spring which begins from ground water seepage and is subsequently fed by small ground water springs along its course. It flows for approximately 2 to 3 kilometers, starting at about 12,000 cubic centimeters per second and disappears into the ground. The stream bottom is composed of sand and gravel, with rubble in some areas. The biotic communities in the stream are subjected to periodic flash floods in winter, depending upon weather conditions. Despite these floods, the stream supports a diverse flora and fauna.

\subsection{TERRESTRIAL ECOLOGY}

\subsubsection{Vegetation}

The most broadly distributed plant community on the Hanford Site is the sagebrush/cheatgrass/bluegrass association (Figure 3.3). The general paucity of herbaceous cover tends to favor invasion by tumbleweed, with or without fire.

The sagebrush/bitterbrush/cheatgrass community occupies the low elevations in the southeastern sector of the Hanford Site. Snowy eriogonum, a small shrub, is often locally abundant. The sagebrush/ bitterbrush/cheatgrass community occupies the sandiest soil short of dunes. Bitterbrush is an important forage plant for mule deer, especially in the fall and winter.

The cheatgrass/tumble mustard community occupies abandoned agricultural fields, especially in the vicinity of the 100 Areas. The vegetation type consists mostly of alien annual plants; i.e., cheatgrass and annual mustards. It has, over the past years, resisted invasion by 


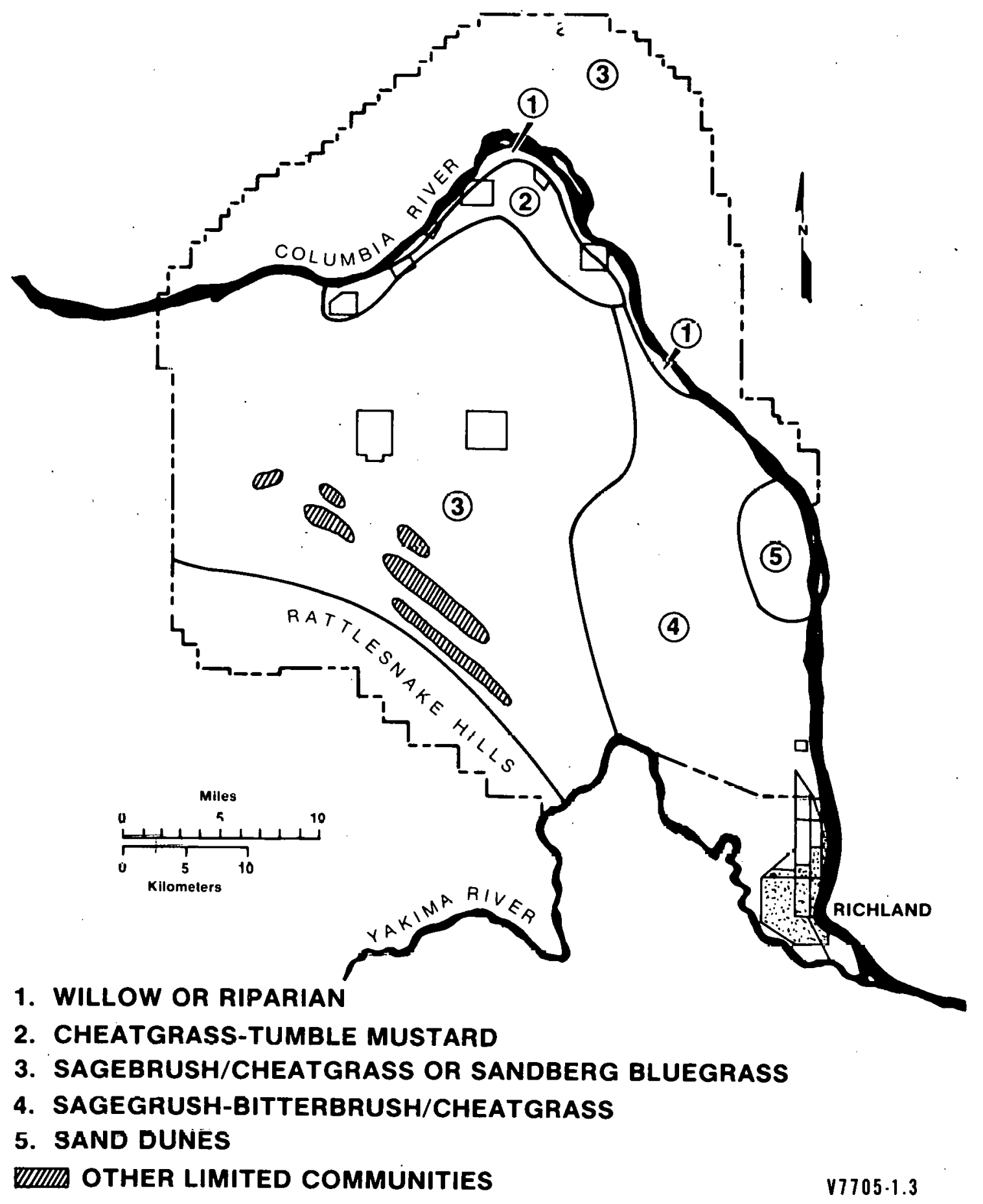

FIGURE 3.3

VEGETATION CLASSIFICATION AND DISTRIBUTION OF MAJOR VEGETATION TYPES ON THE HANFORD SITE 
native perennial grasses and shrubs and colonization by tumbleweed. Cheatgrass/tumble mustard communities in the absence of livestock grazing are effective in binding soil against wind- and water-disturbed soils.

Willow vegetation occurs along the banks of the Columbia River, around waste ponds in the 200 Areas, in abandoned agricultural irrigation ditches in the 100 Areas, and along permanent spring courses in the Rattlesnake Hills. Although the amount of acreage occupied by willow communities is small, their value to wildlife is large. Willows and associated deciduous trees, shrubs, and herbaceous plants provide food and nest sites for game and song birds, and summer forage and cover for mule deer.

The colonization of sandy soils in an arid environment is a slow process, especially if large areas are affected; i.e., by fire, and seed sources become severely reduced. The most efficient early invader of burned areas is Russian thistle or tumbleweed.

\subsubsection{Mammals}

A total of 27 mammal species (not including bats) is known to occupy the Hanford Site. (11) Most are sma11, inconspicuous, nocturnal creatures and accurate estimates of population densities, home range, and movement patterns have not been made for most species. A total of 12 bat species has also either been observed with in the Hanford confines or has a high probability of occurring here.

The mule deer and elk are the only big game mammals found on the Hanford Site. Most of the mule deer on the Hanford Site live along the Columbia River, with smaller concentrations near Gable Mountain and the 200 Areas, at Rattlesnake Springs, and on the Snively Ranch area in the Rattlesnake Hills. The elk only recently became established and have been observed oniy on the ALE Reserve.

The cottontail rabbit is the most abundant small game mammal, with small populations scattered throughout the site. The raccoon is probably the most abundant fur-bearing mammal, but is mostly confined to shore line areas of the Columbia River and waste ponds in the 200 Areas. Beaver and muskrats occur in back-water areas of the Columbia River, as well as in waste ponds and ditches in the 200 Areas. Mink occur along 
the Columbia River, while weasels are scattered throughout the Hanford area. The coyote is abundant on the Hanford Site, as compared to adjacent 1 and areas, although no accurate estimate of population density has been made. The bobcat and badger are present on the site, but few in number.

The jack rabbit is widely distributed on the site, however it is less abundant in the sagebrush/bluebunch/wheatgrass vegetation than in the sagebrush/cheatgrass and sagebrush/bitterbrush/cheatgrass communities. The jack rabbit is an important food item for coyotes and raptorial birds.

The porcupine is widely distributed over the site, but is especially abundant along the Columbia River. Porcupines occur in the 200 Areas and in the canyons and valleys of the Rattlesnake Hills.

Small mammals are abundant on the Hanford Site, particularly the Great Basin pocket mouse. Deer mice, ground squirrels, and pocket gophers are also locally abundant.

\subsubsection{Birds}

The chukar partridge is the most important upland game bird on the Hanford Site. Most of the population is concentrated on the ALE Reserve, especially the Rattlesnake Hills. Local populations are also present in the Gable Mountain area. Chinese ring-necked pheasants are present on the site, but are few in number. California quail are also present as scattered local populations along the Columbia River. Mourning doves, which are migratory birds, nest throughout the site during the spring months.

The Canada goose is the most important of nesting waterfowl on the Hanford Site; the nesting habitat is confined to islands in free-flowing reaches of the Columbia River. The Columbia River also provides a resting sanctuary for migratory flocks of ducks and Canada geese. At peak migratory periods, in excess of 70,000 birds (mostly mallards) may occupy the Hanford reach of the Columbia River. (12)

Raptorial birds use the Hanford Site as a refuge from human intrusions, especially during the nesting season. Trees around abandoned farms in the 100 Areas and around abandoned military installations provide nesting habitat for red-tailed hawks, Swainson's hawks, and great horned owls. Prairie falcon nests are located on Gable Butte and along 
Umtanum Ridge. (13) The sparrow hawk is the most abundant of the raptorial birds. The marsh hawk nests on the site (as does the burrowing ow 1), but the osprey is only an occasional visitor along the Columbia River. The golden eagle and the bald eagle are both winter visitors. The raptorial birds are of particular interest, because their ancestral ranges are being steadily reduced by human encroachment. Relatively large areas of uninhabited land, such as the Hanford Site, provide a nesting and foraging ground for raptorial birds.

\subsubsection{Insects on the 200 Areas Plateau}

Insects are an important, although incompletely understood, component within semi-arid ecosystems. Intensive studies have been conducted within sagebrush/bunchgrass and cheatgrass communities on the ALE Reserve. Results from these studies probably have little application to the 200 Areas plateau, since the community structure is very dissimilar. Insect studies near waste management facilities have concentrated on major groups; i.e., beetles and grasshoppers.

Darkling beetles are a dominant part of the insect community in most semi-arid regions of the west. Most occur throughout the year as long as favorable weather conditions permit. Dramatic changes in beetle abundance commonly occur within different communities and in different years.

Grasshoppers are also conspicuous components of the 200 Areas plateau ecosystem. Since they are predominantly herbivores and known for occasional population outbreaks, their presence in large numbers can exert a significant impact on energy flow and nutrient cycling patterns. A study of grasshopper populations inhabiting the B-C Cribs and Redox Pond sites of the 200 Areas plateau was conducted during 1974 and 1975. A total of 14 grasshopper species was collected from the B-C Cribs area and Redox Pond area. Population density was low during spring months, increased in late May, and reached a peak of 4 grasshoppers per square meter in early July. Data for individual species are included in an overall analysis for 200 Areàs plateau grásshopper populations. 


\subsubsection{Cold-Blooded Vertebrates}

The Hanford Site supports a variety of cold-blooded, vertebrate species. Reptiles (snakes and lizards) are most abundant, since they are physiologically adapted to a hot-arid environment, while amphibians require moisture in order to survive. Amphibians also require standing water (ponds, streams, etc.) in order to reproduce. Reptiles lay eggs which are encased in a hard shell making them resistant to dessication, while amphibians have no egg shell and must lay their eggs in a liquid environment in order to keep them mo ist.

Table 3.1 lists the reptiles and amphibians. which occur on the Hanford Site.

\subsection{RARE, THREATENED, AND ENDANGERED SPECIES}

Three endangered or threatened species of vascular plants are known to occur on the site: Balsamorhiza rosea; Erigeron piperianus; and Eriogonum thymoides. A11 occur on the ALE Reserve, rather than where waste management activities are conducted or planned. Allium robinsonii may occur in the gravel bars along the Columbia River, and is noted as a threatened species.

Reptiles and amphibians on the site are restricted to a few wide-ranging species, none of which can be classified as endangered, al though the desert night snake is seldom seen at Hanford.

Mammals on the site are not endangered at the species level, although their presence on the site may be in very small numbers. Mink and bobcat are examples of low-density species.

Birds are a different matter. The Hanford Site provides a refugium for several rare, threatened, or indeterminate species. Ihe Prairie falcon (Falco mexicanus) nests in several regions on the site, with the number of nesting pairs probably about six. This species is listed as a threatened species in the U. S. Department of the Interior Red Book.

The American peregrine falcon (Falco peregrinatus anatum) apparently does not nest on the site but in the neighboring regions, perhaps in small numbers. Species lacking specific data to attest to their status but considered to be possibly in danger (i.e., indeterminate) include: 


\section{TABLE 3.1}

AMPHIBIAN AND REPTILE SPECIES OBSERVED

ON THE HANFORD SITE

COMMON NAME

Amphibians

Great Basin Spadefoot

Western Toad

Pacific Treefrog

\section{Reptiles}

Sagebrush Lizard

Side-Blotched Lizard

Pigmy Short-Horned Lizard

Striped Whipsnake

Western Yellow-Bellied Racer

Gopher Snake

Desert Night Snake

Northern Pacific Rattlesnake
SCIENTIFIC NAME

Scaphiopus intermontanus

Bufo boreas

Hyla regilla

Sce loporus graciosus

Uta stansburiana

Phrynosoma douglassi

Masticophis taeniatus

Coluber constrictor

Pituophis me lanoleucus

Hysiglena torguata

Crotalus viridus
OCCURRENCE

U

$U$

U

c

U

0

C

C

R

C

$$
\begin{aligned}
& U=\text { Uncommon; } \\
& C=\text { Common; } \\
& R=\text { Rare } .
\end{aligned}
$$


(a) the Ferruginous rough-leg hawk (Buteo regalis); (b) the American Osprey (Pandion haliaetus carolinensis), only visitors; $(c)$ the Western burrowing owl (Speotyto cunicularia hypugaea); and (d) the long-billed curlew (Numenius americanus). The last two nest on the site in significant numbers, particulariy around the 200 Areas.

a. Long-billed curlews (Numenius americanus) nest in cheatgrass fields. This species is abundant around the 200 Areas, but its nesting density is highest around the 300 Area. The bird is a migrant to Washington and arrives at Hanford around March 18. It nests and raises young in the cheatgrass fields and sagebrush areas, and then. leaves the site to migrate southward in late June. During the March through June period, these birds are sensitive to human disturbance and will abandon their nests if disturbed. Care should be taken to keep personnel (vehicles and pedal traffic) out of nesting areas at all times.

The long-billed curlew is a bird of "undetermined" status and should, therefore, be afforded all possible protection.

b. The burrowing owl has been observed nesting on and adjacent. to the 200 Areas. This bird nests in burrows dug into the ground by other animal species (badgers and coyotes).

c. At least 6 pairs of Swainson's hawks (Buteo swainsoni) nest around the 200 Areas. These birds arrive on the Hanford Site by April 20 and stay until September. During this period, they lay eggs, raise young, and forage for food throughout the 200 Areas environs. 
Radiotelemetry studies conducted in 1976 revealed that the 200 Areas were used for hunting by these birds. Noises and traffic (foot travel and automobile) may be disruptive to the birds, but these factors can be controlled so that the impact will be negligible to thenesting Swainson's hawk. All hawks, owls, and eagles are protected by Federal law and many are listed as rare, threatened, or endangeredby state and Federal governments. The Swainson's hawk is not considered as rare or endangered by the Federal Government, but surveys conducted in Washington indicate that the Hanford Site is one of the most important nesting habitats in the state. 


\section{$4.0^{\prime}$ CLIMATOLOGY $(1,2)$}

The Hanford climate is mild and dry, with occasional periods of high winds. Summers are generally hot and dry; winters are not as dry and are relatively mild for this latitude. Air masses with source regions over the continent and over the Pacific Ocean reach the Hanford Site and exert their influence. Summerrs are sunny, warm, and dry, with several hot days. In the winter, frequent changes in the weather are caused by Pacific storm systems carried eastward by prevailing winds and arctic air masses moving southward from Canada.

The average maximum temperatures in July and January are $33.3^{\circ} \mathrm{C}$ and $2.8^{\circ} \mathrm{C}$. The average minimum temperatures for the same months are $16.1^{\circ} \mathrm{C}$ and $-6.0^{\circ} \mathrm{C}$. The average relative humidity varies from a low of 31.8 percent in July to a high of 80.4 percent in December. The minimum diurnal temperature in winter seasons ranges from $-32.8^{\circ} \mathrm{C}$ to $-5.6^{\circ} \mathrm{C}$, compared to diurnal maximum temperatures in summer seasons which vary from $37.8^{\circ} \mathrm{C}$ to $46.1^{\circ} \mathrm{C}$.

The Cascade Mountain Range to the west greatly affects the climate of the Hanford area. Hanford is in the rain shadow of these mountains, which results in relatively low rainfalls over the Hanford Site. By serving as a source of cold air drainage, the Cascade Mountains also have considerable influence on the wind and temperature regime at Hanford. This drainage (gravity) wind, plus topographic channeling, causes a considerable diurnal range of wind speeds during the summer at the HMS.

The HMS experiences high winds due to squall lines, frontal passages, strong pressure gradients, and thunderstorms. The site has experienced only one observed tornado and has not been known to be affected by hurricanes.

Average annual precipitation is about 160 millimeters. November, December, and January contribute 43 percent of the total; whereas July, August, and September contribute only 10 percent. A slight secondary maximum in precipitation occurs in early summer. About 39 percent of all precipitation during the months of December through February is in the form of snow. The maximum expected rainfall over the next 1,000 years is about 457 millimeters (a 3-fold increase for 1 year) (see Figure 4.1). 


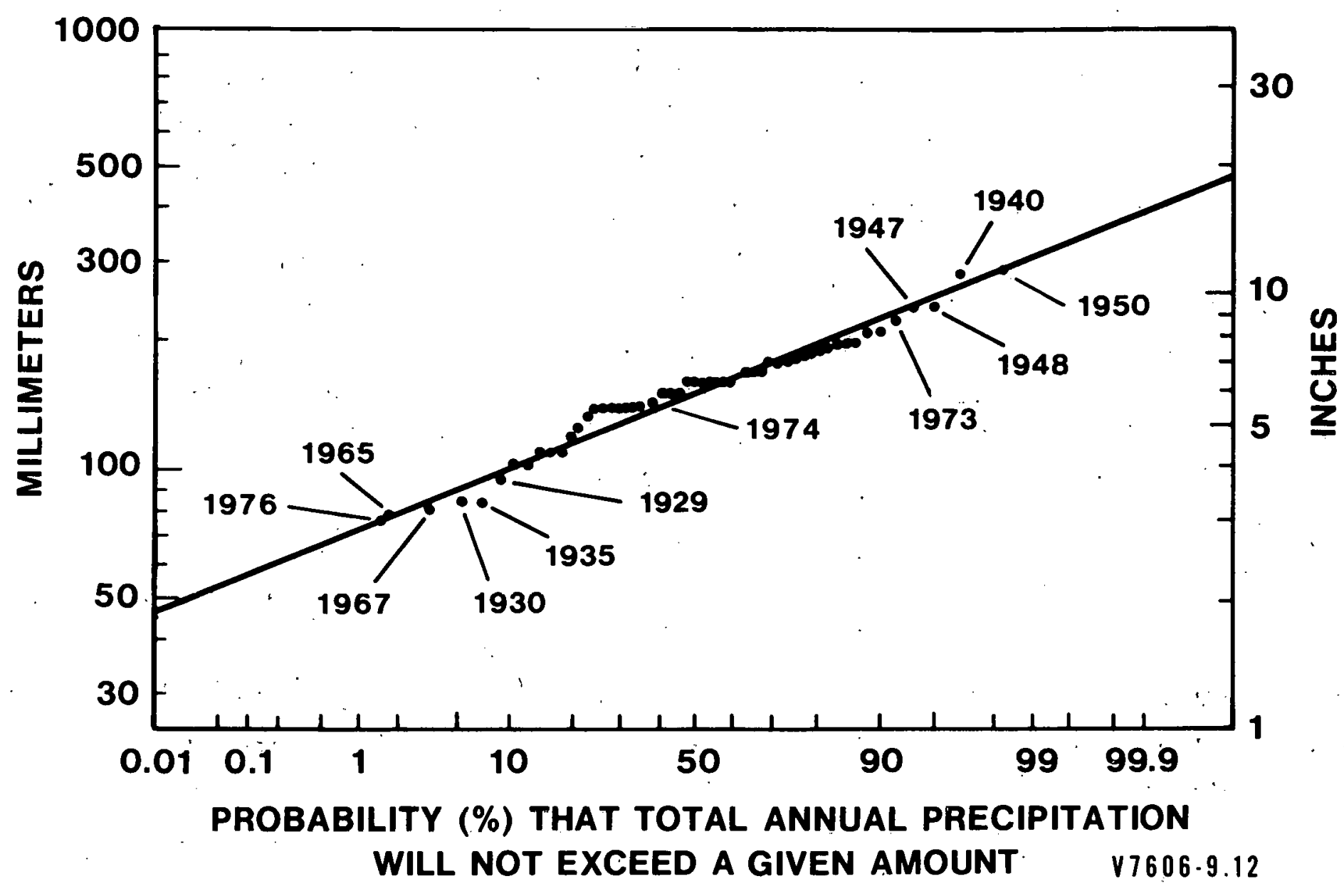

FIGURE 4.1

TOTAL ANNUAL PRECIPITATION PROBABILITY 
Mean monthly wind speeds range from about 14.5 kilometers per hour in the summer to 9.6 kilometers per hour in the winter. July hourly average wind speeds vary from a low of about 8 kilometers per hour in mid-morning to a high of 20.9 kilometers per hour in the late evening. The corresponding speeds in January have the same trend, but have less than a 1.6-kilometer-per-hour difference. The prevailing wind directions at the HMS are from the west-northwest through northwest (Figure 4.2). The strongest winds tend to be from the southwest. The highest observed peak wind gust at HMS was 115.8 kilometers per hour from the southwest. Winds with a peak gust of 64.4 kilometers per hour or greater have been observed on the average of at least once in every month of the year, although the winter months tend to have a higher frequency of high wind periods.

Relative humidity averages 75.7 and 31.8 percent in January and July, respectively, based on 15 recent years of record. The highest monthly average relative humidity was 90.5 percent in December 1950 , and the lowest average was 21.9 percent in July 1959. Relatively higher humidity values can be expected at locations near the Columbia River as the result of the increased availability of airborne water vapor evaporating from the river. Relative humidity values on the Wahluke Slope portion of the Hanford Site can be significantly higher as a result of agricultural irrigation operations conducted there. Relative humidity values can be expected to rise as one approaches the periphery of the Hanford area, again due to increased proximity to extensive agricultural irrigation operations.

Although the South Columbia Basin Irrigation District surrounding the Hanford area has increased to about 180,700 hectares during the past 23 years, no apparent increase in atmospheric moisture in terms of relative humidity has been detected at the HMS near the middle of the Hanford Site.

The preceding description of climatology based on the observations at the HMS can be taken as representative of the Hanford Site, although some local variations in climate may be expected as a result of the size of the site coupled with local topographical effects. No apparent climatological temperature differences exist among the low-level sites, al though observations show that simultaneous differences up to $5^{\circ} \mathrm{C}$ and $8^{\circ} \mathrm{C}$ can occur. In studies on the slopes of the ALE Reserve on the 


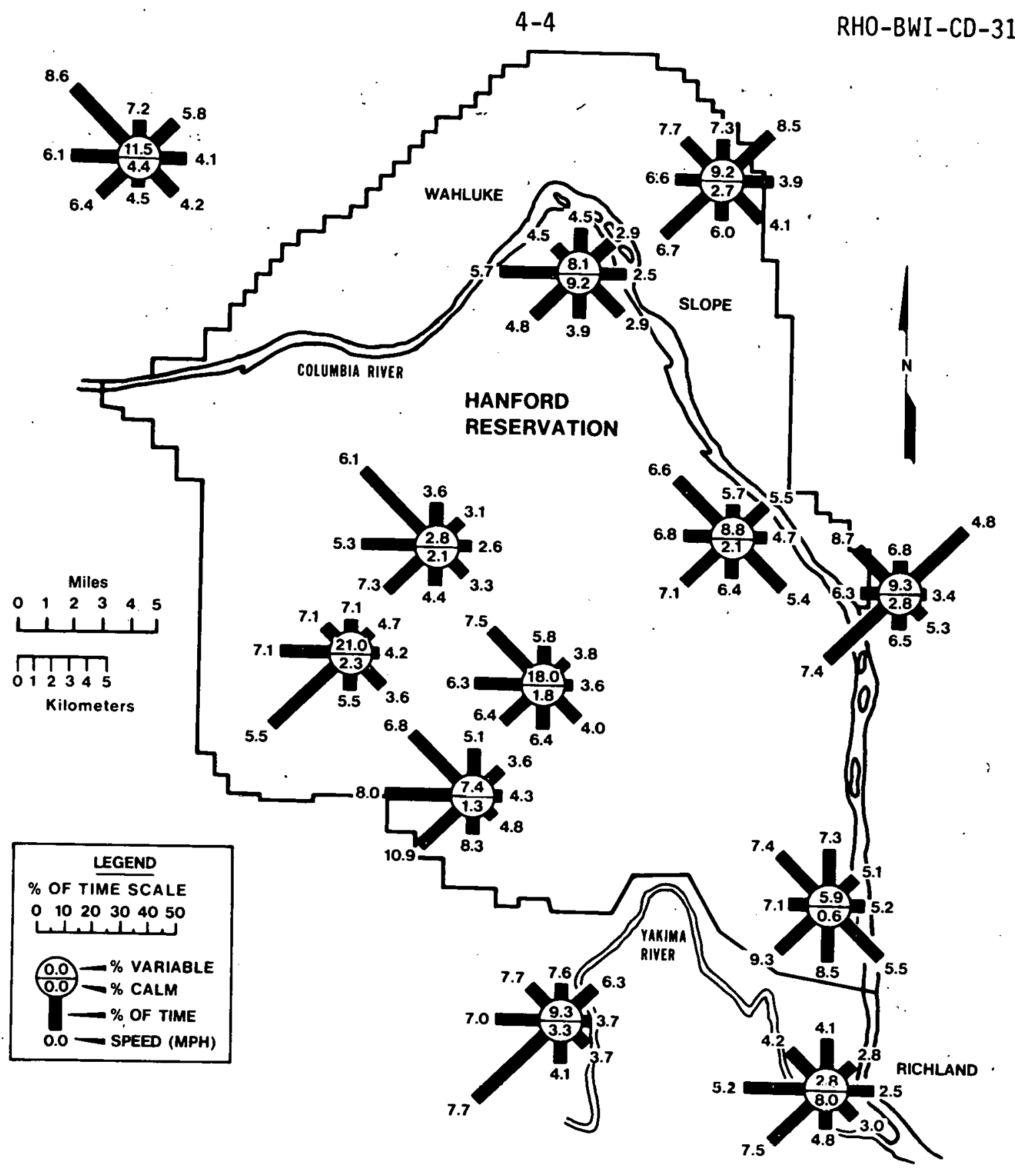

V7605.9.8

FIGURE 4.2

ROSE DIAGRAMS OF SURFACE WINDS AT HANFORD 
northeastern slope of the Hanford Site, average variations in temperature with change in elevation were found to closely follow the adiabatic lapse rate. This pattern is modified at higher elevations near the crest of the Rattlesnake Hills where the isotherms of minimum temperature indicate a well-defined nocturnal temperature inversion reaching to 180 to 300 meters above the valley floor. The inversion varies with season; intensifying in the spring and fall, diminishing in the winter and summer. 


\subsection{PHYSIOGRAPHY}

The Hanford Site is situated within the Columbia Plateau Physiographic Province as defined by Fenneman. (1) The province is characterized by the occurrence of a thick sequence of tholeiitic basalts and varies significantly in topographic expression as well as structure. The Columbia Plateau Physiographic Province is bordered by the Northern Rocky Mountains Physiographic Province to the north and east, the Basin and Range Physiographic Province to the south, and the Cascade and Pacific Border Physiographic Provinces to the west (Figure 5.1).

\subsection{COLUMBIA PLATEAU PHYSIOGRAPHIC PROVINCE}

The Columbia Plateau Physiographic Province can be subdivided into several smaller physiographic regions. The divisions are made as follows: (a) Columbia Basin section, sometimes referred to as the Columbia Plateau; (2) (b) the Blue Mountains section; and (c) the Harney-Snake River Plateau section.

\subsubsection{Columbia Basin Section}

The interior lowland portion of the Columbia Plateau, represented by a broad geologic and structural basin, is referred to as the Columbia Basin Section. The general topography of this region is shown in Figure 5.2. The major topographic relief is several east- to southeast-trending ridges on its western side. The Frenchman Hills, Saddle Mountains, Horse Heaven Hills, Rattlesnake Hills, Yakima Ridge, and Umtanum Ridge are surface expressions of anticlinal folds of Tertiary Columbia River basalts and sedimentary interbeds. Within the Hanford Site, the Rattlesnake Mountains, Yakima Ridge, and Umtanum-Gable Mountain Ridge represent an eastward to southeastward continuation of the ridge system. The Pasco Basin is one of several structural sub-basins within the Columbia Basin.

The Columbia Basin contains the Channeled Scabland that was formed at the close of Pleistocene glaciation. The Cordilleran Ice Sheet extended into northern Washington, but its maximum extent was $95 \mathrm{kilometers} \mathrm{north}$ of the Hanford Site. Ice-dammed lakes formed in northern Idaho and western Montana when ice lobes filled major drainage valleys. The 


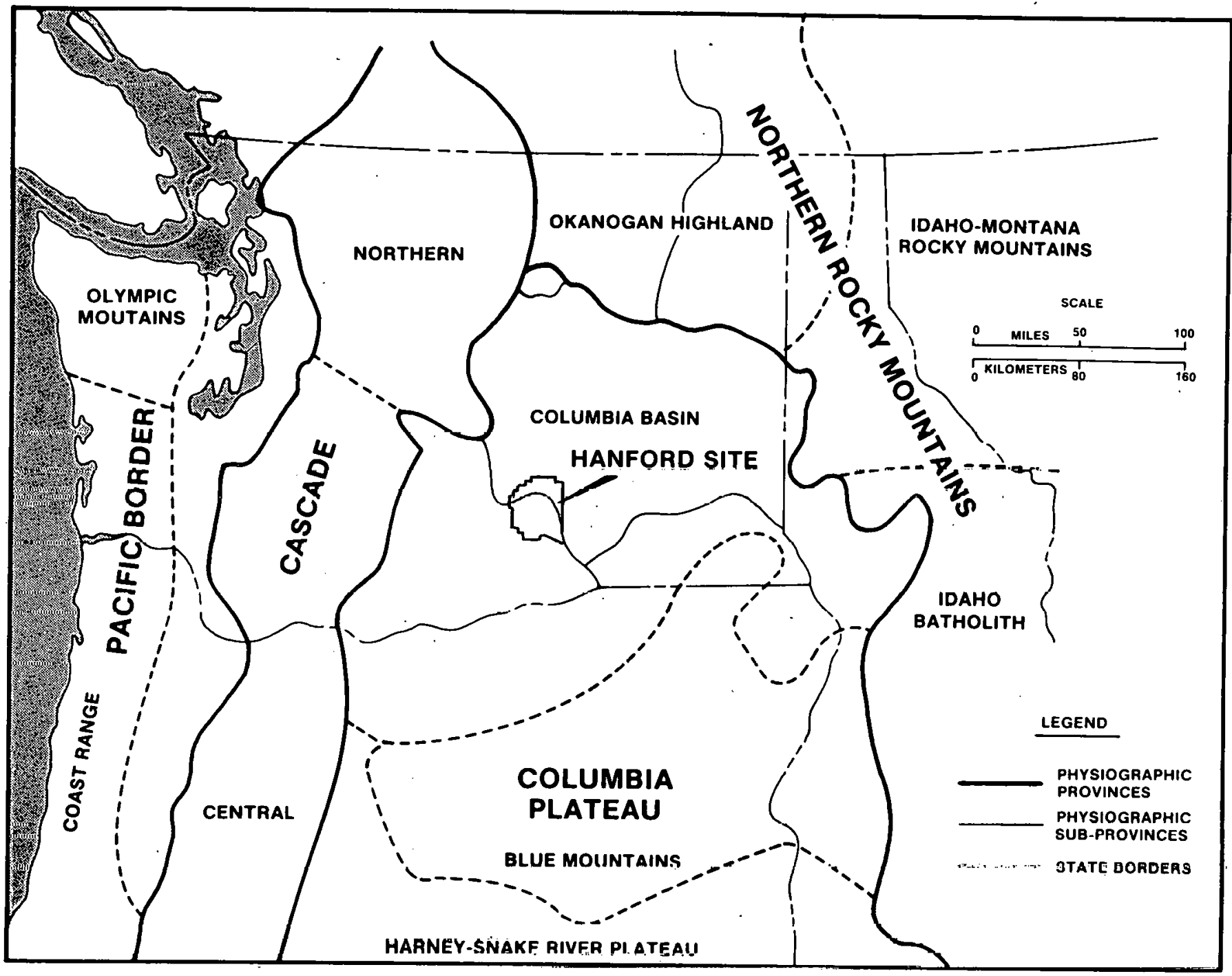

\section{FIGURE 5.1}

PHYSIOGRAPHIC PROVINCES 


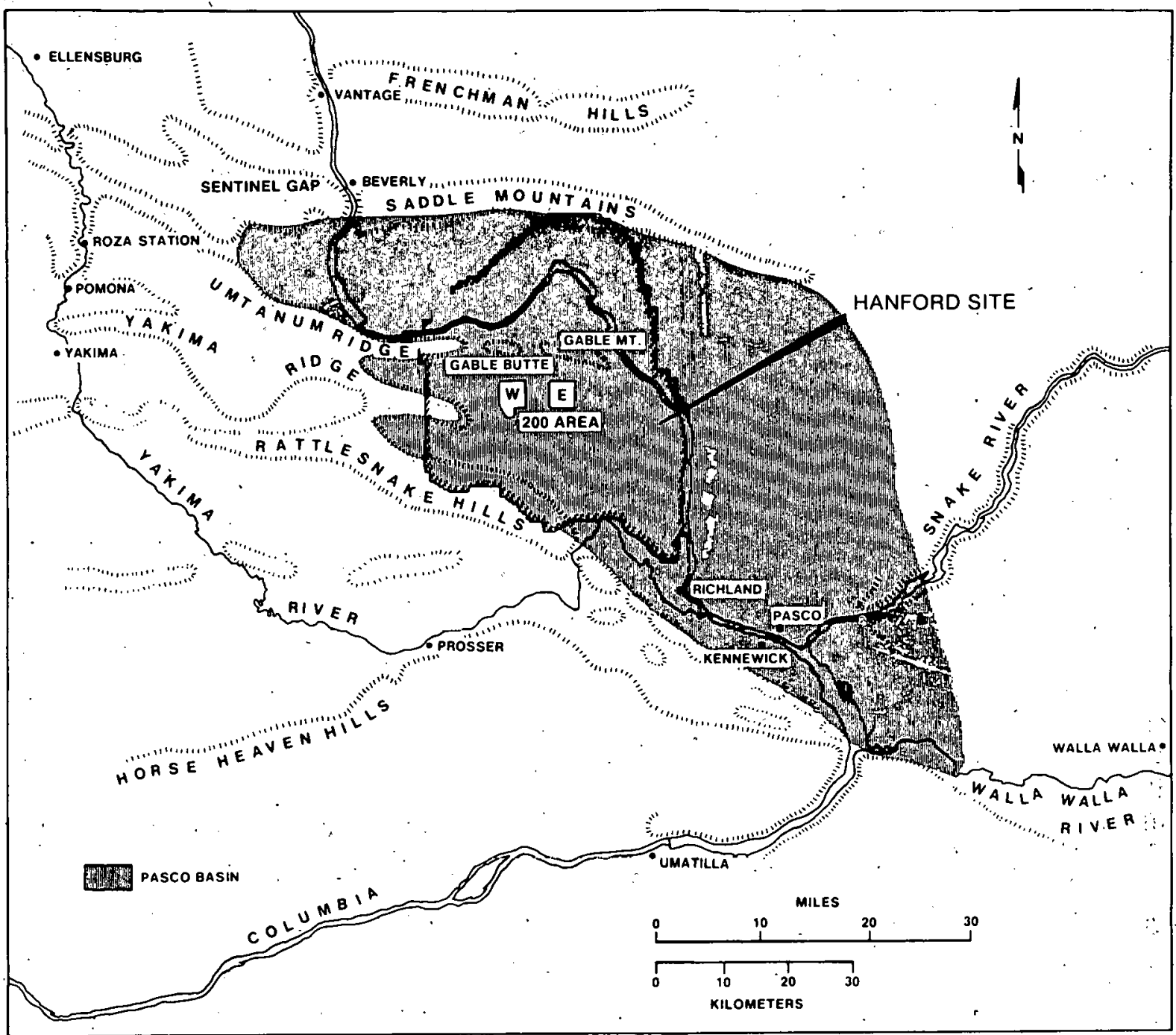

\section{F IGIIRE $5 . ?$}


failure of these dams resulted in multiple catastrophic flooding as the water spilled across the Columbia Basin Section. Maximum discharge through scabland channels has been estimated to be as much as 40 cubic kilometers of water per hour. (4) These floods eroded the basalt and post-basalt sediments forming large coulees and thick sequences of glaciofluvial sediments.

The eastern portion of the Columbia Basin is comprised of rolling hills mantled by the Palouse loess derived from degradation of Quaternary sediments from the west-southwest and northwest.

The Columbia Basin Section is drained by three major rivers. The Yakima River and its tributaries drain the southwestern portion, the Columbia River and its tributarles dratn the central and northern portion, and the Snake River and its tributaries drain the southeastern portion.

\subsubsection{B lue Mountains Section}

The 0choco, Blue, and Wallowa mountains all occur in this section and contain elevated plateau basalts similar to those of the Columbia Basin, as well as older rocks that have become exposed by erosion. Alpine glaciers were present in the Wallowa Mountains during the Pleistocene.

The structure and topography of this section have more in common with the Northern Rocky Mountains Physiographic Province than the Columbia Basin Section and lie mostly in northeastern Oregon. The mountains rise above the Columbia Basin Section to the north and the Harney-Snake River Plateau to the south. The Snake River crosses the eastern portion of this section through deeply entrenched gorges. The eastern portion is bordered by the Idaho Batholith Section, a section of the larger Northern Rocky Mountain Physiographic Province.

\subsubsection{Harney-Snake River Plateau Section}

The Harney region lies south of the Blue Mountains and is a high plain with little local relief except for volcanic craters mostly Quaternary in age. Internal drainage is characteristic of this region.

The Snake River Plateau region lies beyond a 320-kilometer radius from the Hanford Site. 


\subsection{NORTHERN ROCKY MOUNTAINS PHYSIOGRAPHIC PROVINCE}

The Northern Rocky Mountains are subdivided into the Okanogan Highlands Section, the Idaho-Montana Northern Rocky Mountains Section, and the Idaho Batholith Section.

\subsubsection{Okanogan Highlands Section}

This section lies north of the Columbia Basin Section of the Columbia Plateau Physiographic Province. The southern boundary is where the Columbia River Basalt Group laps onto the highland. It is made up of north-south-trending mountains between the Cascade Range Physiographic Province to the west and Idaho-Montana Section of the Northern Rocky Mountains Physiographic Province to the east. The region slopes toward the south with stream drainage into the Columbia Basin Section. The Okanogan Highlands molded by the Pleistocene glaciation have been highly dissected by fluvial erosion.

\subsubsection{Idaho-Montana Northern Rocky Mountains Section}

The mountains of this section of the Northern Rocky Mountains Physiographic Province have a north-northwest fabric and are drained by the Clark Fork River, Kootenai River, Pend Oreille River, and other tributaries of the Columbia River. The section was glaciated by both continental and alpine glaciers. The flood waters which scoured the Channeled Scabland of the Columbia Basin had their origin in this section when ice blocked the Clark Fork River and formed Glacial Lake Missoula.

\subsubsection{Idaho Batholith Section}

This section of the Northern Rocky Mountains Physiographic Province is defined geologically. It lies east of the Blue Mountains Section of the Columbia Plateau Physiographic Province and is drained by the Salmon and Clearwater rivers, which flow into the Snake River.

\subsection{CASCADE RANGE PHYSIOGRAPHIC PROVINCE}

The Cascade Range is bordered by the Columbia Plateau and Northern : Rocky Mountain Physiographic Provinces on the east and the Pacific Border Physiographic Province on the west. In Washington, the northern section 
of the range is referred to as the Northern Cascade Range. In Oregon, the Cascades are divided into the Western Cascade Range and the High Cascade Range, which extends into Washington. Mount Hood, Mount Rainier, and Mount Adams are prominent Pleistocene and younger strato-volcanoes of the High Cascades. Many glaciers are present on the high peaks of the Cascades. The Columbia River cuts across the Cascade Range at the Washington-Oregon border.

\subsection{PACIFIC BORDER PHYSIOGRAPHIC PROVINCE}

The Pacific Border Physiographic Province, as defined by

Fenneman, (1) includes the Puget-Willamette Lowlands Section and the Coast Range Section.

\subsubsection{Puget-Willamette Lowlands Section}

This lowland section extends from Eugene, Oregon to Vancouver, British Columbia. The northern part of this section which lies, in general, between the Cascade Range and the 0lympic Mountains, was modified by the Puget Sound Pleistocene ice lobe. The southern portion of the lowlands is drained by the Willamette River and contains fluvial and glaciofluvial valley fill.

\subsubsection{Coastal Range Section}

Included in this section are the 0lympic Mountains of Washington and the Coast Range of Oregon and southern Washington. The 0lympic Mountains are higher and more rugged, as well as wider than the Oregon Coast Range. Many alpine glaciers are found in the Olympic Mountains. 


\subsection{HYDROLOGY}

\subsection{REGIONAL HYDROGEOLOGY}

The Hanford Site is part of the Pasco Basin--a structural and topographic low within the Columbia Plateau Physiographic Province. The Pasco Basin. (Figure 5.2) is bounded by the Saddle Mountains to the north, the Umtanum and Yakima ridges to the west, the Rattlesnake and Horse Heaven hills to the south, and a broad regional monocline (known locally as the Jackass Mountain monocline) to the east.

The regional geology of the Hanford Site has been extensively studied and is discussed in Chapter 7.0. From a hydrologic standpoint, the area is composed of a series of confined aquifers (primarily sedimentary interbeds or interflow zones with in the Columbia River Basalt Group) overlain by an unconfined aquifer in the upper and middle Ringold Formation and overlying sediments of the Hanford formation (informal name). The hydrologic characteristics of the various stratigraphic horizons are summarized in Table 6.1.

Based upon interpretations from available geologic data, numerous lava outpourings emanated from extensive fissure systems and flowed across the Columbia Plateau during the Tertiary period. The viscous fluids covered the surrounding terrain and flowed into the regional low areas such as the Pasco Basin. As basining continued, thick sections of basalt accumulated within these low regions. Because of the geometry of the flows and the erosion or deposition of various sediments between the flows, there exists within these rock units several water=pruducing artesian aquifers; i.e., the Mabton-Priest Rapids aquifer in the Cold Creek area and the Frenchman Springs aquifer in the Quincy-0dessa area. Water recharged these aquifers about 14,000 years ago based on radiogenic age-dating using the radioactive carbon-14 technique.

During the late Tertiary Period, the number and size of fissure eruptions decreased markedly and finally ceased. Even though volcanic activity ceased, basining continued and was accompanied by a regional north-south compression. As a result of these compressional forces acting on the basalt rocks, a number of east-west-trending anticlinal ridges (e.g., Saddle Mountains) (Figure 5.2) were formed in the central 
TABLE 6.1

HYDROGEOLOGIC CHARACTERISTICS OF THE PASCO BASIN

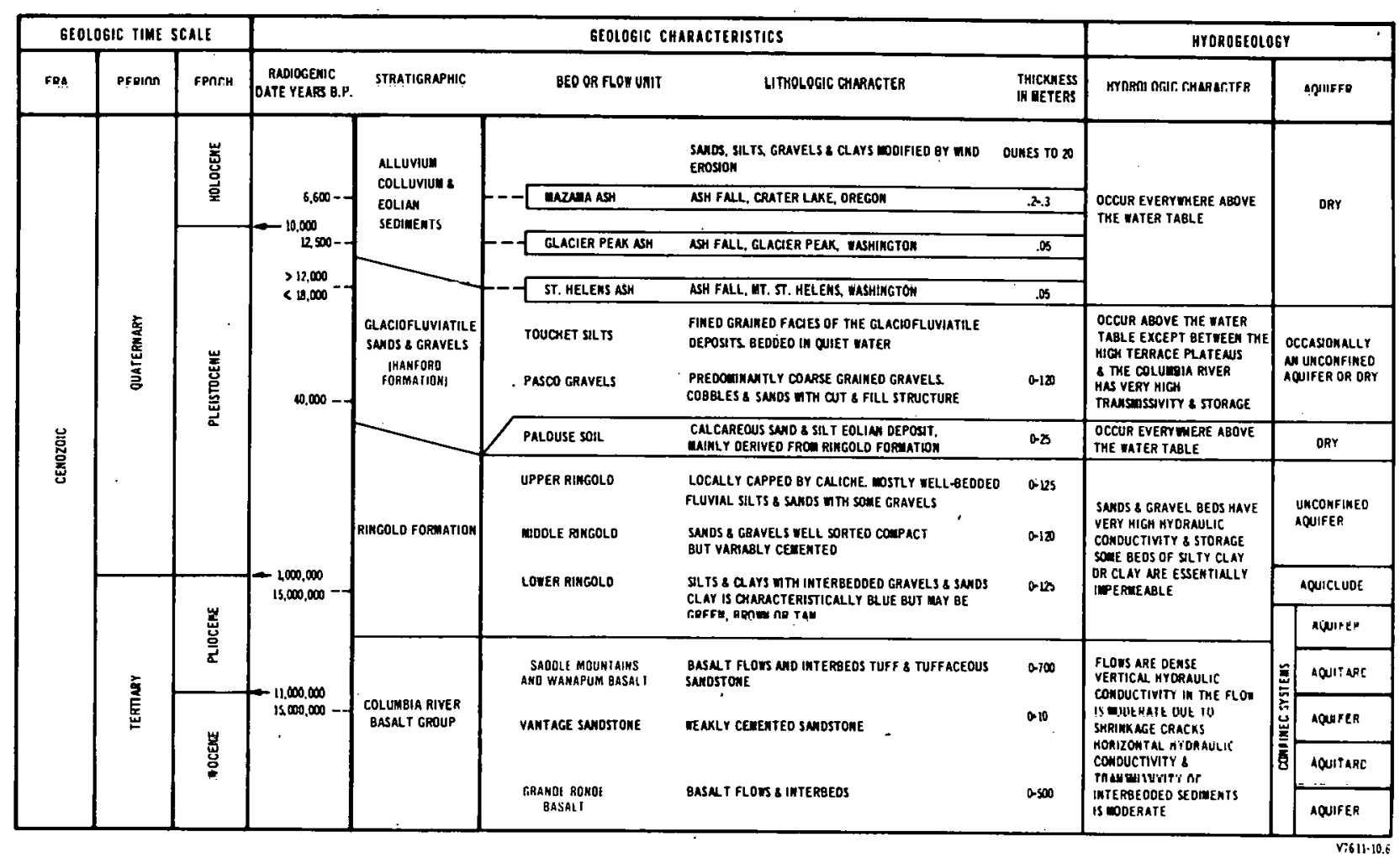


part of the Columbia Plateau. The formation of these ridges had a significant impact on the course of the Columbia River. Where the Columbia River was able to erode the basalt at the rate equal to or faster than formation of the anticlinal ridges, little change in the course of the Columbia River occurred. Where the ridges rose faster than the water was able to erode, the river was temporarily halted and lakes were formed. As basining continued, lacustrine and fluvial deposits continued to fill the Pasco Basin and covered previously deposited basalts. These sedimentary deposits comprise the Ringold Formation. The White Bluffs just east of the Columbia River and north of Richland represent the upper portion of the Ringold Formation.

The total thickness of the Ringold Formation in the Pasco Basin is about 300 meters. It is characterized by clay separating gravel lenses in the lower section, cemented gravels in the middle, and silts and sands in the upper part of the section. The Ringold sediments are well-to-poorly sorted and show a wide range of cementation. Locally, the coarse silts, sands and gravels possess high hydraulic conductivities and are capable of storing vast quantities of ground water. The clay and silty clay beds have very high porosity, but yield little or no water. These deposits are considered to be impermeable under hydraulic gradients of normal magnitude. The water table over the western portion of the Hanford Site occurs near the top of the Ringold Formation. In the eastern half of the site, the water table rises above the Ringold Formation and saturates the lower portion of the overlying Hanford formation.

The gravel zones in the lower Ringold Formation tend to form a local confined aquifer system. The upper part of the Ringold Formation and the overlying Hanford formation constitute the major unconfined aquifer underlying the Hanford Site.

The extent of the Columbia River down-cutting that took place during the Plio-Pleistocene Epoch is the primary factor that influences the unconfined aquifer. Significant paleochannels of very high hydraulic conductivity were formed as a result of this down cutting. The nature and location of the paleochannel have been studied using data from more than 1,500 wells drilled on the Hanford Site and from a gravity survey. $(1)$ 


\subsection{CONFINED AQUIFER SYSTEMS}

\subsubsection{Hanford Vicinity $(2)$}

The confined aquifer systems for the Hanford vicinity occur primarily with in the Columbia River Basalt; however, locally within basins the sediments overlying the basalt form part of the confined systems. The hydrology of the Columbia River Basalt has been studied since the 1890's, when Russe17 ${ }^{(3)}$ of the U. S. Geological Survey conducted a preliminary geologic investigation of central Washington to determine the possibility of developing artesian wells for irrigation water. As a result of his work, several producing wells were successfully drilled into different sub-laasins of the plateau.

Since then, extensive studies have been conducted by several investigators to define the hydrologic flow regimes present in the Columbia River Basalt. $(4,5,6)$ Ground water movement generally occurs within permeable interbeds or interflow zones which separate some of the basalt flows. These interbeds consist of fine sedimentary material deposited from an ancient stream or lake environment that had existed atop the basalt. A subsequent basalt flow covered the sediments. Interflow zones of vesicular rock occurring along a flow top or interconnected tractures resulting from rapid cooling of the bottom of the flow may also produce permeable regions for ground water movement.

The central volume of most basalt flows is quite dense, having very low permeabilities. Fractures, originating from the cooling of the initial molten rock or subsequent structural deformation, control the hydraulic interconnection occurring between basalt units. In many instances, secondary mineralization has effectively sealed these fractures from further ground water movement. The hydraulic separation of individual water-bearing strata is apparent when the water levels at the top and bottom of some basalt flows are compared. Figure 6.1 gives an example of isolation of various aquifers within the basalt for a well in the Odessa, Washington area. 


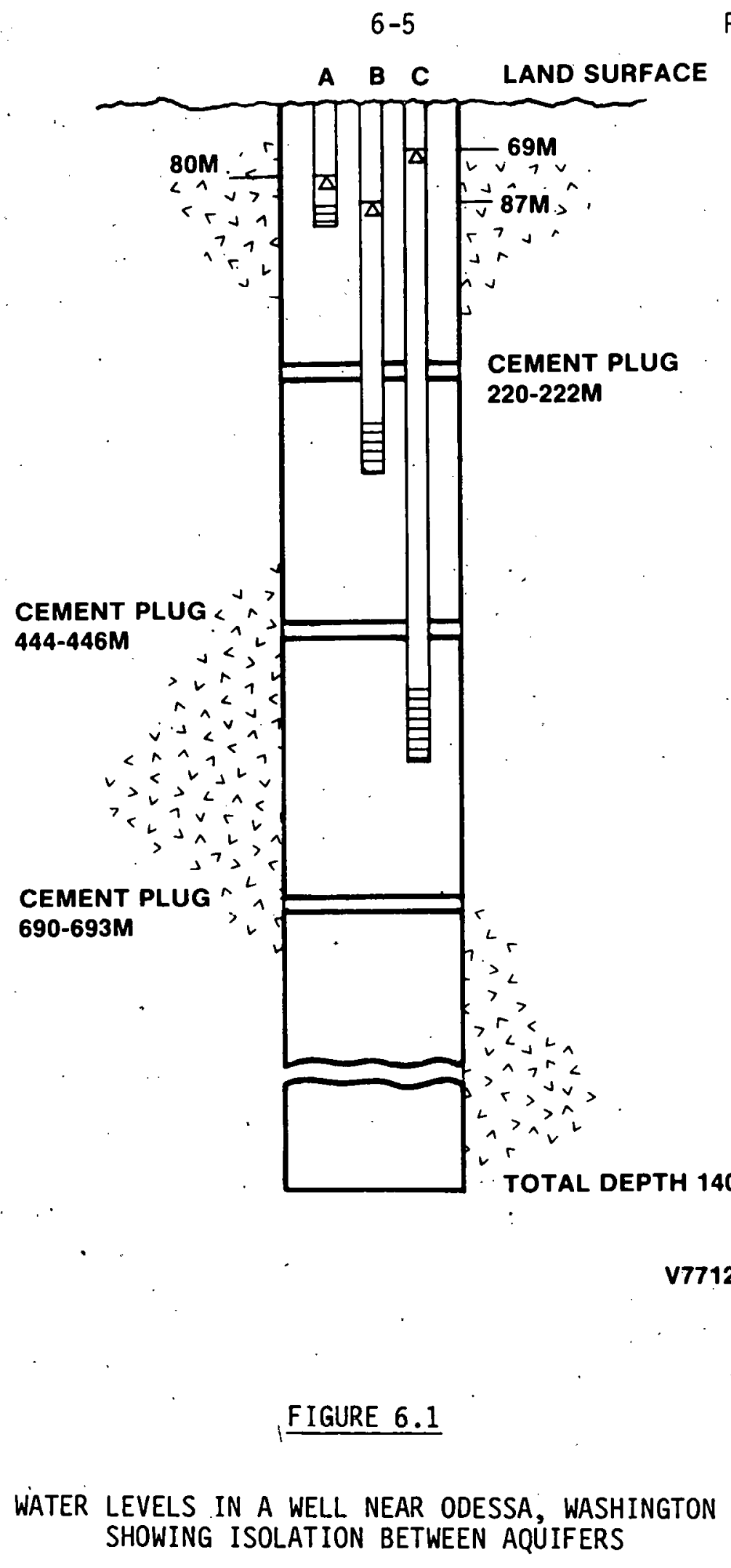

RHO-BWI -CD-31

V7712-7.2

SHOWING ISOLATION BETWEEN AQUIFERS 
Ground water movement does occur along some zones within the basalts. However, that portion of the basalt under consideration for the storage of radioactive waste is the dense, thick, central volume of certain flows having little, if any, known hydraulic contact with the regional aquifers. Most investigators conclude that ground water does move in the horizontal plane along the interflow zones and not in the dense central volume of the flow. Any vertical flow occurring through fractures is quite limited, having been determined in one area to be less than $10^{-7}$ meters per day. (7)

Using actual pumping data from the Odessa area, the storage coefficient within the interflow zones of the Columbia River Basalt has been estimated to vary between $2.5 \times 10^{-3}$ and $6.5 \times 10^{-3}$. (8) (The storage coefficient approaches the compressibility of water with in the dense central positions of a basalt flow.) Using age-dating information and changes in water levels, most investigators conclude that ground water is being withdrawn from storage and that little or no recharge is occurring.

\subsubsection{Hanford Site}

Confined aquifers beneath the Hanford Site include permeable units within the lower member of the Ringold Formation and sedimentary interbed and interflow contacts within the Yakima Basalt Subgroup.

Recharge to the confined aquifers occurs from: (a) precipitation; (b) stream runoff; and/or (c) infiltration from an overlying unconfined aquifer.

Figure 6.2 shows the regional potentiometric surface within the upper confined aquifer systems as defined from available core and piezometric well data. Ground water moves down-gradient, perpendicular to equipotential lines, from areas of recharge and discharge ultimately to the Columbia River. Information available from existing piezometers indicates that for most of the Hanford Site only small hydraulic head differences occur between aquifers of the upper and lower confined systems. Regional movement of ground water, therefore, is anticipated to have a similar pattern, as shown in Figure 6.2, for all confined systems. 


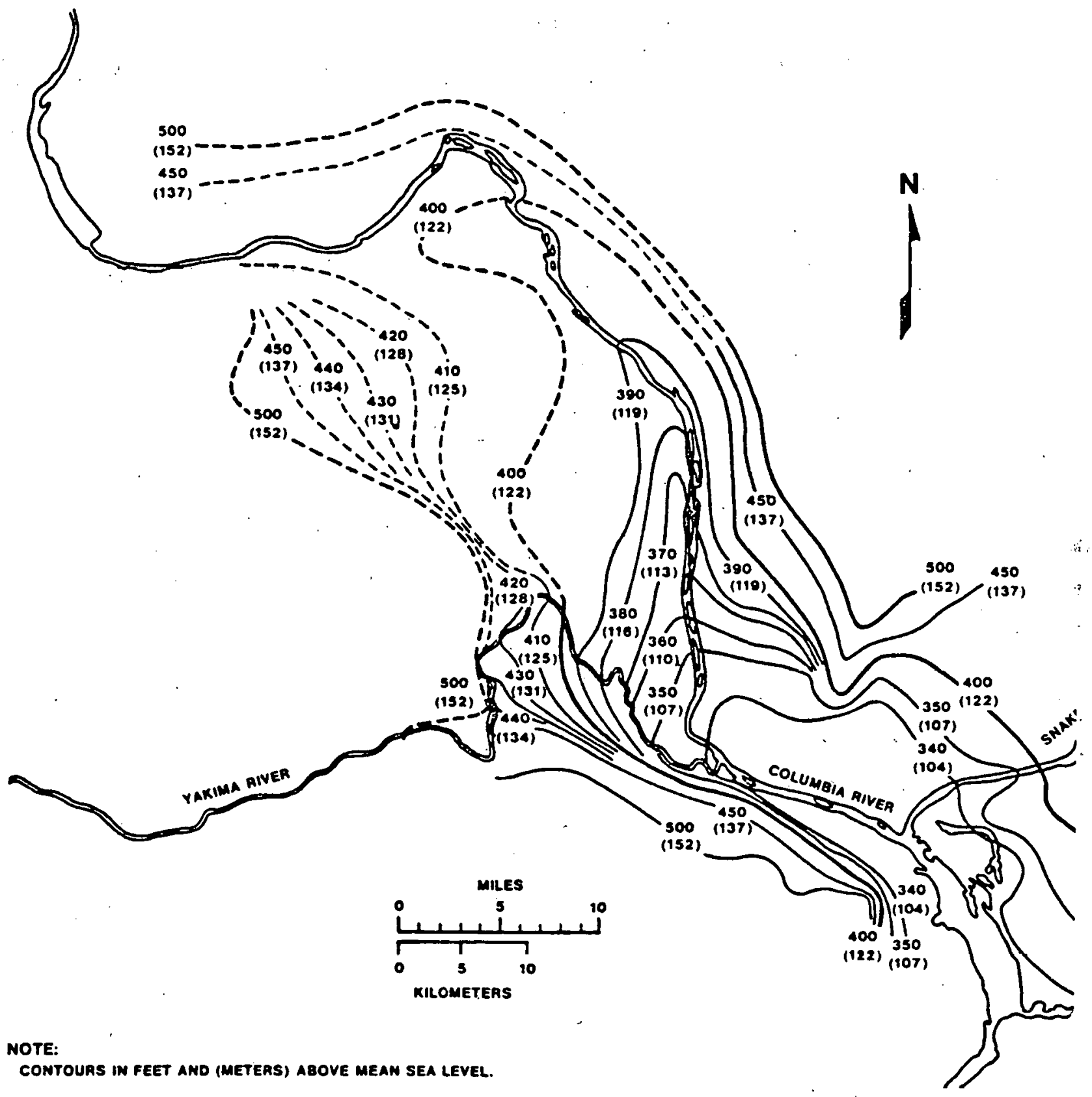

NOTE

FIGURE 6.2

PASCO BASIN UPPERMOST CONFINED AQUIFER POTENTIAL MAP 
Existing information concerning hydraulic properties of various geologic units within confined aquifer systems is shown in Table 6.2. Properties listed for the upper confined system were obtained by in-field aquifer tests, while values listed for basalts within the lower confined system were determined from laboratory studies and drill-stem tests.

As shown in Table 6.2, values for hydraulic properties generally range higher for aquifers within the upper confined flow system. Basalt interflow zones also tend to have higher hydraulic property values in comparison to other confined aquifers.

Only limited information is available concerning the chemical quality of ground water within confined systems at Hanford. Available information, however, suggests that, within the discharge region of the various confined aquifer systems (i.e., eastern third of Hanford), water chemistries are quite uniform within individual aquifers. The uniformity of chemical quality within individual aquifers in this region is attributed to the influence of geochemical-mineral equilibria relationships which are present. The chemical-type classification for aquifers within the discharge region is given in Table 6.2.

Within recharge and lateral flow regions of confined systems, considerable variability is evident within individual aquifers. The chemical variability is primarily related to differences in: residence time of ground waters; (b) corrosibility of existing geologic materials; and $(c)$ sources of recharge waters.

\subsection{UNCONF INED AQUIFER SYSTEM}

The unconfined aquifer consists of sand and gravel deposits of both the Hanford and Ringold formations. Since these materials are very heterogeneous, greater lithologic differences of ten appear within a given bed than between beds. The water table represents the top of the unconfined aquifer at any given time (Figure 6.3). The aquifer bottom is either basalt bedrock or silt and clay zones of the Ringold Formation (Figure 6.4). The aquifer bottom has been determined using information from hundreds of wells drilled at Hanford. The hydraulic characteristics 
TABLE 6.2

HYDRAULIC PROPERTIES OF THE CONFINED AQUIFER SYSTEMS AT HANFORD

HYDRAUL IC CONDUCTIVITY

(feet/day)

UPPER CONF INED SYSTEM

Lower Ringold Formation

Saddle Mountains Interflows

LOWER CONF INED SYSTEM

Wanapum Interflows

Grande Ronde Interflows
$7-11$ GROUND WATER CHEMICAL TYPE
$8-12$

$\mathrm{Na}-\left(\mathrm{HCO}_{3}\right)$

$1-10^{-5}$ 


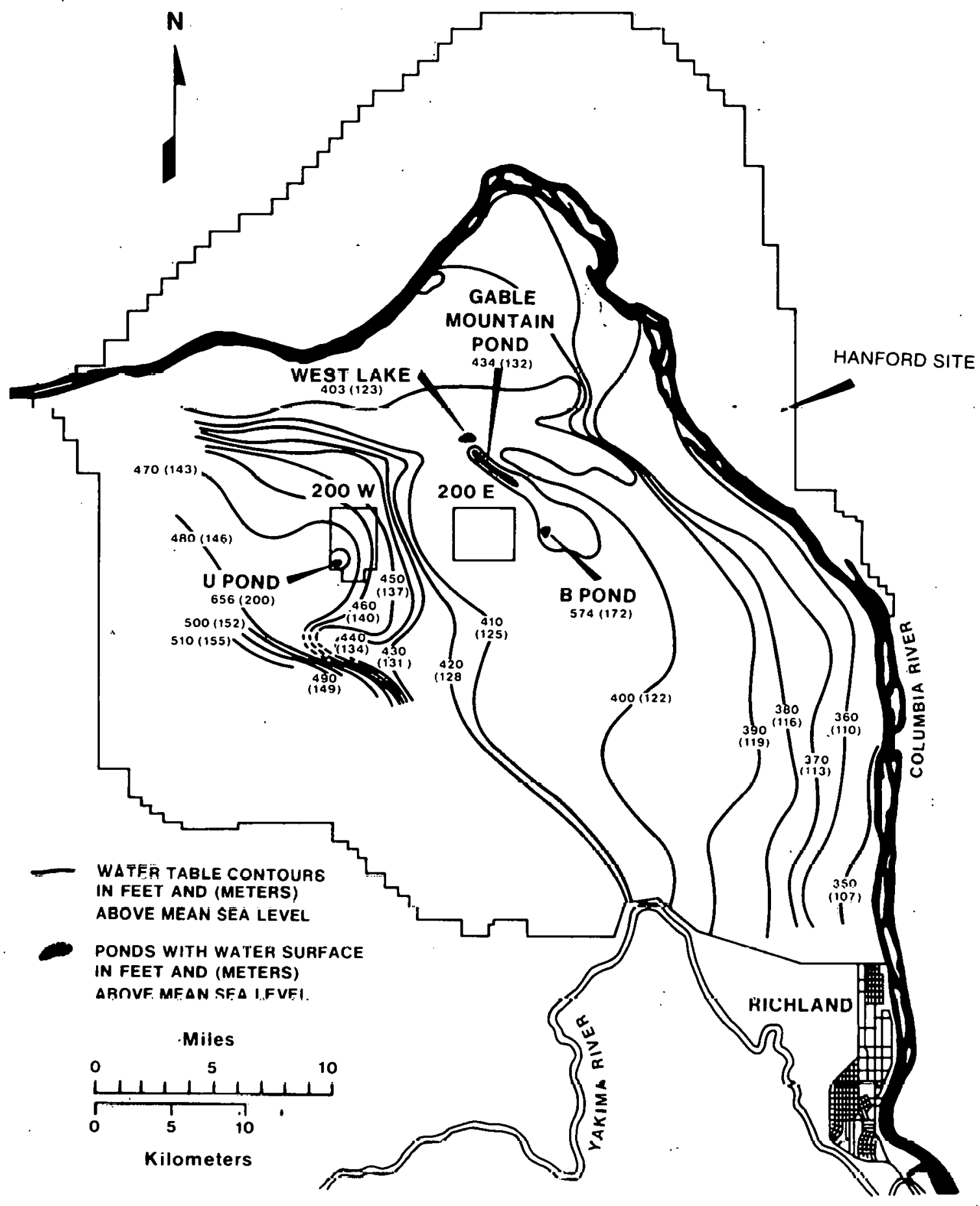

v7611-10.2

FIGURE 6.3

HANFORD SITE WATER TABLE MAP - DECEMBER 1976 


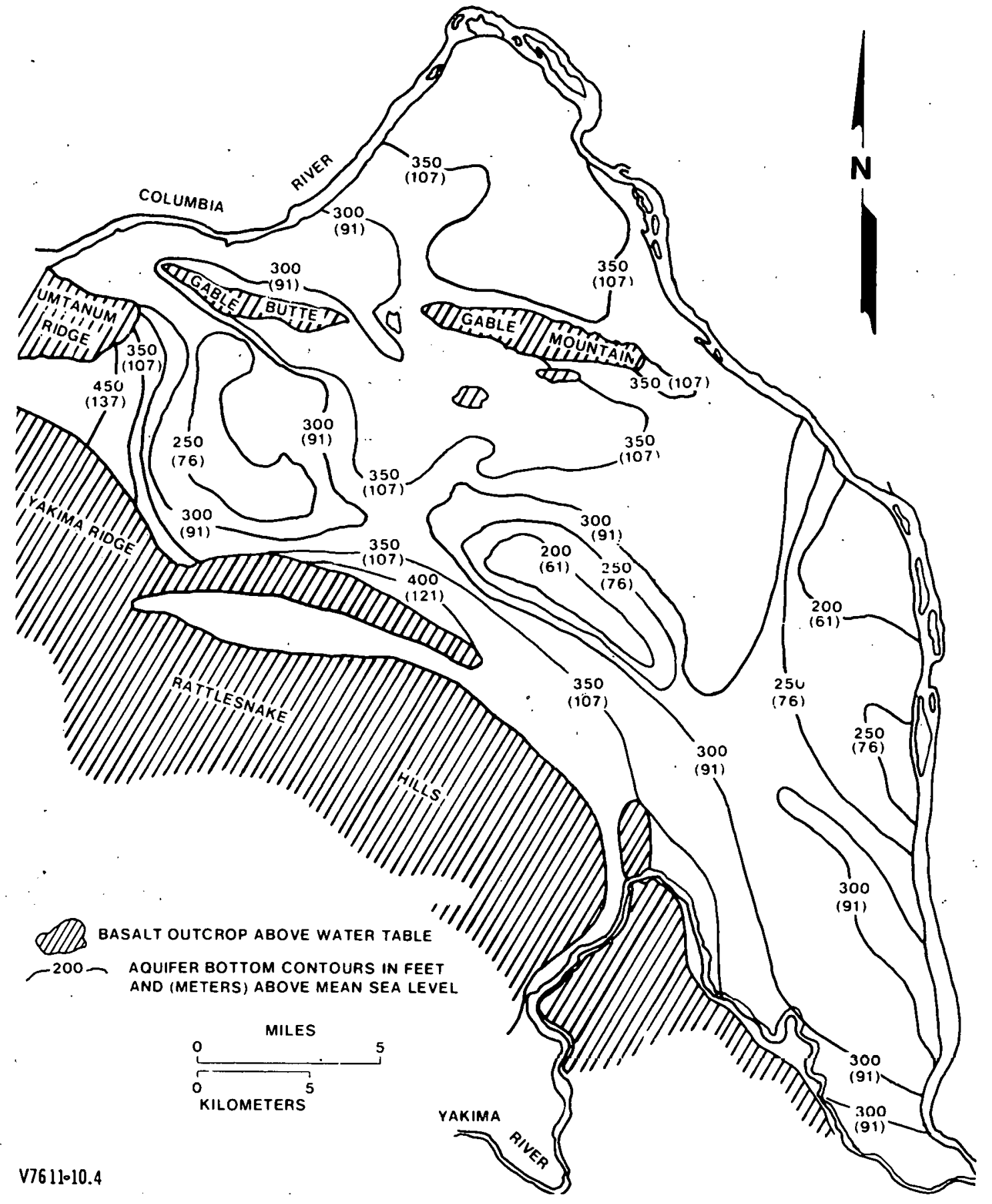

FIGURE 6.4 
of the unconfined aquifer are quite variable and are summarized in Table 6.3. The storage coefficient is not sufficiently well known to plot its areal distribution; however, as a result of extensive pump testing and from geologic studies, a map was developed from the vertically averaged hydraulic conductivity distribution for the unconfined aquifer system (Figure 6.5). A zone of high hydraulic conductivity is situated between Gable Butte and Gable Mountain and continues through the middle of the Hanford Site.

The Rattlesnake Hills, Yakima Ridge, and Umtanum Ridge to the west and southwest (Figure 5.2) are low-permeable boundaries. Gable Mountain and Gable Butte, as well as other small areas of basalt, crop out above the water table and distort ground water flow. The Yakima River recharges the unconfined aquifer along its reach from Horn Rapids to Richland. The Columbia River represents a hydraulic discharge boundary for the aquifer. Ground water flow and bank storage are affected by seasonal river'stage fluctuations from 1.6 to 4.8 kilometers inland from the Columbia River.

The flow pattern that originally prevailed in the unconfined aquifer prior to waste discharges was primarily to the east and northeast with discharge into the Columbia River. ${ }^{(9)}$ Natural recharge occurs in the Cold Creek and Dry Creek valleys along the margin of Rattlesnake Hills and Yakima Ridge. Ground water flow appears to be distorted by a buried extension of Yakima Ridge, which parallels Rattlesnake Hills at a distance of about 3.2 kilometers.

As a result of waste disposal activities at Hanford, the unconfined ground water system has been modified by the imposition of three synthetic flow systems: (a) the 200 West Area; (b) the 200 East Area; and. (c) Gable Mountain Pond (Figure 6.5).

The 200 West Area receives approximately one-third of the liquid disposed to the ground at the Hanford Site. Based upon piezometer measurements, ground water from this area appears to under-flow that of the 200 East Area. (10) 
TABLE 6.3

SELECTED HYDRAULIC PROPERTIES OF THE UNCONFINED AQUIFER SYSTEM

INTERVAL TESTED

Hanf ord formation

Hanford and Ringold

formations

Ringold Formation
HYDRAULIC CONDUCTIVITY

(feet/day)

$500-20,000$

$100-1,000$

$1-\quad 200$
STORAGE

COEFF ICIENT

$0.05-0.3$ 
VEERTICAL EXAGGERATION $=64$ TIMES

XXX EQUIPOTENTIAL LINES IN FEET AND (METERS)

- FLOW SYSTEM DIVIDES

GROUNDWATER FLOW DIRECTION

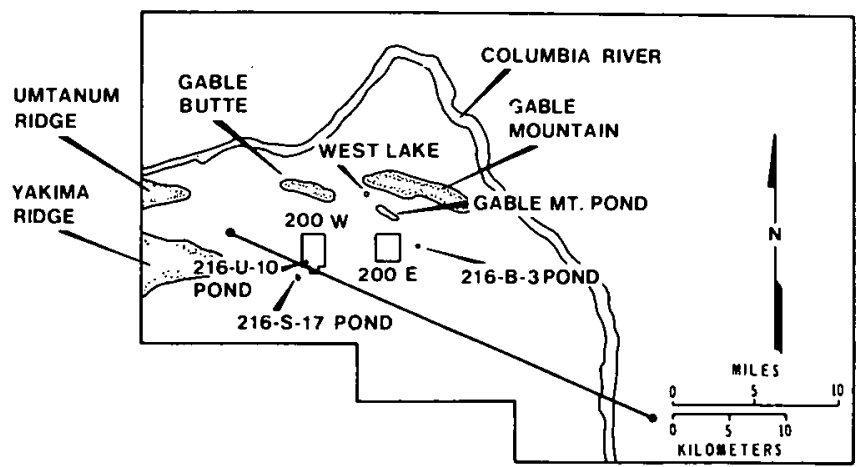

INDEX MAP

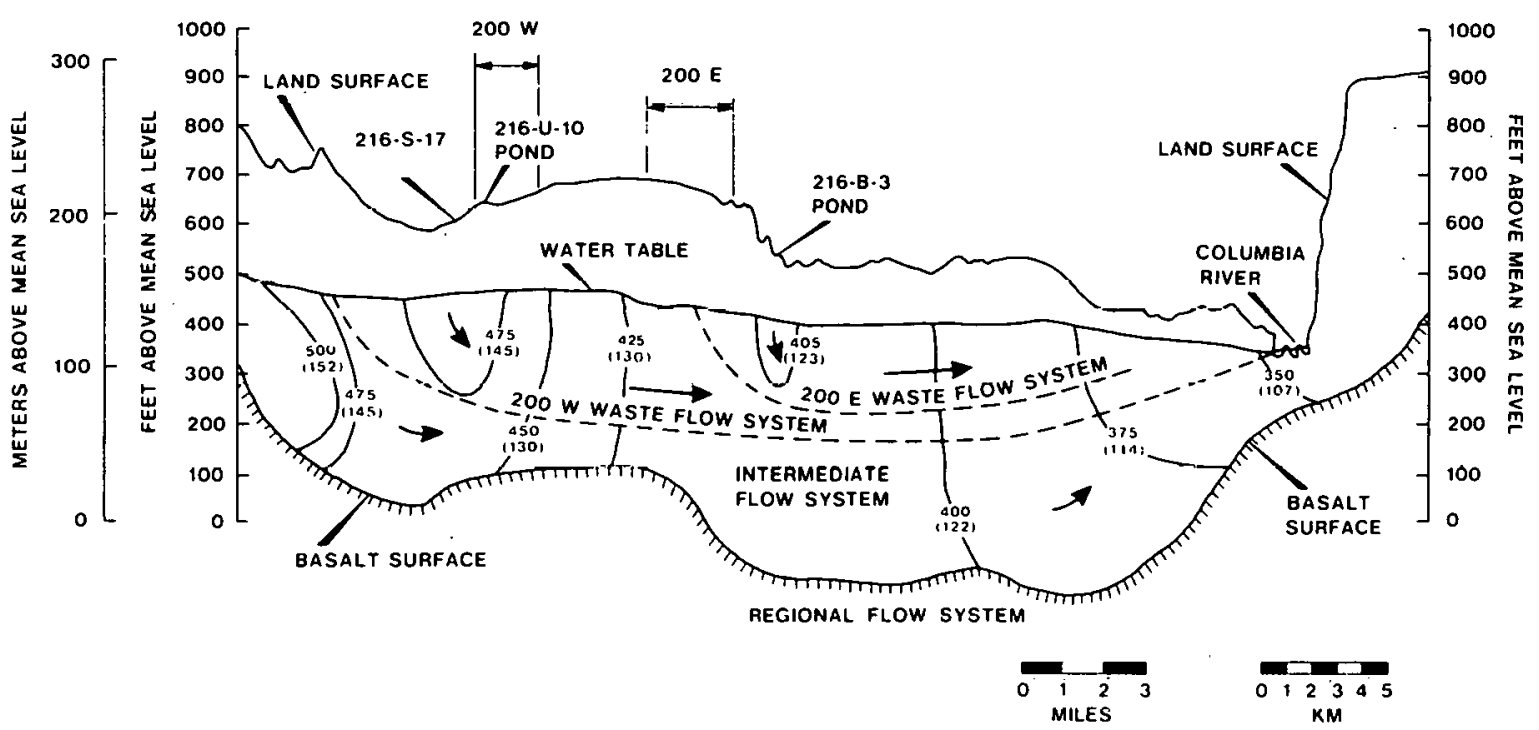

Y7คกว.19

\section{FIGURE 6.5}

HANFORD SITE FLOW SYSTEM 
The flow system of the 200 East Area and Gable Mountain Pond receives about two-thirds of the liquid waste disposed of at the Hanford Site. The input of these areas forms two "local" flow systems with in the "intermediate" flow'system of the 200 West Area. The Gable Mountain Pond flow system under-flows the small system that results from recharge on Gable Mountain.

\subsection{UNSATURATED ZONE}

The unsaturated (vadose) zone has been defined by the U.S. Geological Survey's Committee on Redefinition of Ground water Terms as:

". . the zone between the land surface and the water table. Characteristically, this zone contains liquid water under less than atmospheric pressure, and water vapor and air or other gases usually at atmospheric pressure. In parts of this zone, interstices may be temporarily or permanently filled with water. Perched water bodies may exist within the unsaturated zone."

On the Hanford Site, the thickness of the unsaturated zone varies from $<1$ meter to $>100$ meters.

The movement of water in the unsaturated zone is influenced by the physical properties of the sediments in two ways: (a) the size and structural arrangement of the sediment particles determine the space configuration through which the water moves; and (b) the interaction between the sediments and the water gives rise to water-moving forces. In sediments where pores are completely filled with water, the fluid is single phase. Where water does not completely fill the pores, the hydraulic potential depends on the gravitational field and on the absorptive forces associated with interfacial boundaries in the sediments. Where air partially fills the soil pores, with water occupying the remaining void space, a two-phase flow can take place. As the percentage of liquid water decreases, it occupies the smallest capillaries that exist between soil particles. 
During the period August 1, 1973 through July 31, 1974, Hanford experienced 170 percent of normal rainfall. At a field test site located south of the 200 East Area, where rainfall moisture penetration is measured routinely, this excessive rainfall penetrated less that 2.4 meters into the sediments. All moisture from rainfall during this period appears to have evaporated to the atmosphere. The data indicate that the loss of moisture by evaporation is greater than that gained through precipitation.

The Hanford sediments below a depth of about 9 meters are extremely dry. In this desiciated zorle, the movement of water is significantly impeded.

\section{$\underline{6.5}$ SURFACE HYDROLOGY}

\subsubsection{Topography and Drainage}

As Figure 6.6 shows, the Hanford Site lies along the Columbia River just north of (upstream from) the confluence with the Yakima River. Drainage in the northeastern two-thirds of the site is to the Columbia River directly; while drainage of the southwestern third is actually into the Yakima River. drainage basin, a subdivision of the Columbia River drainage basin.

Examination of the geologic map of Washington reveals that the Columbia River drainage basin occupies two distinctly different geologic terranes (see Chapter 7.0). The western terrane encompasses the Cascade Mountains where relatively old sedimentary, volcanic, and intrusive rocks have been uplifted and dislocated by erosion into the rugged mountains. The eastern terrane derives from a thick sequence of basalt flows (the Columbia River Basalt Group) folded into numerous southeast- to easttrending anticlinal ridges and synclinal valleys. Clastic sedimentary rocks partly f 111 the synclinal valleys to depths exceeding 450 meters in some of the larger valleys. The Hanford Site lies almost entirely within the Pasco Basin, one of the larger synclinal valleys in the eastern terrane. 


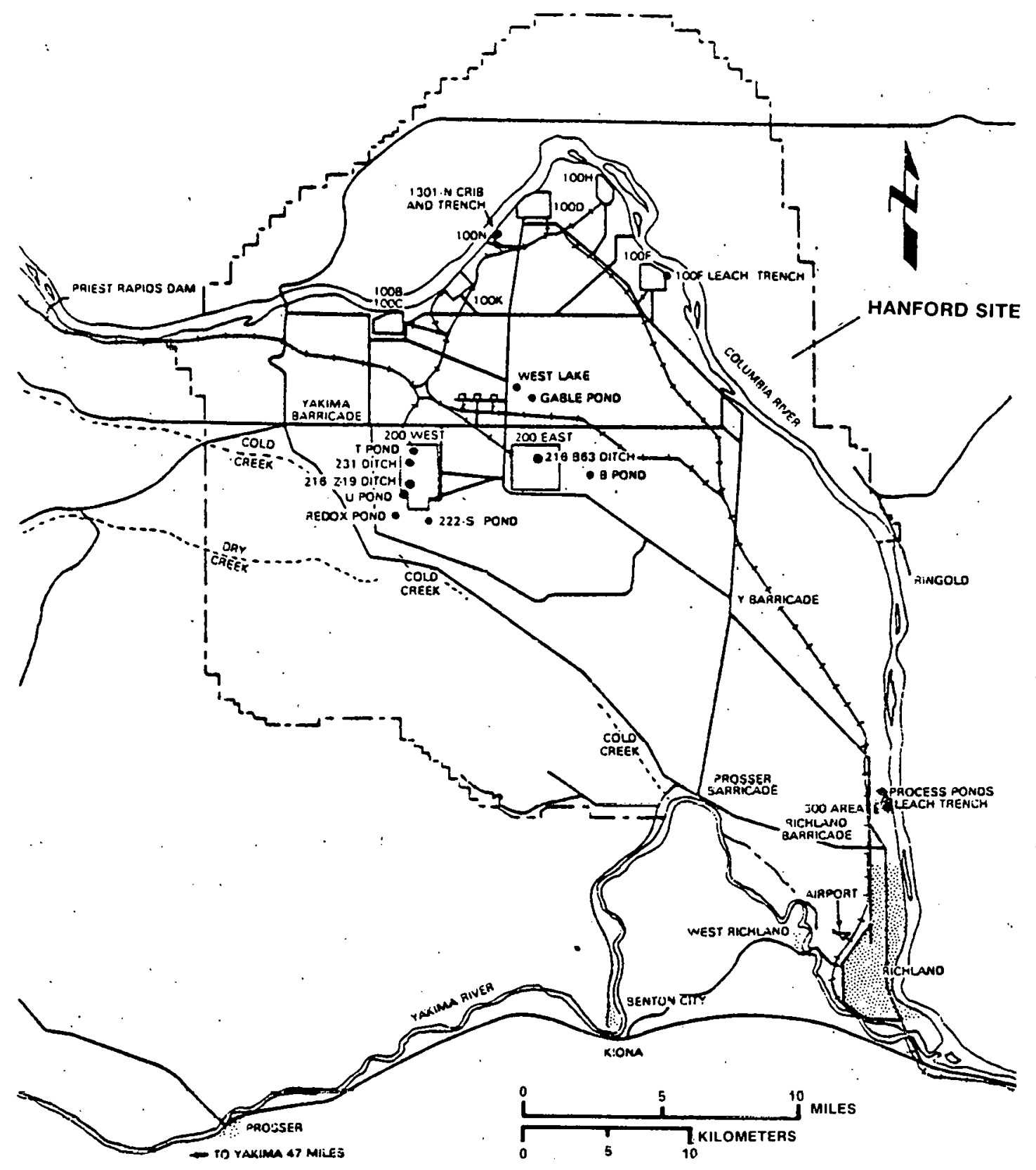

FIGURE 6.6

SURFACE WATER AREAS ON THE HANFORD SITE 
Direct precipitation over the Hanford Site mostly evaporates leaving a minimal amount of water and land runoff and for infiltration. The Yakima and the Columbia rivers are the only two permanent streams in the area. Cold Creek and Dry Creek carry water only during the spring season (Figure 6.7).

\subsubsection{Columbia River}

The river reach from Priest Rapids Dam (river mile 397) to the head (approximately river mile 351) of the reservoir behind McNary Dam is the last free-flowing reach of the Columbia River within the United States. The main channel is braided around the island reaches, and submerged rock ledges and gravel bars cause repeated pooling and channeling. The riverbed material is mobile, dependent on river velocities; it is typically sand, gravel, and rocks up to 20 centimeters in diameter. Small fractions of silts and clays are associated with the sands in areas of low-velocity deposition, becoming more dominant approaching the upstream face of each river dam. $(12,13,14)$

The Columbia River in this reach has widely varying flow rates due to regulation by the power-producing Priest Rapids Dam just upstream. Flows during the summer, fall, and winter vary from a low of 1,000 cubic meters per second to as much as 4,500 cubic meters per second each day. The long-term annual average flow at Hanford is about 3,400 cubic meters per second, ${ }^{(15)}$ but, during low flow periods, daily flows average 2,265 to 2,550 cubic meters per second. In recent years, peak flows during the spring runoff have ranged from 4,500 to 18,400 cubic meters per second; the maximum flood peak of record is 19,600 cubic meters per second in 1948.

The river width in the Hanford reach varies between 366 and 550 meters depending upon flow rate and position along the river. (16) The depth at the deepest part of the measured cross sections varies approximately from 3 to 12 meters, with an average around 7.6 meters. Daily fluctuations in depth caused by Priest Rapids Dam regulation can be as much as 3 meters above Vernita and 1.5 meters at Hanford. The maximum velocities measured vary from less than 1 meter per second to over 3.3 meters per second, again depending upon the river cross section and flow rate. 


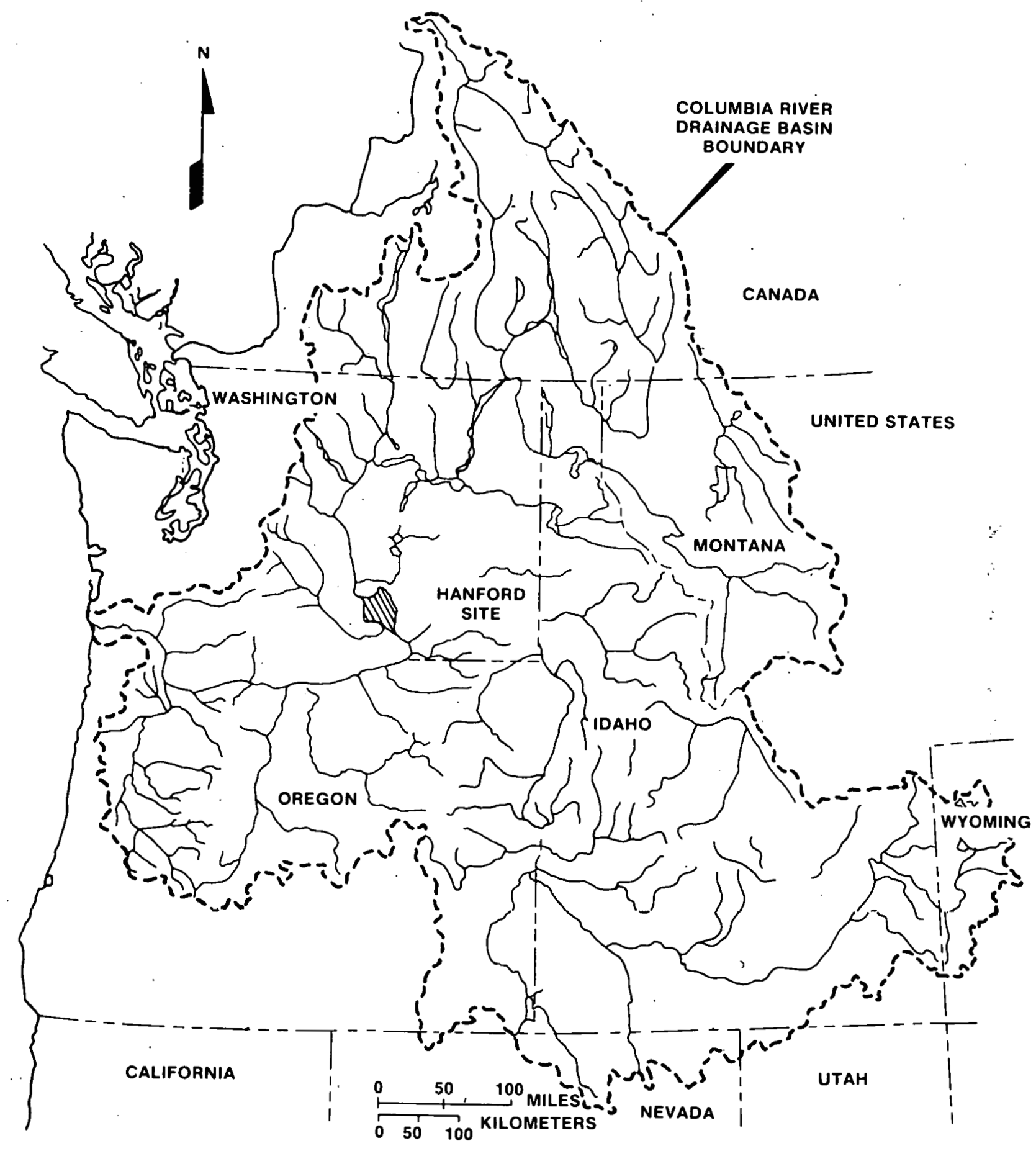

v7902-4.1

FIGURE 6.7 
Temperature measurements of the Columbia River have been continuously recorded both above and below the Hanford Site for many years. The maximum river temperature of record at Priest Rapids Dam was $20.7^{\circ} \mathrm{C}$ in August 1958. The annual mean temperature for $1960-1969$ was $10.8^{\circ} \mathrm{C}$.

Samples of river water for limited chemical analysis are taken routinely at Vernita, the 300 Area, and at Richland. Table 6.4 gives annual summaries of more complete data for 1972 at the Priest Rapids Dam location. (17)

\subsubsection{Yakima River}

The Yakima River is a small river with annual flow rates between 37 and 5,666 cubic meters per second. This river passes near the borders of the Hanford Site on the southern side. It is of little importance to the operations at Hanford, since no direct water withdrawal or disposal are made. However, its entrance into the Columbia River at Richland diverts the main river away from the southern shore from the mouth of the Yakima River to Kennewick. Beyond Horn Rapids, the Yakima River loses water continually through its bed and banks until it joins the Columbia River.

Continuous flow data in the vicinity of Hanford are available from a water stage recorder located at Kiona (approximately 32 kilometers west of Richland). The mean flow for 1972 was 190 cubic meters per sécond. (15)

\subsubsection{Surface Water on the Hanford Site}

The Hanford Site contains a number of man-made ditches and ponds which are used for the disposal of low-level radioactive liquid waste, certain industrial waste, and cooling waters from various processes. They include several large ponds, $U$ Pond in the 200 West Area, B Pond lying east of the 200 East Area, and Gable Mountain Pond and West Lake north of the 200 East Area (Figure 6.3). Several others, such as Redox Pond, are no longer in use and have been filled and covered. $A-29$ and B-3 ditches carry water to $B$ Pond, and Z-19 Ditch discharges into $U$ Pond. 100-N Trench lies immediately northeast of the $\mathrm{N}$-Reactor site near the Columbia River. The 300 Area trenches receive manufacturing process and cooling water from fuel fabrication processes and small amounts of laboratory waste, including waste from the 331 Building 


\section{TABLE 6.4}

AVERAGE CHEMICAL CONCENTRATIONS IN THE COLUMBIA RIVER AT PRIEST RAPIDS DAM

OCTOBER 1971 TO SEPTEMBER 1972

$\frac{\text { CHEMICAL }}{\text { Calcium }}$
Magnesium
Sodium
Potassium
Chromium
Copper
Lead
Total Mercury
Zinc
Bicarbonate
Sulfate
Chloride
Kjeldahl Nitrogen

CONCENTRA-ION

$19.0 \quad(\mathrm{mg} / \mathrm{l})$

$4.3 \quad(\mathrm{mg} / \mathrm{l})$

$2.1 \quad(\mathrm{mg} / \mathrm{l})$

$1.4(\mathrm{mg} / \mathrm{l})$

0 *

$2.6 * \quad(\mu \mathrm{g} / \ell)$

8.0* $(\mu \mathrm{g} / \mathrm{l})$

$0.9 * \quad(\mu \mathrm{g} / \ell)$

32.0*. $(\mu \mathrm{g} / \ell)$

$72.0 \quad(\mathrm{mg} / \mathrm{l})$

$13.0 \quad(\mathrm{mg} / \mathrm{l})$

$1.5(\mathrm{mg} / \mathrm{l})$

$.29(\mathrm{mg} / \mathrm{l})$

\section{CHEMICAL}

Ammonia Nitrogen

Nitrite

Nitrate

Ortho-Phosphorus

Total Phosphorus

Total Alkalinity

Hardness

Non-Carbonate Hardness

Specific Conductance

$\mathrm{pH}$

Dissolved Solids

Color

\begin{tabular}{cl}
\multicolumn{2}{c}{ CONCENTRATION } \\
\hline 0.07 & $(\mathrm{mg} / \mathrm{l})$ \\
0.006 & $(\mathrm{mg} / \mathrm{l})$ \\
0.26 & $(\mathrm{mg} / \mathrm{l})$ \\
0.013 & $(\mathrm{mg} / \ell)$ \\
0.037 & $(\mathrm{mg} / \ell)$ \\
59.0 & $(\mathrm{mg} / \mathrm{l})$ \\
66.0 & (mg/l) \\
06.8 & (mg/l) \\
158.0 & (micro-ohms) \\
7.8 & (units) \\
107.0 & (mg/l) \\
15.0 & (Platinum- \\
& Cobalt \\
& Units)
\end{tabular}


laboratories and effluent liquor from the animal pen septic tanks. Sanitary waste from laboratory, office, and manufacturing facilities is routed to a septic tank, with overflow to leach trenches. No intermediate- or high-level radioactive waste is routed to any of the ponds.

With the exception of West Lake, all of these aquatic systems were created on the Hanford Site since the beginning of the Manhattan Project in 1943. The water supply for these systems, except West Lake and 100-N Trench, is withdrawn from the Columbia River near the B- and D-Reactor sites. This supply serves the processing and waste-handling facilities in the 200 Areas and is used mainly as cooling water. After passing through these facilities, it is discharged into pipes and ditches leading to the ponds. River water is withdrawn directly at the $\mathrm{N}$-Reactor site to supply its operations; some of this water is discharged into 100-N Trench. West Lake is a window in the ground water table and is fed from underground sources. Originally ephemeral, it became permanent after large quantities of river water were used for processing and cooling in the 200 Areas.

Tables 6.5 and 6.6 show measured physical and chemical characteristics of ponds and surface streams on the Hanford Site.(18)

\subsection{5_Flonds}

A calculation of the effect of a Columbia River flood that might occur in the next 1,000 years on waste management operations has been performed and reported.(9) The flooding condition used in the analysis is the dam-regulated "Probable Maximum Flood" (PMF) previously predicted by the U.S. Army Corps of Engineers. (9) This prediction was derived using extensive data and computer modeling techniques and incorporating assumptions of a combination of conditions which were the most severe considered "reasonably possible" for the Columbia River basin. Contributing factors of winter snow accumulation, spring melting, and runoff-season rainstorms were maximized.

The basic cause of the PMF would be spring snowmelt runoff in the mountains of the Columbia River watershed following exceptionally cold and wet weather during the October to April snow accumulation season. It was assumed that, over the Columbia River basin as a whole, the October 


\section{TABLE 6.5}

PHYSICAL AND CHEMICAL CHARACTERISTICS OF PONDS ON THE HANFORD SITE

(Means are shown with 95 percent confidence values; i.e., mean \pm confidence value $=$ 95 percent confidence interval about the mean.)

\begin{tabular}{|c|c|c|c|c|c|c|c|}
\hline & \multicolumn{2}{|c|}{ GABI_E POND } & B POND & \multicolumn{2}{|r|}{ U POND } & \multicolumn{2}{|c|}{ West Pond } \\
\hline Surface Area $\left(\mathrm{m}^{2}\right)$ & & 7,300 & 149,200 & & 55,700 & 77 & 7,800 \\
\hline (acres) & & 1.0 & 36.9 & & 14.0 & & 9.2 \\
\hline Volume $\left(\mathrm{m}^{3}\right)$ & & 1,000 & 233,200 & 2 & 22,700 & & 1,100 \\
\hline$(\operatorname{acre}-f t)$ & $35 i$ & & 190 & & 18.4 & & 5.1 \\
\hline Mean Depth $(m)$ & & 1.5 & 1.6 & & 0.4 & & 0.4 \\
\hline$(f t)$ & & 7.9 & 5.2 & & 1.3 & & \\
\hline 1.3 & & & & & & & \\
\hline Retentian Time (hrs) & 504 & \pm 211 & $424 \pm 183$ & & $7 \pm 4$ & & $-\star$ \\
\hline Temperature Range $\left({ }^{\circ} \mathrm{C}\right)$ & & -25.3 & $0-25.0$ & & $0-28.4$ & & -25.5 \\
\hline Insolation Range (Langleys & 20 & -253 & $20-253$ & & $0-253$ & & -253 \\
\hline Seston $(\mathrm{mg} / \ell)$ & 14.5 & \pm 10.9 & $12.2 \pm 17.4$ & 24.0 & \pm 8.9 & 21.6 & \pm 9.6 \\
\hline $\begin{array}{l}\text { Sedimentiation Rate } \\
\left(\mathrm{mg} / \mathrm{cm}^{2} \text { per day }\right)\end{array}$ & 2.43 & \pm 0.76 & $0.81 \pm 0.51$ & 2.24 & $4 \pm 1.42$ & 11.20 & \pm 6.50 \\
\hline pH Range & 7.8 & -8.7 & $7.0-9.0$ & 7.0 & -9.5 & 9.7 & -10.0 \\
\hline Alkalin:ty $\left(\mathrm{mg} / \mathrm{l}\right.$ as $\mathrm{CaCO}_{3}$ & 58.4 & \pm 6.1 & $57.1 \pm 4.8$ & 5.2 & \pm 6.5 & 9,009 & \pm 1924 \\
\hline Diss. 0, Range $(\mathrm{mg} / \mathrm{l})$ & 7.9 & -12.7 & $8.1-13.8$ & 9.0 & -13.00 & 8.0 & -13.8 \\
\hline Hardness (mg/l as $\mathrm{CaCO}_{3}$ ) & 67.4 & \pm 6.0 & $68.0 \pm 4.2$ & 72.4 & \pm 14.1 & 121.8 & \pm 7.6 \\
\hline $\begin{array}{l}\text { Conduct vity } \\
\left(\mu \mathrm{mhos} / \mathrm{cm} \quad 25^{\circ} \mathrm{C}\right)\end{array}$ & 1,327 & \pm 104 & $1,251 \pm 170$ & 1,553 & \pm 132 & 229,698 & $3 \pm 42,292$ \\
\hline
\end{tabular}


Table 6.5 (continued!

\begin{tabular}{|c|c|c|c|c|}
\hline & GABLE POND & B POND & $\cup$ POND & West Pond \\
\hline Total $\mathrm{NO}_{3}-\mathrm{NO}_{2}-\mathrm{N}(\mathrm{mg} / \mathrm{s})$ & $0.18 \pm 0.07$ & $3.65 \pm 1.33$ & $0.28 \pm 0.08$ & - \\
\hline Total $\mathrm{NH}_{3}-\mathrm{N}(\mathrm{mg} / \mathrm{l})$ & $0.38 \pm 0.10$ & $1.04 \pm 0.51$ & $0.45 \pm 0.20$ & $2.61 \pm 0.40$ \\
\hline Ortho $\mathrm{PO}_{4}-\mathrm{P}(\mu \mathrm{g} / \mathrm{l})$ & $1.0 \pm 0.1$ & $4.5 \pm 4.2$ & $57.8 \pm 25.1$ & $2050 \pm 180$ \\
\hline Total $\mathrm{PO}_{4}^{4}-\mathrm{P}(\mu \mathrm{g} / \ell)$ & $38.0 \pm 10.0$ & $40.4 \pm 10.0$ & $123.0 \pm 56.0$ & $2160 \pm 140$ \\
\hline Total $\mathrm{SiO}_{2}-\mathrm{Si}(\mathrm{mg} / \mathrm{l})$ & $0.99 \pm 0.22$ & $1.53 \pm 0.41$ & $0.80 \pm 0.43$ & $0.23 \pm 0.21$ \\
\hline
\end{tabular}

*No data available. 
TABLE 6.6

PHYSICAL AND CHEMICAL CHARACTERISTICS

FOR STREAMS (DITCHES AND TRENCHES) ON THE HANFORD SITE

(Means are shown with 95 percent confidence values; i.e., mean + confidence value = 95 percent confidence interval about the mean.)

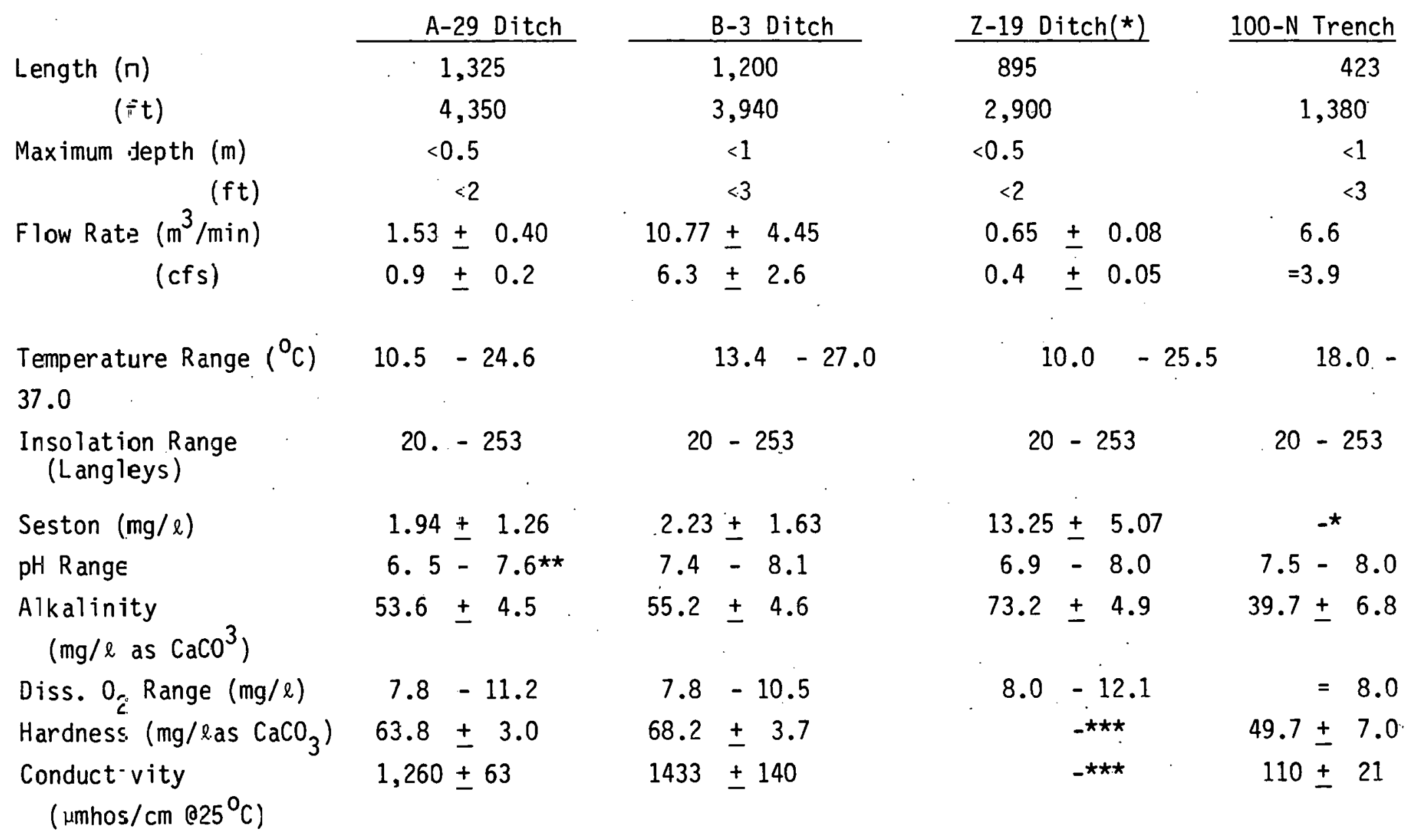


Table 6.6 (continued)

\begin{tabular}{|c|c|c|c|c|}
\hline & A-29 Ditch & B-3 Ditch & Z-19 $\operatorname{Bitch}^{(*)}$ & 100-N Trench \\
\hline Total $\mathrm{NO}_{3}-\mathrm{NO}_{2}-\mathrm{N}(\mathrm{mg} / \mathrm{l})$ & $0.19 \pm 0.15$ & $3.74 \pm 1.28$ & $0.30=0.36$ & $-\star \star \star \star$ \\
\hline Total $\mathrm{NH}_{3}-\mathrm{N}(\mathrm{mg} ; \ell)$ & $0.67 \pm 0.84$ & $1.61 \pm 1.10$ & $0.09=0.04$ & $-\star \star \star$ \\
\hline Ortho $\left(\mathrm{PH}_{4}-\mathrm{P}(\mu \mathrm{g} / \mathrm{l})\right.$ & $11.9 \pm 10.2$ & $9.8 \pm 7.6$ & $90.0-49.7$ & $-\star \star \star \star$. \\
\hline Total $\mathrm{PO}_{4}-\mathrm{P}$ (ugi 2$)$ & $45.1 \pm 9.0$ & $48.2 \pm 10.8$ & $105.0-54.0$ & $-\star \star \star$ \\
\hline Total $\mathrm{SiO}_{2}^{4}-\mathrm{si}(\mathrm{mg} / \mathrm{s})$ & $2.08 \pm 0.42$ & $2.01 \pm 0.42$ & $4.73 \div 8.35$ & $-\star \star \star$ \\
\hline
\end{tabular}

*Díscharges into Z-19 $\mathrm{d}^{\star}$ tch were substantially reduced in March 1976.

$\star \star R$ ange may be broader on an intermittent basis.

$\star \star \star$ No data available. 
to April precipitation equaled 1.3 times the normal annual precipitation. Unusually rapid melting due to meteorological conditions was predicted as a result of the assumption of extreme seasonal values for air temperatures, dew point, solar radiation albedo, and wind speed.

In addition, two hydrologically significant (the most severe considered "reasonably possible") basin-wide rainstorms were assumed. It was also assumed that rain contributions to the PMF fell entirely during two five-day periods during the snowmelt season: the first was. arbitrarily chosen in mid-May; the second was timed to maximize the natural peak discharge of the lower Columbia River. This calculation shows that, even under these circumstances, the flood would be restricted to a narrow zone adjacent to the Columbia River.

The probable maximum 24-hour precipitation that can be expected in the Hanford region at least once in 1 million years is about 28 centimeters. (19) The maximum recorded 24-hour precipitation has been 4.85 centimeters. Even a 28-centimeter, 24-hour downpour flooding would be confined to the immediate areas along the Columbia River.

Estimates of the consequences of hypothetical (artificial) floods have been reported. (20) A worst-case event would result from a postulated 50 percent breach of Grand Coulee Dam. The ensuing flood of $2.24 \times 10^{5}$ cubic meters per second would crest at about 140 meters above mean sea level in the channel between 200 East Area and Gable Mountain. 


\subsection{REGIONAL GEOLOGY}

The regional geology is dominated by Cenozoic volcanic rocks and structures. A generalized geologic map of the region is shown in Figure 7.1. A regional tectonic map is shown in Figure 7.2. The major regional geologic provinces are described in the following subsections.

\subsubsection{Columbia Basin}

The Columbia Basin is a broad structural basin that was dnwnwarped while lavas were periodically being extruded. The region continued to deform, forming anticlinal ridges coincident with the axes of the anticlines. The Columbia Basin contains a thick sequence of Miocene-Pleistocene lacustrine and fluvial sediments, Pleistocene glaciofluvial sediments, and Holocene alluvium, colluvium, and eolian deposits.

\subsubsection{Blue Mountains}

The Blue Mountains Section is a northeasterly trending complex of deformed eugeosynclinal Paleozoic and Mesozoic sediments and intrusive Cenozoic rocks that lies south of the Columbia Basin Section. The structure is generally described as an asymmetric anticline with a steep northern flank and gently dipping southern flank. Some of the region is covered with basalt which has been elevated and deformed by continued orogenic activity. Resulting erosion has stripped much of the younger basalts and exposed Paleozoic and Mesozoic rocks not found in the Columbia Basin. The present topography is a result of major Pliocene deformation and Quaternary erosion.

\subsubsection{Harney Region}

This province lies south of the Blue Mountains and extends from the Cascades to the Steens Mountains in southern Oregon. This region is similar to the Columbia Basin in that it is dominated by basalt flows and sedimentary interbeds. The region lacks the fluvial and eolian overburden found in the Columbia Basin. 


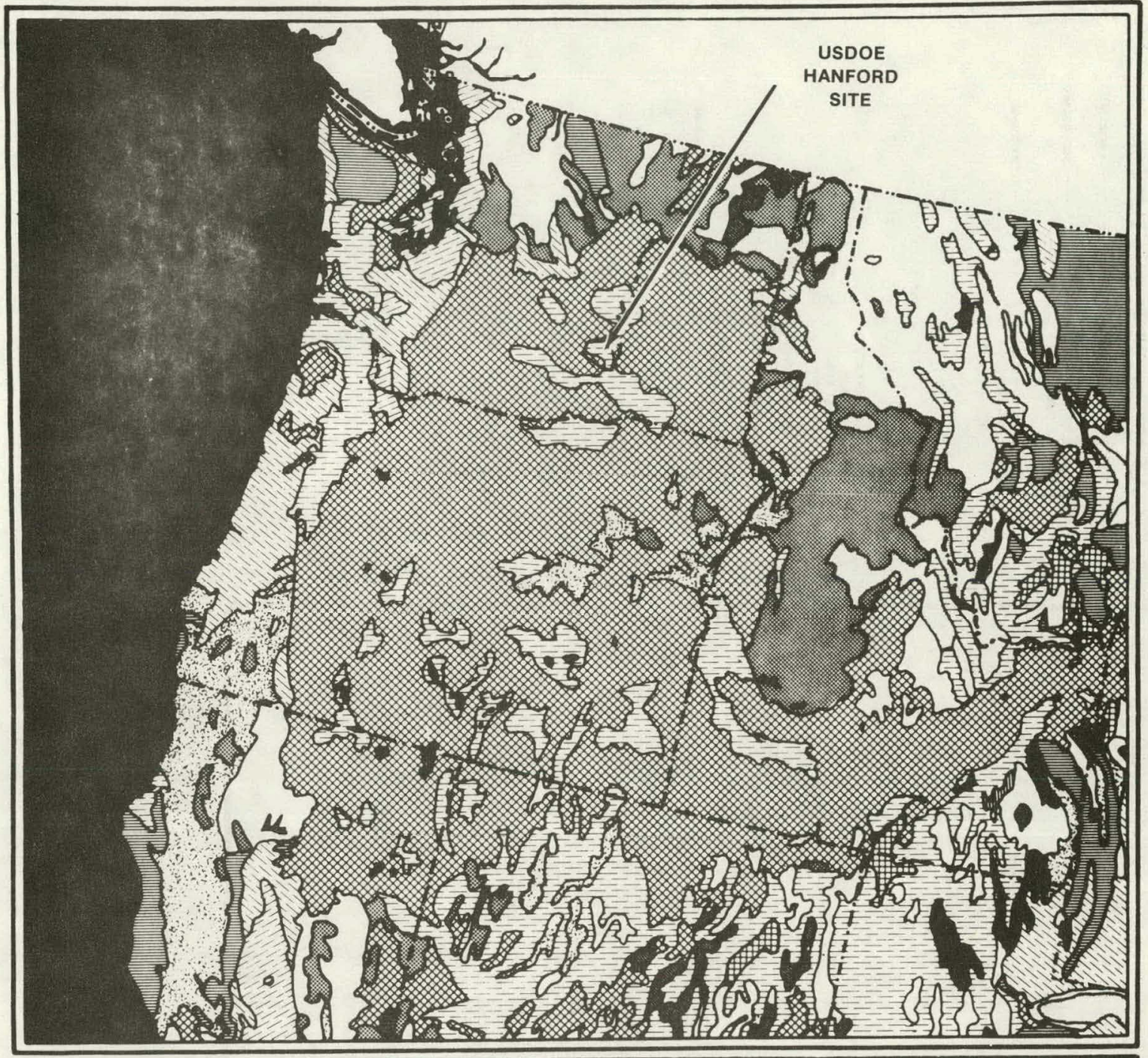

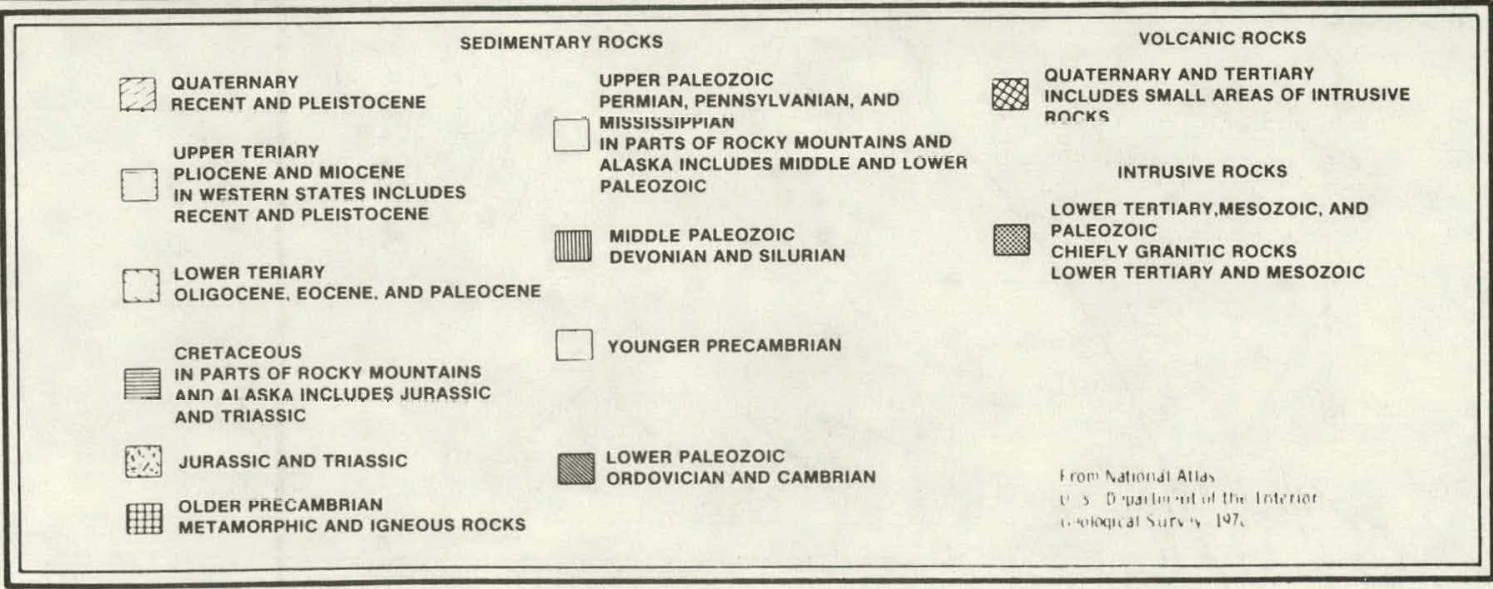

FIGURE 7.1 

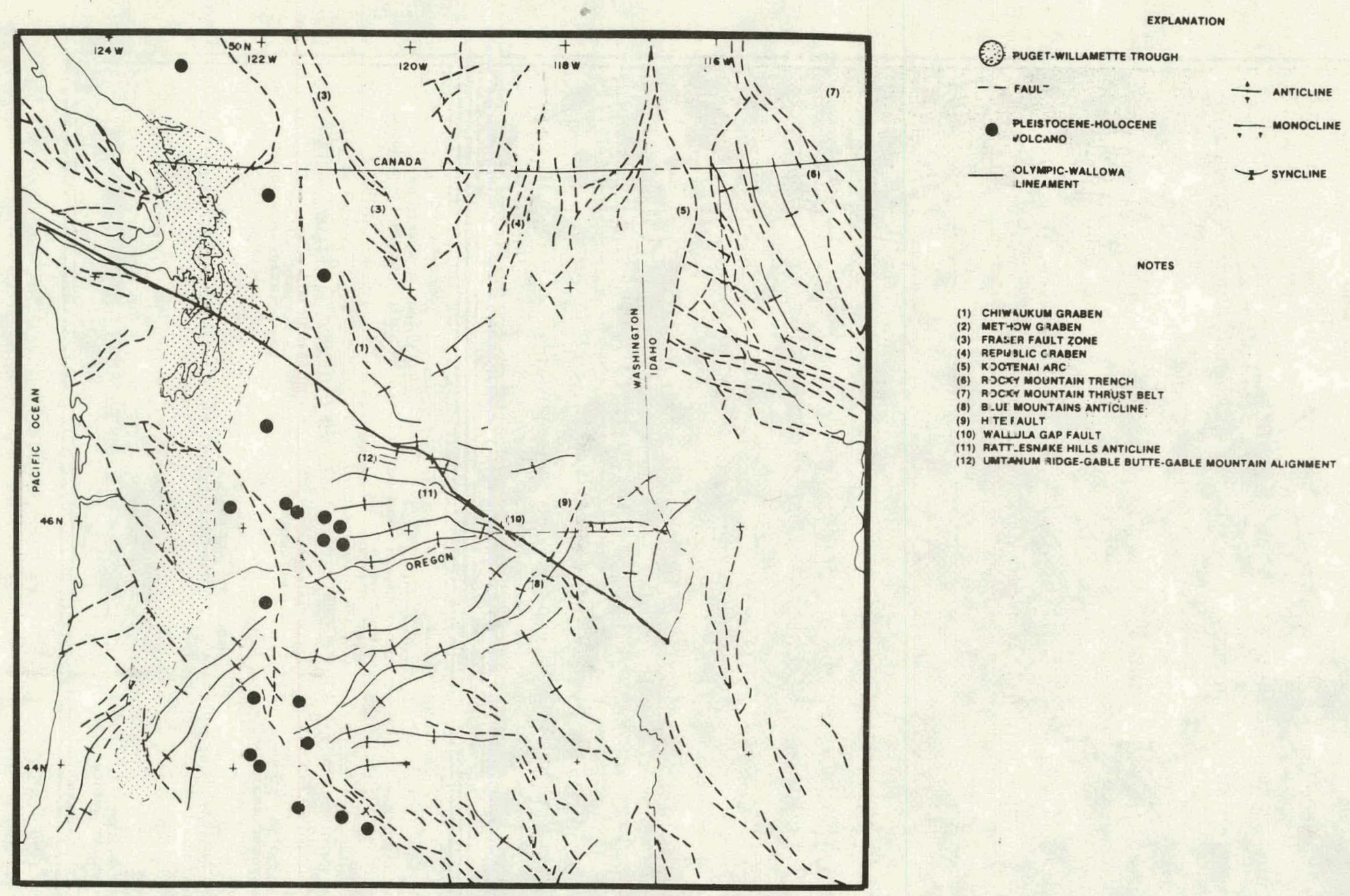

\section{=IGURE 7.2}

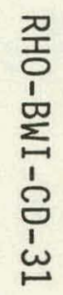

REGIONAL TECTONIC MAP

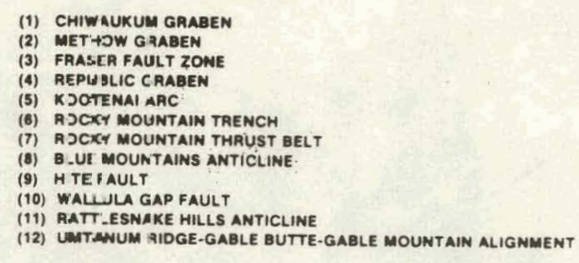




\subsubsection{Idaho Batholith}

The Idaho Batholith lies southeast of the Columbia Basin and south of the Idaho-Montana Northern Rocky Mountains Section. The most prominent rock types are quartz monzonites and granodiorites with some granites. The main batholithic intrusion took place during the Cretaceous period.

\subsubsection{Idaho-Montana Northern Rocky Mountains Section}

This section is northeast of the Columbia Basin and primarily consists of an extensive segment of Precambrian crystalline and sedimentary rocks. The dominant rock types are quartzites, slates, and argillites of the Belt Supergroup.

\subsubsection{Okanogan Highlands}

This province, which lies north of the Columbia Basin, can be divided into two geologic regions. (1) East of the Columbia River the region is composed of Precambrian Beltean rocks and lower Paleozoic miogeosyriclinal rocks primarily composed of quartzite, phyllites, and carbonates. This portion of the highlands has been folded and faulted during several periods of deformation and was intruded by granitic batholiths. The folds of this belt are cut by pre-Tertiary faults.

The area west of the Columbia River is composed of eugeosynclinal graywackes, greenstones, slates, cherts, conglomerates, and limestones. The sediments have been intruded by late Mesozoic quartz monzonites and granodiorites. Tertiary volcanics unconformably cap the older rocks. The western portion contains north-south-trending high-angle normal faults which have preserved the Tertiary rocks by down-faulting into older crystalline rocks.

\subsubsection{Cascade Range}

This north-south-trending morphologic geotectonic province extends. from southern British Columbia to northern California and the western boundary of the Columbia Basin. Broad up-arching in this province occurrêd normal to a north-suuth ax is during late Pliocene and early Pleistocene time. Uplift increased to the north, reached a maximum in the North Cascades near the Canadian border, and decreased to the south. Quaternary volcanic activity built large strato-volcanic cones which 
dominate the southern portion of the range and decrease in number to the north.

The Cascade Range can be divided into three geologic

sub-provinces. (1) They are the Western Cascades of Oregon, the High Cascades of Oregon and Washington, and the North Cascades of Washington. The High Cascades are composed of coalescing Pliocene shield volcanoes capped with Quaternary strato-volcanoes. The Western Cascades of Oregon extend the length of Oregon and into southern Washington and are composed of slightly to moderately deformed rocks of Eocene through Miocene age. The North Cascades include that part of the range north of Snoqualmie Pass and are dominated by pre-Cenozoic igneous and metamorphic rocks.

The geology of the North Cascades is strongly influenced by large steeply dipping faults of late Mesozoic to early Cenozoic age. The crystalline core is composed of deformed schists and gneisses and is flanked by younger sedimentary and volcanic rocks. In general, the oldest rocks are the most strongly deformed.

\subsubsection{Puget-Willamette Trough}

This province lies between the Cascade Range and the Coast Range. The structure is a broad downwarp with transverse-trending faults and folds. Rock outcrops are closely related to the Tertiary rocks of the nearby Cascade Range and Coast Range provinces. The lowland contains thick deposits of Quaternary fill.

\subsubsection{Coast Range}

The Coast Range of Washington and Oregon extends more than 950 kilometers from the $\mathrm{Kl}$ amath Mountains of southwestern Oregon to the Straits of Juan de Fuca in northwestern Washington. Tertinry eugeosynclinal sediments are exposed in the core of the 0lympic Mountains and the Coast Range, the oldest of which are low-grade metasediments, argillites, and graywackes. The flanks of the 0lympic Mountains are made up of marine basalts and marine sedimentary rocks of Eocene and Miocene age. The anticlinorium in the Coast Range south of the Olympic Mountains is Miocene and Pliocene in age. 


\subsection{GEOLOGIC SETTING OF THE HANFORD SITE}

One of the largest accumulations of continental basaltic rock (Figure 7.3) is in the northwestern part of the United States ${ }^{(2)}$ in the physiographic province known as the Columbia River Plateau (Figure 5.1). Field studies indicate that enormous volumes of basaltic magma welled up through fissures in the earth's crust to form sheets over an area estimated at 150,000 square kilometers. The basalt magma probably had a low viscosity with very little gas trapped in the rock, as evidenced by the uniformity of flow thicknesses over large areas and the limited zones of vesicular basalt within a flow. Accompanying the eruption of basalts from fissures, nearby volcanoes blanketed the area with ash, and ancestral rivers deposited sediments on the ground surface, both of which were then covered by the next flow.

The average thickness of the basalt sequence over the Columbia River Plateau is approximately 550 meters. However, the greatest known thickness is beneath the Hanford Site where basalt accumulated to thicknesses greater than 3,000 meters in the Pasco Basin in the northwestern part of the plateau. The Pasco Basin is the structural and topographic low point of the Columbia River Plateau. The land surface near the center of the basin is about 150 meters above sea level and the underlying basalt surface is as much as 80 meters below sea level. The principal topographic features around the Pasco Basin are shown in Figure 5.2 .

The most prominent landforms in the region surrounding the Pasco Basin are the anticlinal ridges that began to rise more than 10 million years ago in late Miocene time. The Saddle Mountains, bordering the basin to the north, are about 90 kilometers long and trend east-west. The mountains are fairly uniform in height and range from 600 to 821 meters above sea level. The highest point on the crest is Wahatis Peak. Structurally, the Saddle Mountains are an asymmetric anticline with a steep northern slope and a gentle southern slope. The axial trace of the anticline and the ridge crest of the Saddle Mountains do not generally coincide because portions of the anticline have been eroded at the axis.

At the western end of the Saddle Mountains, the Columbia River enters the Pasco Basin through Sentinel Gap. Uplift of the Saddle Mountains was so gradual that the Columbia River maintained its original course by 


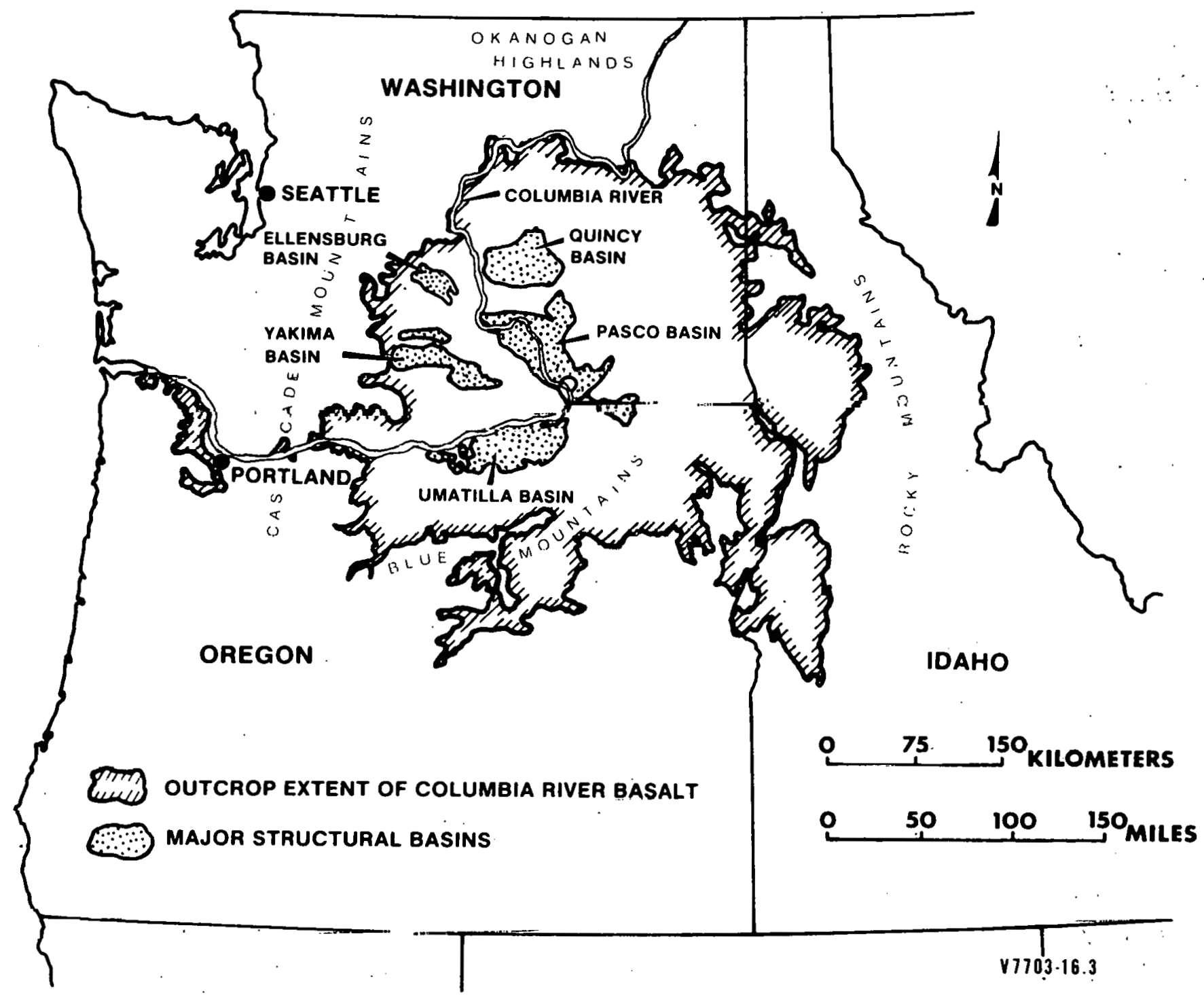

FIGURE 7.3

GEOGRAPHIC EXIENT OF COLUMBIA RIVER BASÁLT 
slowly abrading the basalt surface. To the east, the Saddle Mountains structure swings slightly southeast and subsequently plunges beneath fluvial sediments.

Two basalt ridges occur along the western portion of the Pasco Basin. The most northerly of the two is Umtanum Ridge, which rises more than 1,000 meters above sea level. The northern limb of this anticline is sharply folded and at a point near the Priest Rapids Dam, where the Columbia River impinges against this ridge, the flows are overturned (dipping 80 to 85 degrees to the south). Eastward, the main ridge plunges beneath the basin fill. It crops out again near the center of the basin at Gable Butte and Gable Mountain (Figure 5.2). Yakima Ridge lies immediately south of Umtanum Ridge. The crest of this ridge to the west of the Pasco Basin is 1,290 meters above mean sea level and is the highest point within the Pasco Basin region. The southeastern continuation of Yakima Ridge lies buried beneath the basin fill.

The Ratt lesnake Hills are south of Yakima Ridge. This anticlinal structure is the most prominent topographic feature bordering the Pasco Basin. The asymmetry of this ridge is typical of most ridges in the region. At the western margin of the Pasco Basin, the Rattlesnake Hills trend northwest-southeast. Along the Rattlesnake Hills, the highest elevation is approximately 1,036 meters. To the southeast, the Rattlesnake Hills structure is exposed above the fluvial plain as a series of doubly plunging anticlines and elongate domes. This continuation of the Rattlesnake Hills structure eventually merges with the Horse Heaven Hills to the southeast, near the junction of the Snake River and Walla Walla River with the Columbia River at the southern boundary of the Pasco Basin.

The Pasco Basin is bordered on the east by the Jackass Mountain monocline.

\subsection{GEOLOGY OF THE HANFORD SITE}

\subsubsection{Stratigraphy}

The stratigraphy surrounding the site is given in Figure 7.4. (3) Figures 7.5, 7.6, and 7.7 are geologic cross sections of the Pasco Basin. 


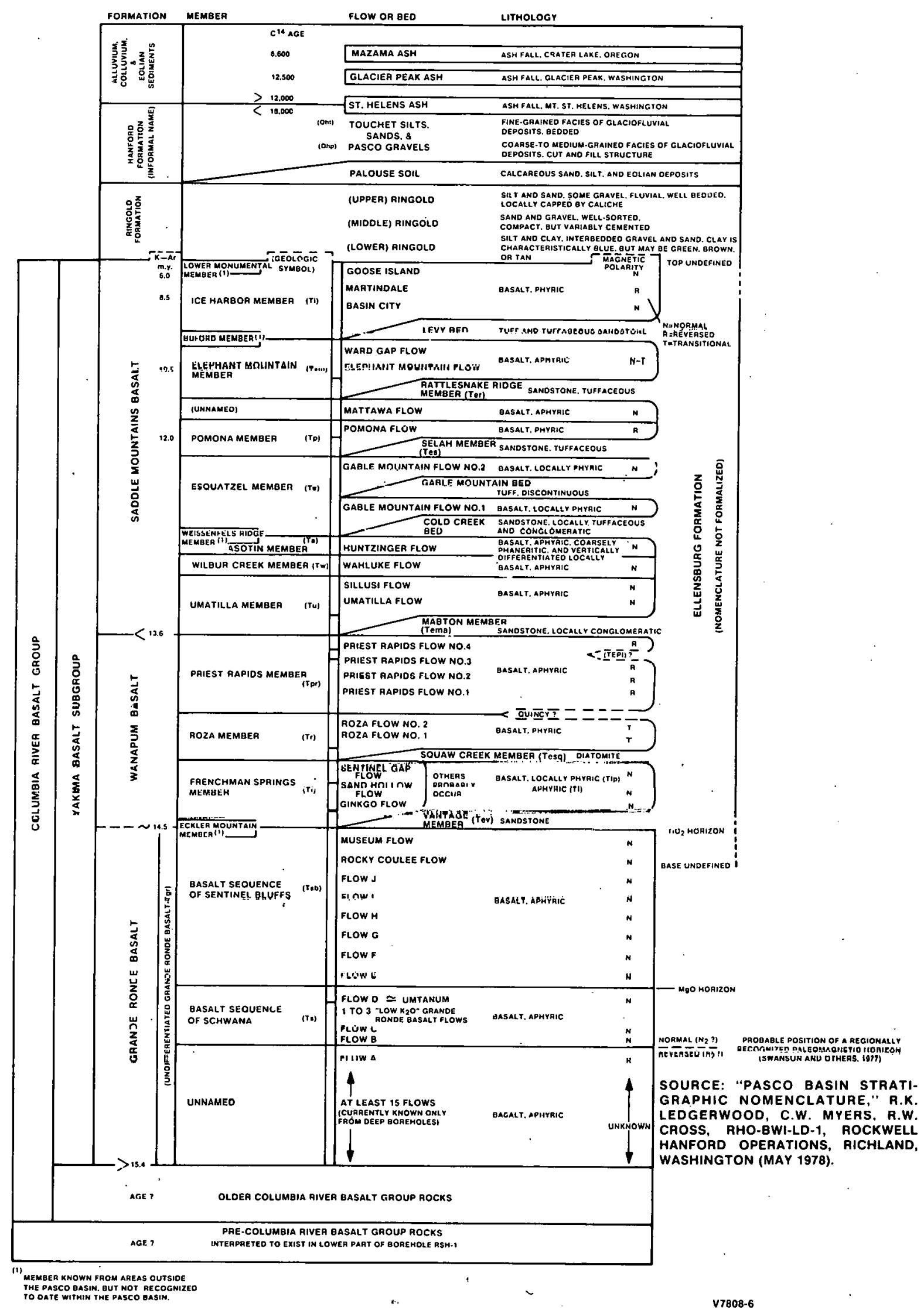

FIGURE 7.4 


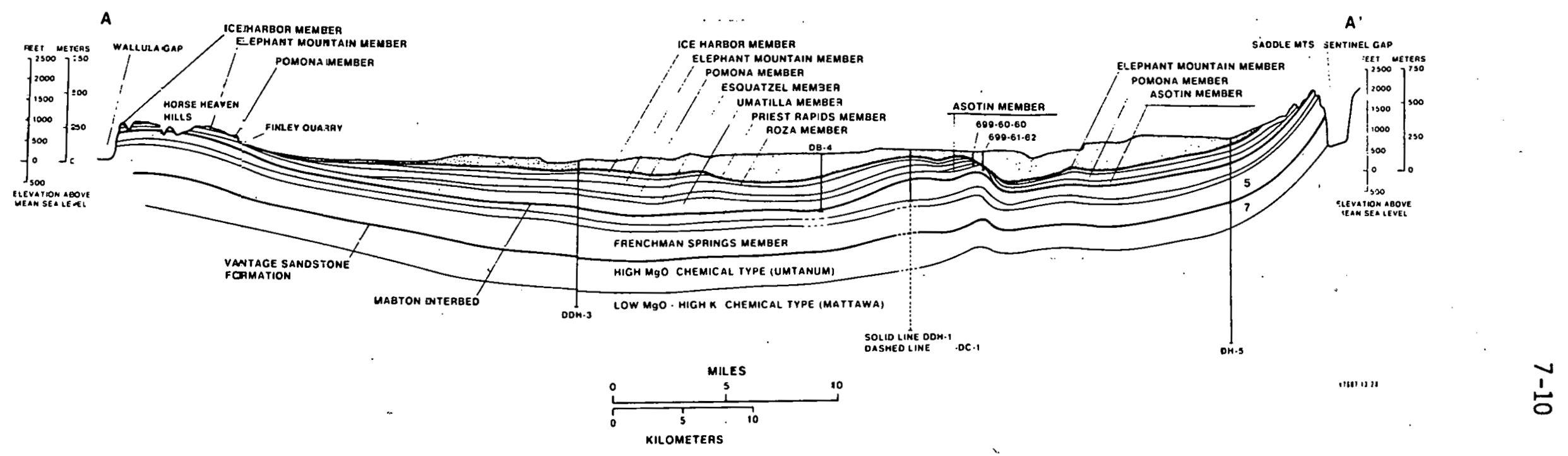

\section{FIGURE 7.5}

GENERALIZED CROSS SECTION, A-A' PARALLEL TO MAIN AXIS OF THE PASCO BASIN 


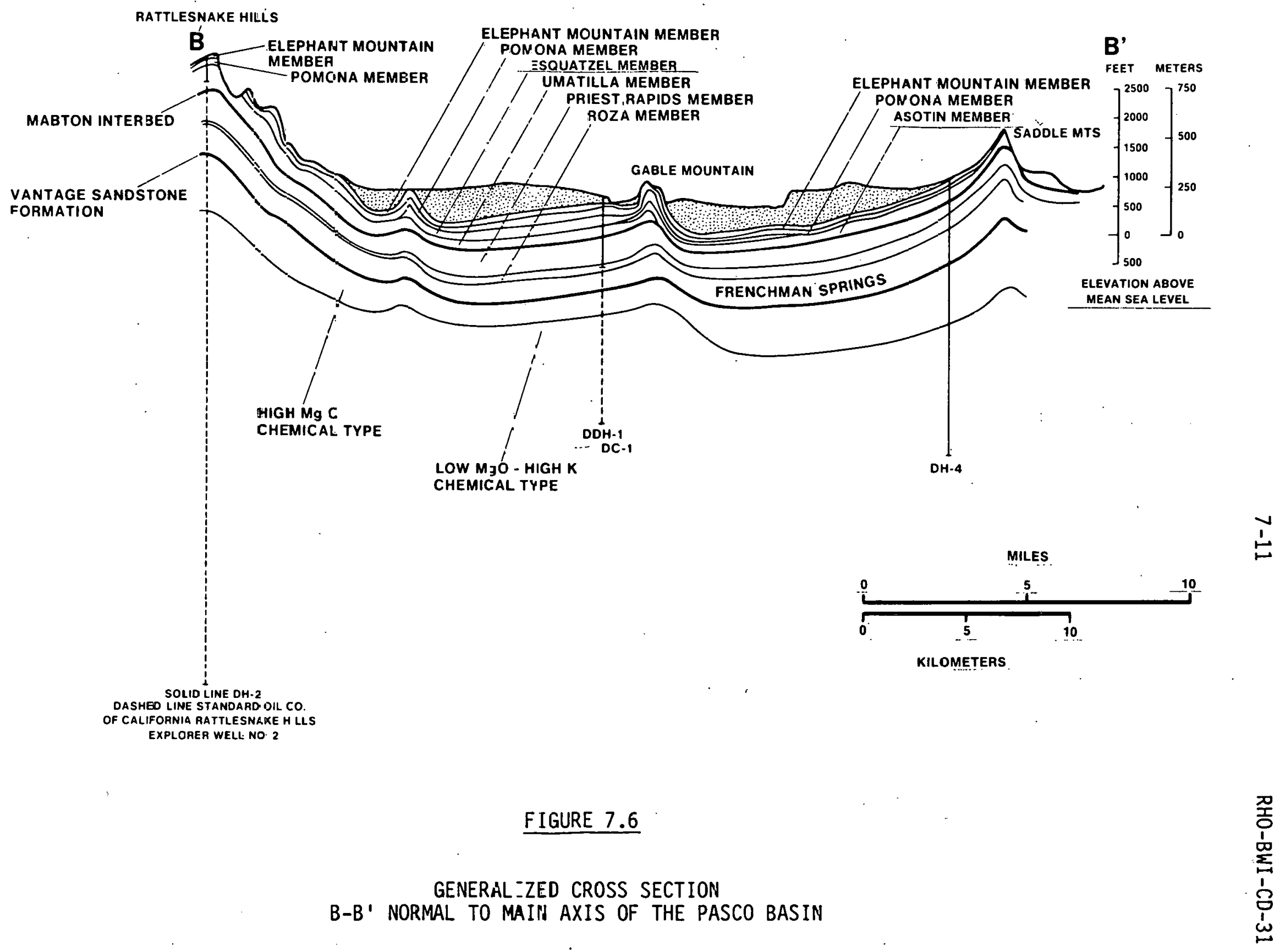




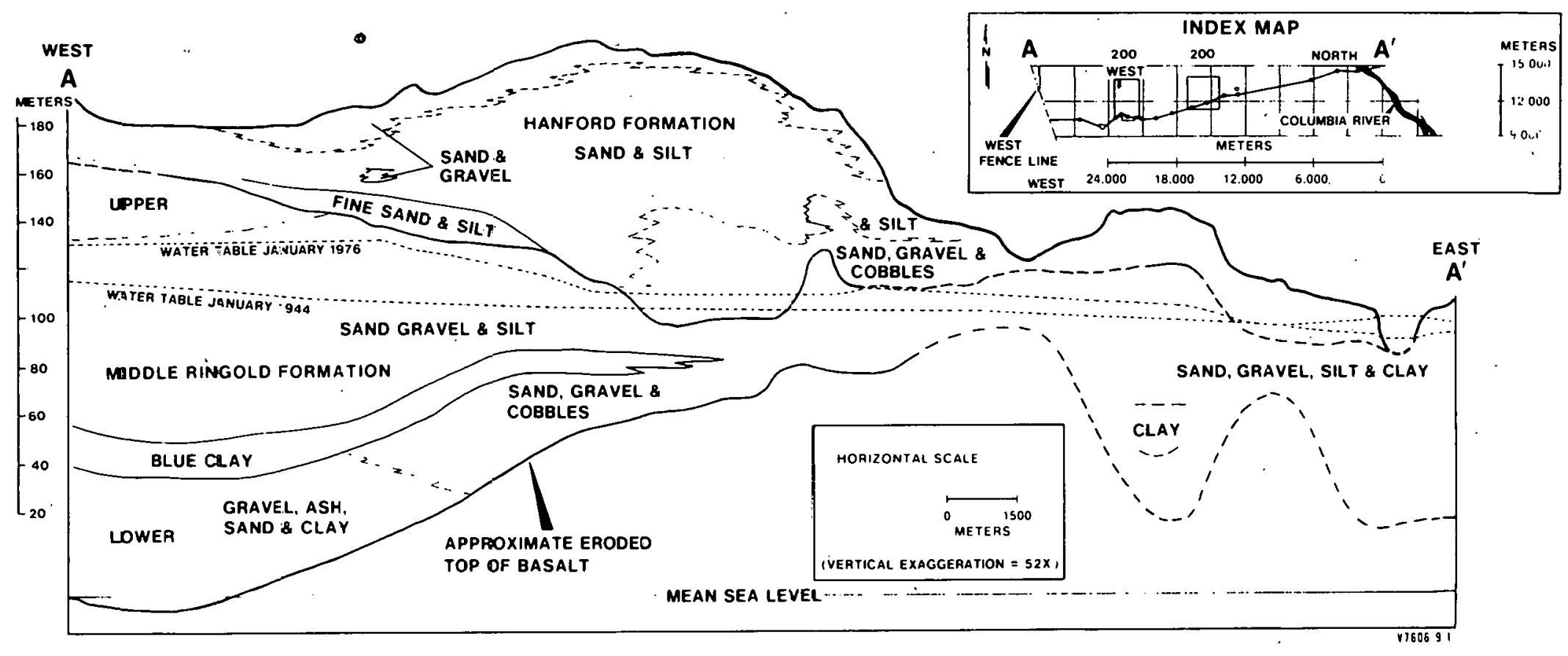

FIGURE 7.7 


\subsubsection{Basement Rocks}

The basement rocks, those underlying the basaltic lava flows, are of uncertain composition. Certain rock types can be projected from the margins of the Columbia Basin 160 to 240 kilometers away and certain pre-basalt rocks can be locally inferred from the known general geologic history of the region. On these bases, and from data from the Basalt Explorer Well near Odessa, Washington, it is concluded that sandstones and shales comparable to the Swauk Formation of the Blewett/Swauk Pass areas of Washington may lie beneath the region. Recent maqnetotelluric surveys indicate a deep conductive section possibly representing these sediments. ${ }^{(4)}$ Beneath them are probably granitic rocks comparable to those in the Okanogan Highlands, the Snoqualmie Pass area of the Cascade Range, the Moscow Basin, Idaho, the base of the Basalt Explorer We11, and parts of the core of the Blue Mountains, Oregon. Granite rocks there were intruded into largely Paleozoic and early.Mesozoic metavolcanic and metasedimentary rocks, whose equivalents might occur beneath the Pasco Basin.

\subsubsection{The Columbia River Basalt Group (5)}

The Columbia River Basalt Group( 6$)$ is a layered mass of more than 200,000 cubic kilometers of tholeitic lavas covering an area of more than 150,000 square kilometers in parts of Washington, Oregon, and Idaho (Figure 7.3). $(7,8)$ This mass of basalt flows represents the accumulation of repeated eruptions from middle Miocene, approximately 16 million years before present, $(9,10)$ that filled a slowly subsiding basin (11) shaped planoconvex downward in cross section. (12) An estimated 80 percent of the volume of the Columbia River Basalt was emplaced during a 3-million-year volcanic pulse between 16 million years before present and 13 million years before present. (13)

In the Pasco Basin near the center of the area covered by the Columbia River Basalt (Figure 7.3), the minimum thickness of the basalt is approximately 1,500 meters. $(14,15,16)$ There, the Columbia River Basalt apparently overlies a series of older basalts ${ }^{(17)}$ of 0ligocene to Eocene age. (18)

The Columbia River Basalt was first studied by geologists of the U. S. Geological Survey (USGS) during the 1890's and 1900's who were 
evaluating the resources of the region, particularly the ground water resources. (19 to 28) subsequent workers studied basalt flow structures, dikes, economic geology, sedimentary units associated with the basalts, and the stratigraphy of the basalts. (29 to 37) During the early studies, the overall lithologic similarity of the basalts and lack of economic. incentive thwarted most attempts to stratigraphically subdivide the mass of basalt flows. But, from about 1940 to 1960 , some success was achieved using lithologic characteristics and stratigraphic sequence. ( 38 to 45 ) Then, from about 1960 to the present, 1ithologic characteristics and stratigraphic sequence have continued to be used, but have been augmented and, to some extent, supplemented by geochemical, petrographic, geophysical, and paleomagnetic analyses. Such analyses have provided data useful for identifying, distinguishing, correlating, and mapping both individual flows and groups of flows. $(6,14$ to 16,41 to 77$)$

The Columbia River Basalt Group has been subdivided into five formations. The lower two are the Picture Gorge Basalt and the Imnaha Basalt. The upper three formations, the Saddle Mountains (upper Yakima) Basalt, the Wanapum (middle Yakima) Basalt, and the Grande Ronde (lower Yakima) Basalt, collectively constitute the Yakima Basalt Subgroup. These formations are, in turn, subdivided into various members and flows.

The Saddle Mountains and Wanapum basalts are laterally extensive units covering hundreds of square kilometers $(78,79)$ which have chemical variations related to stratigraphic position. (58) In the Grande Ronde Basalt, much less is known concerning the nature of intraflow and interflow chemical variations and the lateral extent or shape of individual flows.

Interpretations of deep structures within and beneath the Columbia River Basalt have been made using geologic, seismic, gravity, aeromagnetic, and resistivity studies. ( 80 to 86 ) The Columbia River Basalt thins toward the edges of the basin, $(6,87,88)$ resting unconformably on Mesozoic granitic rocks of the Okanogan Highlands to the north (Figure 7.1), on pre-Cambrian to Mesozoic rocks in the Rocky Mountains to the east, and mainly on folded Tertiary formations in the Blue Mountains and Cascade Mountains to the south and west. West-to-northwest-trending anticlinal ridges $(25,45)$ grew above the 
floor of the aggrading basin during the waning stages of volcanism. (87) Broad synclinal basins formed between these anticlinal ridges (Figure $7: 3)$.

Sufficient data are available within the upper 300 meters of the sequence to indicate that most of the flows in the western part of the plateau were moving northward or westward when emplaced. Dike swarms in northeastern Oregon and southeastern Washington were the vents for many of the flows. The presence of these dikes and vents suggests that others may have been buried by later flows within the Pasco Basin; none have been identified definitely, however.

The yrunger hasalt flows generally advanced northwest acruss tlie Pasco Basin and were deposited in an off-lap relationship against the plateau margins, the effect of the continuing regional subsidence and resulting opposed gradient. Many of the flows appear to have been emplaced as laterally extensive sheet-like lavas, perhaps as single flow units. Other flows divided into flow units, whereby separate tongues, gushes, or spurts of lava emerged from the main flow, progressively overrode one another as they were emplaced. Still other flows, especially some younger flows, flowed into valleys and spread locally.

\subsubsection{Ellensburg Formation}

Within the upper part of the basalt sequence, sedimentary units are increasingly abundant upward. These sediments include tuffs and tuffaceous sediments of many kinds, in part now altered to clay, form the Ellensburg Formation. Many basalt flows above the Vantage Sandstone horizon are capped locally by stream-deposited sediments. The extent and thickness of the sediments generally increase upward in the section.

About 15 milition years ago, ancestral river systems were crossing central Washingtion laying down trains of gravels, sands, silts, and clays comparable to today's sediments of the Columbia and Snake rivers. As the basin subsided, the river returned by gravity to the basin center leaving its sediment trains as a mark of its earlier courses. East of the current course, river sediments are virtually nonexistent between basalt flows attesting to the shifting only westward from the current basin center. 


\subsubsection{Ringold Formation}

The Ringold Formation ( 89 to 91) was deposited in response to a flattening of the gradient of the Columbia and Snake rivers systems, perhaps related to the uplift of the Horse Heaven Hills, and consequent deposition of the sediments it carried. Previously, deformation of the basin was accompanied by basalt flow extrusion into the topographically and structurally low areas. Cessation of flows about $8 \mathrm{million}$ years ago permitted the deposition of a continuous sequence of sediments. Initially, these were blends of up-river rock types derived from the Rocky Mountain foothills to the east, North Cascades, and,the Okanogan Highlands; with volcanic debris, largely of andesitic composition, from the central and southern Cascades. These latter sediments were transported to the Pasco Basin by the ancestral Yakima and related rivers. With time, the composition of the sediments being deposited in the Pasco Basin became more and more that of the Okanogan rock type.

The beginning of anticlinal uplift, especially to the west and slightly prior to the emission of the latest basalt flows, locked the Columbia River into the Pasco Basin and halted its east-to-west migration. Somewhat later, uplift of the Horse Heaven Hills resulted in a continuously rising base level for the river and deposition of sediment. Today, the Ringold. Formation is recognized only upstream of the Horse Heaven Hills, reflecting the control of deposition by those hills.

The Ringold Formation, which is Pliocenc in age, ${ }^{(92,93)}$ arbitrarily has been divided into a lower blue clays unit, a gravel or conglomerate unit, and an upper sand-silt unit. The division is unrealistic for the Pasco Basin as a whole, however. Sands, silts, clays, and gravels are interbedded and interlayered throughout the basin in a manner indicating a nearly continuous stream flow and continuous fluvial deposition. Even the lowermost silts and clays actually occur as a sequence of beds in different stratigraphic positions largely linked together to form a semi-continuous blanket over the basalts in the basin renter. Only locally do they suggest true lake deposits.

\subsubsection{Palouse Soils}

An eolian silt (loess) and fine sand overlie part of the eroded surface of the Ringold Formation and caliche bed beneath the western part 
of the Hanford Site. (94) It is considered to be the equivalent of the Palouse soils (loesses) of eastern Washington and western Idaho. It indicates a climate comparable to that of today, with effective wind transport and deposition of sediment.

\subsubsection{Hanford Formation (informal name)}

The Ringold Formation and the basalts and sedimentary interbeds were eroded and truncated by multiple floods that occurred as ice-dammed lakes released catastrophic torrents of water and ice when the ire dams were breached near the close of the ice age. $(95,96)$ The floods scoured the land surface, leaving a network of buried channels crossing the Hanford Site filled with the outwash sands and gravels.

The glaciofluvial sediments in the Pasco Basin were deposited on the Columbia River Basalt Group and Ringold Formation: These sediments can be divided into the coarser sands, gravels, and boulders and are referred to as the Pasco Gravels; the fine-grained sand and silt units are called the Touchet Beds. (97)

The Touchet Beds represent low-energy (slack water) deposits in Glacial Lake Lewis, which formed when flood waters were backed up behind the Wallula Gap constriction. The Pasco Gravels represent higher energ.y deposition in areas of more rapid water flow. In general, the Touchet Beds are found on the margins of the basin and the Pasco Gravels in and near the center of the basin. The characteristic variability of sediment size and degree of sorting within the "gravel" unit can be attributed to changes in water velocity and water level which occurred during the flooding process. The thickness of the Hanford formation varies significantly within the basin, with the thirkest. ncrurrence in the region of burind rhannels.

\subsubsection{Volcanic Ash Deposits}

Several volcanic ash falls were deposited in the late Pleistocene and Holocene period which are present in the Pasco Basin sediments. The thin, but widespread Mount St. Helens Set $S$ ash associated with the last flood was dated by Mullineaux, et al.,(98) at about 13,000 radiocarbon years before present. Other younger ashes, such as those from Glacier Peak, 12,000 years before present,(99) and Mazama, 6,600 years before present, have been found in the basin where the environment was favorable for preservation. 


\subsubsection{Eolian Deposits}

Loess and sand dunes mantle the surface of the Pasco Basin. $(100-102)$ These deposits are primarily reworked sediments of the Hanford formation from surrounding areas. The thickness of the wind-blown sediments varies considerably, ranging from zero to more than 30 meters in some dunes.

\subsubsection{Structure}

\subsubsection{Folds}

The most prominent structural features in the Hanford Site vicinity are the folds in the Columbia River basalts. Folding has divided the Columbia Basin into several sub-basins and produced numerous anticlinal ridges. Although the orientation of the folds is generally east-west, they can be classified into three general orientations: (a) east-westtrending; (b) west-northwest-trending; and (c) northeást-trending.

a. East-West-Trending Folds--The Toppenish anticline, Wapato syncline, the western portion of the Rattlesnake anticline, Moxee syncline, and Yakima anticline make up an asymmetrically folded ridge system with steep north slopes and gentle south slopes. The Saddle Mountains, Frenchman Hills, and Soap Lake anticline are north and east of this fold system and are also asymmetrical with the steep dips on the north slopes.

b. West-Northwest-Trending Folds--The eastern portion of the Horse Heaven Hills and the Rattlesnake Hills, Umtanum Ridge, and Manastash Ridge-Hanson Creek anticlines all trend west-northwest with steeply dipping north slopes. Gable Butte and Gable Mountain appear to be an east-west extension of Umtanum Ridge. Kittitas, Wenas, Wahluke, and. Cold Creek are west-northwest-trending synclines. The Cold Creek and Wahluke synclines underlie the Hantord Site. 
c. Northeast-Trending Folds--The Columbia Hills, the western portion of the Horse Heaven Hills, and the Beezley Hills are all northeasttrending anticlines. The Horse Heaven Hills anticline is asymmetrical with a steeply dipping north slope and a gently dipping south slope. The Beezley Hills anticline reflects generally the same asymmetry, but the crest is very winding and is offset by minor faults and cross-folds. (104)

\section{3. ¿̈. la aulls}

The faults mapped in the Hanford Site vicinity are associated with : folds in the basalt and appear to reflect local adjustments to folding. They are relatively short in length, with generally small displacements. In most cases, the major faults are less than 50 kilometers in length. The offset is generally less than 150 meters, $(105,106)$ but Gardner (107) has found an offset of 300 meters of vertical movement in the Wallula Gap fault. There are very few geomorphic features which can be attributed to recent fault activities, with a possible exception being the triangular facets to the east of the Columbia River along the Wallula Gap fault. The faults and associated anticlinal folds of significance to the site are listed below and shown in Figure 7.8.
a. Wallula Gap fault and Rattlesnake Hills anticline.
b. Umtanum fault and anticline.
c. Gable Butte and Gable Mountain and two minor faults.
d. Manashtash-Hanson Creek fault and anticline.
e. Saddle Mountains fault and anticline.(103)

\subsubsection{Tectonic Structures}

\subsection{Gable Mountain}

Gable Mountain is located in the central portion of the Hanford Site (Figure 5.2) and is made up of two en echelon-plunging anticlines separated by a synclinal trough. The eastern anticline is asymmetrical with a steep north slope and the western anticline is asymmetrical with a 


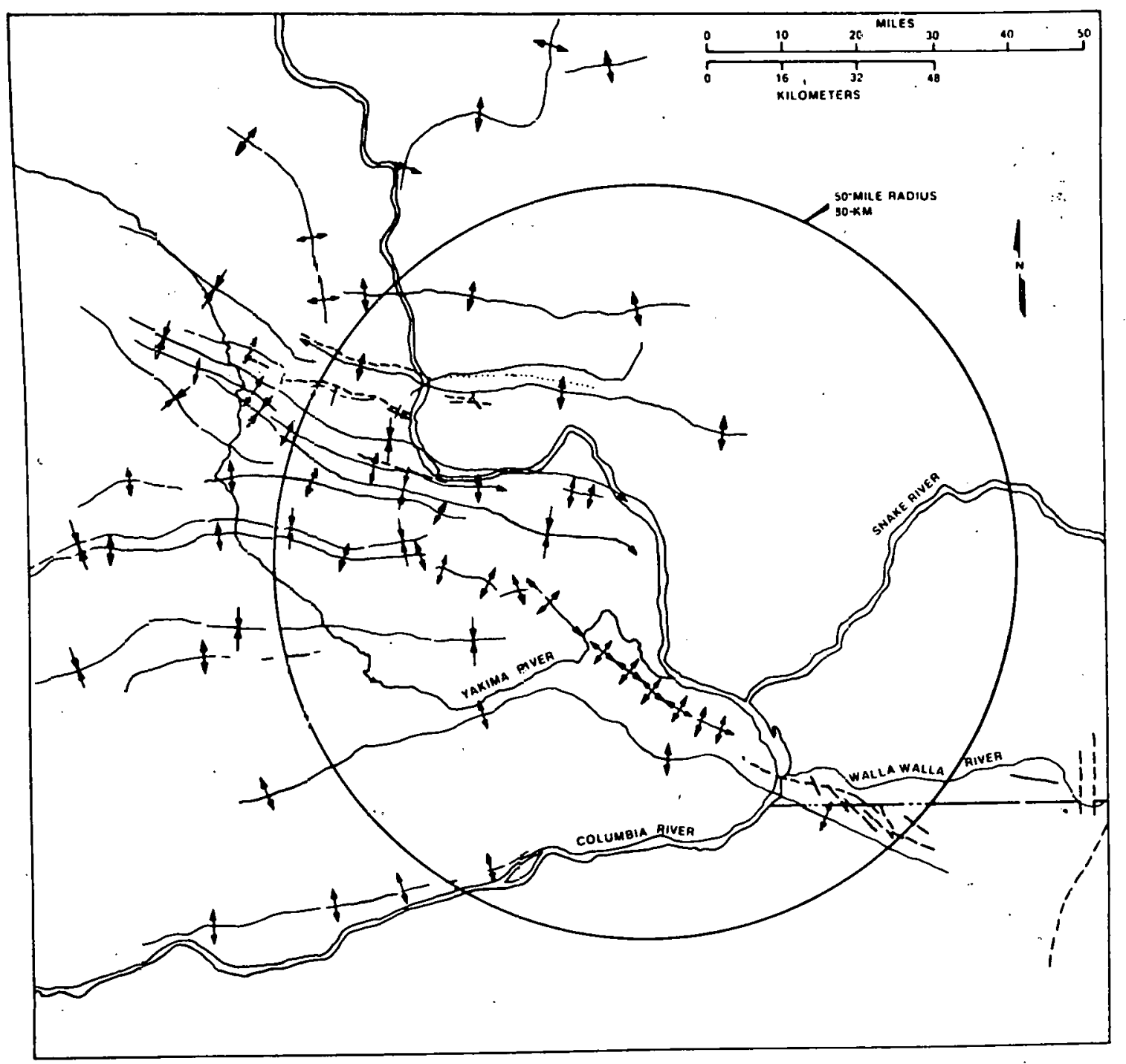

FIGURE 7.8

\section{SYMBOLS}

GEOLOGIC CONTACT APPAOXIMATELY LOCATEO

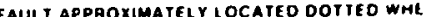
CONCEALED OUESTIONED WHE AF IMFE HAEO

1 aXIS OF ANTICLINE AHROW SHOWS DHFEC CIION

7 AXIS Of AN

1 axis of SYMCLINE AXIS SHOWS OiAECTION PLUNÉ

LOCATION OF GE OLOCY PROFILF IN THE 
steep south slope. A fault on Gable Mountain appears to be of the same period as the folding and has a stratigraphic displacement of 20 meters or less. Glaciofluvial deposits overlying this fault were radioactive carbon-14 dated as being more than 40,000 years old. No displacement by faulting could be found in these sediments. (106)

\subsection{Gable Butte}

Gable Butte is located in the central portion of the site, west of Gable Mountain (Figure 5.2), and is made up of three en echelon anticlines which are gently and symmetrically folded. A fault was postulated to be near the west end of Gable Butte by Jones and Deacon. (108) Subsequent investigations by Bingham, et al., proved that no fault existed at that location. (106)

\subsection{Umtanum Ridge}

The Umtanum Ridge anticline extends for about 80 kilometers in a northwesterly-by-southwesterly direction (Figure 7.8). Umtanum Ridge plunges into the Pasco Basin toward Gable Butte and Gable Mountain. 'The easternmost 14 kilometers were mapped by WPPSS(103) and this segment "... is asymmetrical to the north with a steeply dipping and locally overturned north siope."

To the northwest, Umtanum Ridge is sharply folded into a steep monocline with shear zones of fractured basalt running subparallel to the axis of the monocline.(109) These structures trend eastward beneath Lhe Hanford Site. Several faults were identified by Mackin(11) on the north limb of the anticline in the vicinity of Priest Rapids Dam. A promincnt high-angle reverse fault has been traced for about 3.2 kilometers southeast of the Priest Rapids Dam and inferred for another 6.4 kilometers. No evidence of faulting has been detected in the Hanford formation along the inferred trace of fault activity. $(103,109)$

\subsection{Saddle Mountains}

The Saddle Mountains anticline is an asymmetrical fold with steeply dipping and overturned north limbs (Figure 5.2). Faults have been mapped on both the north and south side of the Saddle Mountains. $(76,104,106)$ A 
high-angle fault has been traced along the north limb of the Saddle Mountains through a series of widely spread outcrops over a distance of 67 kilometers.

Several small faults on the south side of the Saddle Mountains were found to have no more than 15 meters of vertical offset. These features are at least pre-Holocene in age. (103)

\subsection{Yakima Ridge}

The Yakima Ridge anticlinal system is approximately 50 kilometers long and extends from the Pasco Basin to the city of Yakima. WPPSS ${ }^{(103)}$ mapped about 50 square kilometers at the eastern end of the ridge and found it to consist of 3 asymmetrical anticlines. Two small faults were mapped on the south limb of the southernmost anticline. A reverse fault was traced for 244 meters; it then turned eastward for an additional 366 meters. There is no surface expression of the fault in the Touchet sediments where the fold axis plunges into Dry Creek Valley.

The second fault trends obliquely to the reverse fault and is inferred for 300 meters from an isolated breccia outcrop. Both faults are interpreted to be adjustment faults associated with the folding of the tightly folded anticline.

\subsection{Rattlesnake-Wallula Lineament}

The Rattlesnake-Wallula lineament is a portion of the 0lympic-Wallowa Lineament (OWL) of Kaisz. (110) The l1neament canl be traced from the Olympic Peninsula to the Wallowa Mountains. The OWL is not a sharply defined or continuous structure. The portion of the lineament along the Rattlesnake Hills to Wallula Gap is referred to as the RattlesnakeWallula lineament and is shown in Figure 7.8. The Horn Rapids alignment, the Badger Coulee alignment, and the Horse Heaven Hills anticline (Figure 7.8) are structures subparallel to the Rattlesnake-Wallula lineament.

Faults have been mapped in the Rattlesnake-Wallula lineament. In general, they can be related as anticlinal deformations. The Wallula Gap fault (Figure 7.8 ) is a zone of normal faulting in the Columbia River Basalt with an offset of 300 meters at the southern end of the Rattlesnake-Wallula lineament. Horizontal slickensides on the high- 
angle, locally reversed fault suggest the last movements were strike slip. There was no conclusive evidence of deformation found in the over lying Quaternary sediments. (109)

To the northwest of the Wallula Gap fault, there are brecciation zones on many of the en echelon, doubly plunging anticlines. These have been cited by Blume and Associates, (111) Swanson, et al., (112) Jones and Deacon, (108) WPPSS, (103) ARHCO, ${ }^{(46)}$ and others. The structures are blanketed with loess and outcropping is limited.

\subsection{MINERAL RESOURCES}

\subsubsection{Water}

Water, the most extensively used resource in the Pasco Basin, is pumped from the Columbia, Yakima, and Snake rivers and from ground water wells for domestic and irrigation usage. Ground water is pumped from wells penetrating the unconfined system and from wells drilled into interbeds and interflow zones in the Columbia River Basalt Group and Ellensburg rormation.

\subsubsection{Sand and Gravel}

Sand and gravel are widespread throughout the Hanford Site. They are largely used bv the building and construction industries for concrete, aggregate, macadam, and fill. Sand and gravel is mined from numerous open pits on the Hanford Site.

\subsubsection{Basalt}

Basait forms the bedrock in the Pasco Basin and is present on Rattlesnake Mountain, Gable Mountain, and Gable Butte within the Hanford Site. Basalt is primarily used in road construction for surfacing, in macadam, as ballast, and as asphalt aggregate. Several basalt quarries are currently active on the north flank of Rattlesnake Mountain and the west end of Gable Mountain. 


\subsubsection{Gas (113)}

Gas was produced from wells in the Rattlesnake Hills Gas Field on the north $f l a n k$ of Rattlesnake Mountain. The field was in commercial production from 1929 to 1941. Production came from 2 zones in the basalt at depths of approximately 213 and 366 meters. The gas was a high-methane type ( 99.35 percent) and did not contain the heavier fractions that are commonly associated with a petroleum-derived gas. The source of the gas is not known, but may have originated as the result of decay of vegetal matter in the inter-basalt sediments. Gas, other than minor amounts, has not been encountered during recent drilling of deep boreholes in the basalt on the Hanford Site.

\subsubsection{Other Mineral Resources}

Diatomite, pozzolan, and clay have been mined from open pits in the Pasco Basin, but not on the Hanford Site. The economic value and extent of these mineral resources are not known. 


\subsection{SEISMOLOGY OF THE HANFORD SITE AND ADJACENT AREAS}

\subsection{EARTHQUAKE HISTORY}

The Columbia Basin, including the smaller structural unit, the Pasco Basin, is an area of low seismicity in which moderate-level earthquakes (Modified Mercalli [MM] intensity SVII have occurred. While the historical record of earthquakes is relatively brief, it is sufficiently long to indicate that this area of eastern Washington has experienced fewer earthquakes of generally lower level than areas in the Puget Sound-Willamette lowland of western Washington or the Rocky Mountains. The Pasco Basin contrasts markedly with zones of higher seismicity to the west and east. (1) A summary of recent western Washington earthquakes is presented below.

\section{TABLE 8.1}

\section{RECENT WESTERN WASHINGTON EARTHQIIAKE.S}

DATE

November 12, 1939

April 29, 1945

February 14, 1946

April 13, 1949

April 29, 1965

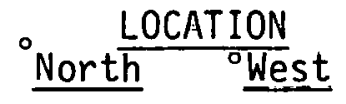

47.5

47.75

47.5

47.25

47.4
EPICENTRAL INTENS ITY

(MM)

VIII

VII

VII

VIII

VII-VIII
DISTANCE TO SITE (kilometers)

249

215

249

$194^{\circ}$

238

Note: Center of Hanford Site is located at approximately 46 degrees North and $119.5^{\circ}$ degrees west.

These earthquakes attenuated rapidly eastward so that the maximum known intensity in the vicinity of the Hanford Site was MM $\leq$ IV. (2)

A network of seismographs was established in eastern Washington and has been operational since March 1969. Without this dense network of 
recorders, most events that have been recorded in this period would have gone undetected because of: (a) relatively low population density; (b) small area in which the shock occurred; (c) low levels of stress release that are not generally felt by humans; and (d) too great a distance from the network of established stations prior to 1969. Some spatially and temporally restricted swarms have occurred, but the distribution of earthquakes generaliy indicates that stress release is low, infrequent, and not concentrated in planar zones suggestive of fault activity (Figure 8.1).

A large earthquake occurred at about 10:40 p.m. on December 14, 1872 in a sparsely populated area of northern Washington and southern British Columbia. Because of scarce data, details of this earthquake are not well established. A massive research effort was conducted by Washington Public: Power Supply System, Inc. (WPPSS) to determine the epicenter and epicentral intensity of this earthquake, along with any possible relationship to the geologic structure. This research was undertaken in the preparation of preliminary safety analys is reports and amendments thereto for several commercial light water reactor units located on the Hanford Site. The research included detailed geologic mapping in the epicentral area, as well as in the region; (3) analysis of imagery, $(4,5)$ compilation and review of contemporary accounts of this earthquake by WPPSS and independent consultants, $(6,7,8)$ ' geophysical investigations, $(9,10)$ development of a plate tectonic model for the Pacific Northwest, (11) and analys is of both macro- and microearthquakes. $(7,12,13)$ Some of the conclusions reached by a review panel on the 1872 earthquake are: (14)

a. The epicenter was located in the North Cascades-0kanogan area within a zone extending from Lake Chelan in the south to southern British Columbia in the vicinity of Chilliwack; the epicenter was not in the Columbia Basin in any case;

b. Contemporary accounts suggest that a few aftershocks of smaller magnitude occurred during the night after the main shock, which happened about 10:40 p.m.; these aftershocks occurred over a broad. 


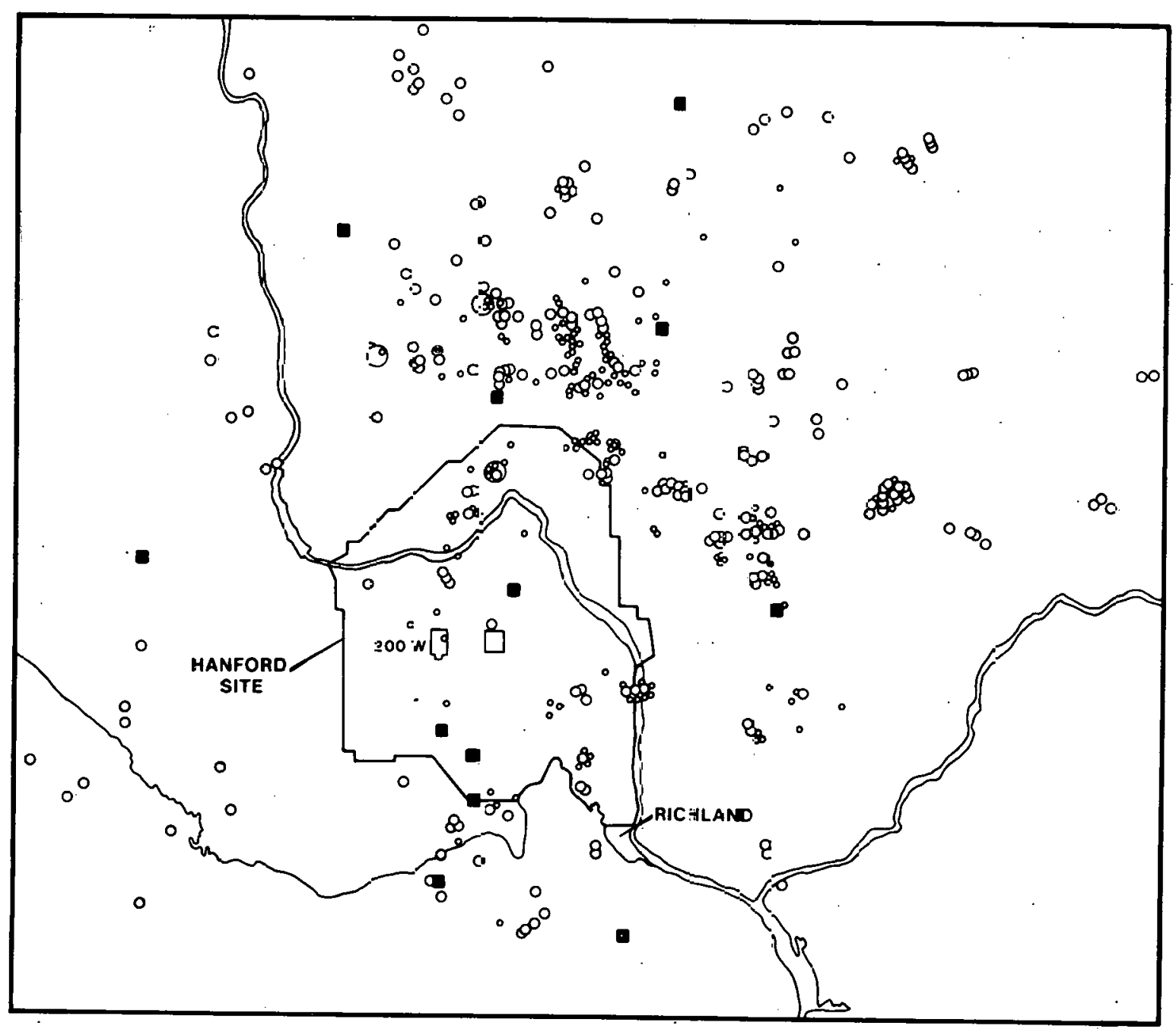

FIG:JRE 3.1

MICROEARTHQUAKE EPILENTERS; HANFORD SITE REGION

\begin{tabular}{|c|c|c|}
\hline $\begin{array}{l}\text { MAGNITUDE } \\
\text { (RICH'ER } \\
\text { SCALE) }\end{array}$ & $\begin{array}{l}\text { LESS THAN } \\
10 \\
\text { KILOMETERS }\end{array}$ & $\begin{array}{c}\text { FOCAL DEPTH } \\
\text { GREATER THAN } \\
10 \\
\text { KILOMETERS }\end{array}$ \\
\hline 3.0-3.3 & 0 & ש \\
\hline $1.0-25$ & 0 & • \\
\hline $0.1-0.5$ & 。 & - \\
\hline
\end{tabular}

v1606.9.7.

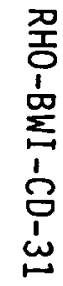


area initially and may, in part, account for the large area in which the event was felt and assumed to be the result of just the main event;

c. A wide-felt area may be the result of the main shock only or the cumulative effect of the main shock plus seemingly widely scattered aftershocks; since the records are not adequate to distinguish between these two possibilities, all that can be said is that there is a broad area in which effects corresponded to MM VIII; the epicenter was probably within this broad region; surface faulting compatible with an 1872-type event has apparently not occurred in the Columbia Plateau (Basin) in the last 11,000 years;

d. Since this was probably a deep crustal event of about 38 kilometers focal depth, the probability is very remote that it could have occurred, or could occur, in the Columbia Plateau, where the crust is 1 imited to a thickness of 24 kilometers; an earthquake that occurred at a focal depth of 38 kilometers in the Columbia Basin would have been generated in the mantle;

e. Structures in basement rocks along the margin of the Columbia Plateau do not appear to have affected thin Columbia River basalts and overlying sediments that are younger than mid-Pleistocene in age (i.e., there appears to have been no deformation of Columbia River basalts in the last 1 million years); geologic and aeromagnetic investigations along the margins of the Columbia Basin disclosed no evidence of late Quaternary deformation. (15)

Since the December 14, 1872 earthquake is of potential significance to the proposed Hanford, Pebble Springs, and Skagit nuclear generating stations, a number of hearings and reviews were conducted after submission of WPPSS Ameridment 23 to the U. 3. Nuclear Regulatory Commission (NRC) in October 1977. Joint hearings involving members of WPPSS, Portland General Electric, Puget Sound Power and Light, NRC, Advisory Committee on Reactor Safeguards, and the USGS were conducted. As a result of these meetings and reviews of new information on the 1872 
earthquake, the USGS and the NRC reevaluated the geology and seismology pursuant to the design of these proposed nuclear facilities. The USGS concluded that: (a) the 1872 earthquake was probably an intensity MM IX because of the numerous landslides reported; (b) an earthquake similar to the 1872 event will not occur on the Columbia plateau, but could occur along the margins of the plateau; and $(c)$ a $0.25-\mathrm{g}$ zero-period horizontal ground acceleration was appropriate for design of WPPSS Units 1 and 4. (16)

The NRC concluded that: (a) the Columbia Plateau is a unique. tectonic province within the context of Appendix $A$ to Chapter 10 of the Code of Federal Regulations, Part 100 and is distinct from the area in which the 1872 earthquake occurred; ${ }^{(17)}$ (b) an event similar to the 1872 earthquake need not be considered near WPPSS Units 1 and 4; (c) a zero-period horizontal ground acceleration of $0.25 \mathrm{~g}$ is appropriate for design of WPPSS Units 1 and 4 , as earlier stated in the safety evaluation report; ${ }^{(18)}$ and (d) the 1872 earthquake should be considered a "strong intensity MM VIII," based on the absence of evidence other than landslides (which have occurred at much lower intensities).

While many details relating to the 1872 event remain uncertain, the recent investigations summarized above indicate that this event was generated in an area at least 160 kilometers northwest of the site in a sparsely populated area that is geologically different from the Columbia Basin. The epicentral intensity was probably MM VIII, but the site apparently experienced effects corresponding to a maximum MM VI, (14) Geologic investigations indicate that surface faulting apparently did not occur during this earthquake. Therefore, the potential for recurrence of a similar sized event or the potential for surface faulting during an earthquake in the Columbia Basin seems remote.

\subsection{CORRELATION OF EPICENTERS WITH GEOLOGIC STRUCTURES}

There is no well-defined relationship between macroseismicity and geologic structure in the Columbia Basin or anywhere in the region of the site. Most stress release in the region of the site is concentrated in the Puget Sound-Willamette lowland of western Washington where some moderate to large earthquakes of focal depths of 57 kilometers have occurred in the past 40 years. 
This broad topographic low is filled with many hundreds of meters of unconsolidated sediments that bury any structures present in the bedrock along which earthquakes may have occurred. Stress in this area may be relieved along the dipping boundary of the already subducted Juan de Fuca Plate near the area where the angle of descent changes from about 14 degrees to about 40 degrees. (15) Lengthy strike-slip faults, such as the Straight Creek, Ross Lake, and Pasayten faults along which lengthy displacement apparently occurred in Late Mesozoic to Early Tertiary time, are found to the east of the Puget Sound-Willamette lowland and do not appear to be the focus of present stress release.

The July 15, 1936 MM VII Milton-Freewater earthquake occurred 48 $k i l o m e t e r s$ east of the area where the extensions of the northwesttrending Horse Heaven Hills and Rattlesnake-Wallula structures, along with projected extension of the Wallula Gap fault, merge (Figure 7.7). The northeast-trending Hite fault also occurs in this area. Cracks in the ground were reported in the epicentral area and near Walla Walla. (19) Both areas are underlain by thick sequences of unconsolidated sediments. The nature of these reports suggests non-tectonic deformation, especially along the edges of slopes artificially excavated for a highway or a railroad. Several aftershocks of this earthquake suggest that the plane of rupture was oriented northeast, an alignment that agrees with that of the Hite fault and the Blue Mountains uplift. The felt area and isoseismals also display an elungation in a northeast direction. $(2,19)$ It is not certain whether this earthquake occurred along any of the mapped structures in the area. Since it is the only recorded MM VII or greater earthquake within a 120-kilometer radius of the center of the Hanford Site, it is unique. In the absence of surface faulting or a fault plane solution, the northeast-trending zone of aftershocks and the northeast-trending felt area suggest a relationship to the Hite fault, an association that is not proven.

Various interpretations have been given to the steep slopes on the north and northeast sides of anticlinal ridges such as Horse Heaven Hills, Rattlesnake Mountain, Saddle Mountains, and Gable Mountain. A 
relatively thick blanket of loess and other unconsolidated deposits covers the bedrock in many critical areas, complicating the observation and interpretation of these zones of steep slope. Whether the apparent stratigraphic offset of basalt units is due to folding, faulting, or some combination of the two is not clear. $(2,20$ to 22) At some localities, (23) outcrops clearly expose a fault, but because of a cover of unconsolidated sediment, it not possible to trace the structure any distance laterally. In other exposures, the rocks are clearly folded and not faulted, but the lateral extent of the structure has not been determined. The two processes seem to be related, as suggested by the strike of folds and faults. Large blucks of basalt have sind downslope as a result of non-tectonic slope processes and these further compound the problem of interpretation. Recent interpretations suggest that these steeply dipping northern flanks may not be continuous structures in length, but rather a composite of several segments, each of which may. have behaved independently. (2) Sediments of less than 15 meters in thickness interbedded between basalt flows are commonly sheared along their margins in the areas where dip changes abruptly. : Such shearing would be expected where materials of different mechanical properties slide past one another in the process of flexure-slip folding. (23) In some instances, delicate primary sedimentary structures such as ripples are well preserved in the central part of interbeds, suggesting that the shearing is confined to the margins of the bed as would be expected in the flexure-slip folding process. In other cases, the shcaring appears to be more pervasive, suggestive of fault gouge. For the most. part., the interbeds are concordant with the stratification in the basalts, suggestive that faulting has not occurred. However, in at least one locality, an. interbed terminates abruptly against basalt with a marginal zone of shearing separating the two lithologies. (24) Large landslides that have displaced large blocks of some of the units on the north sides of these ridges complicate the interpretation of the structure.

With one exception, neither macroearthquakes (larger than magnitude 3.0) nor microearthquakes appear to align along any of the northwest-trending zones of steep slope on the north sides of these anticlines. A MM V-VI earthquake that occurred on November 1, 1918 near 
the town of Corfu has been tentatively located along the Saddle Mountains structure (Figure 7.8). The location and size of this event are poorly known. Corfu, the reported epicenter of this event, lies along an extension of a shear zone in basalts along the front of the Saddle Mountains some 24 kilometers to the west. This shear zone has been interpreted as the Saddle Mountains fault. (22) A large block slide has occurred in the vicinity of Corfu. The evidence for association of the Corfu earthquake with the Saddle Mountains fault is equivocal. Subsidence, originally interpreted as a graben produced during the 1918 earthquake $^{(20)}$ has more recently been interpreted as a landslide. Chimneys and doorframes of brick structures built prior to this event were not damaged during the earthquake.

Microearthquake activity that has been monitored continuously in the Columbia Basin since March 1968 (first by the USGS and later by the University of Washington with an expanded network), indicates:

a. Low levels of stress release;

b. Generally shallow focal depths ( $<8$ kilometers);

c. No obvious relationship to any mapped geologic structure;

d. Except for swarm activity, stress release does not appear to be concentrated in any zone; even within the area of a swarm, there appears to be no concentration of events along planar zones.

Swarm activity has been recorded at Wooded Island and there have been clusters of events in time within controlied zones. Unlike the situation in California, where segments of the Hayward, San Andreas, and Calaveras faults are clearly delineated by microearthquakes, there is nn clustering, concentration, or alignment of microearthquake epicenters along any of the mapped nnrthwest-trending structures in the Columbia Basin. 


\subsection{IDENTIF ICATION OF CAPABLE FAULTS}

In the absence of definitive evidence, the Rattlesnake-Wallula lineament, the longest structure in the vicinity of the Hanford Site, is assumed to be capable. Even though there is no alignment of earthquakes to support this hypothesis, the feature is considered capable of generating an earthquake of MM VII--larger than any known event within 100 kilometers of the Hanford Site. Because exposures along the Rattlesnake-Wallula lineament are separated by some distance, it is not clear whether the observed evidence of faulting seen at separated lucalilies (26) is part of a continuous structure, or a composite of segments. Research presently under way may indicate the nature and extent of the zones of steep slope at the north end of each of the asymmetrical anticlines in the area.

\subsection{MAXIMUM HISTORIC EARTHQUAKE}

The largest earthquake known to have occurred in the Columbia Basin is the July 15, 1936 state-line earthquake with an epicenter in the viciniy of Milton-Freewater in northeastern Oregon. This earthquake had a maximum epicentral intensity of MM VII. (19) Since it occurred within the Columbia Basin and cannot be specifically related to a fault, it is assumed to have the potential to recur in the vicinity of the site. $(26)$ Using intensity/acceleration correlations of Neumann ${ }^{(27)}$ and Trifunac and Brady, $(28)$ the event corresponds to a zero-period horizontal ground acceleration of 127 centimeters per second squared or $0.13 \mathrm{~g}$. Using the intensity/acceleration correlation of Murphy and O'Brien, (29) this event corresponds to a zero-period horizontal ground acceleration of 100 centimeters per second squared or $0.10 \mathrm{~g}$.

The December 14, 1872 earthquake was the largest earthquake known to have occurred within 320 kilometers of the Hanford Site. The epicentral intensity of this event was MM VIII. (26) As this event occurred in a tectonic province other than the Columbia Basin, the earthquake has been moved to the point along the edge of the Columbia Basin that is closest to the site and attenuated to the site using attenuation curves appropriate for the region. This event attenuates to a MM VI at the site, an intensity which agrees with that shown on the isoseismal map for this earthquake. (14) 
Other earthquakes in the region, which have occurred in the Puget Sound-Willamette lowland, attenuate to MM IV or less at the site. (2)

The maximum earthquake felt at the site, based upon earthquake records and isoseismal maps, has been projected to have been MM VI, corresponding to the December 14, 1872 event. Since the July 15, 1936 MM VII Milton-Freewater earthquake cannot be unequivocally associated with any mapped geologic structure, it is conservatively assumed, in accordance with NRC procedures, to have the potential of recurring at any locality in the Columbia Basin even though no other event of this size is known anywhere in the basin. Therefore, the maximum earthquake that could be felt at the site, based upon earthquake records and tectonic province, is MM VII that was generated by the July 15, 1936 Milton-Freewater event. This allows for no attenuation over the 112 kilometers between the epicenter and the site, since the epicenter and the site are in the same tectonic province.

\subsection{SUMMARY}

The maximum earthquake projected to have been felt at the site is a MM VI from the December 14, 1872 earthquake in the North Cascades, as reported by Coombs, et a1. (6) A11 other events attenuated to intensities of MM IV or 1ess. Since the July 15, 1936 Milton-Freewater MM VII event occurred within the Columbia Basin and cannot be definitely associated with a causative fault, it is conservatively assumed to have the potential to recur anywhere in the Columbia Basin even though historic data indicate that no events larger than MM V-VI (November 1 , 1918 Corfu earthquake) have occurred in the center of the Pasco Basin.

In the absence of definitive evidence, the Rattlesnake-Wallula lineament is conservatively assumed to be a fault that could be active and that could generate a MM VIII earthquake. (2) Such an earthquake is not conclusively known to have occurred along the Rattlesnake-Wallula lineament, although the Milton-Freewater epicenter occurs along the projected extension of this feature and has been suggested as being associated with it. 
Using conservative practices of the NRC, as related to capable faults, the Rattlesnake-Wallula lineament is assumed to have the potential to generate an earthquake of MM VIII; i.e., one intensityhigher than may have occurred. The Rattlesnake-Wallula lineament is part of the OWL that Davis ${ }^{(11)}$ recently indicated to be a "fictional structural element" along a part of which some dextral strain may have occurred. This feature is apparently not the boundary between crustal materials of different character as earlier hypothesized. (30) 


\subsection{HISTORICAL AND ARCHEOLOGICAL SITES}

The National Register of Historic Places ${ }^{(1)}$ currently lists three historical sites within approximately 80 kilometers of the Hanford Site:

a. Marmes Rockshelter, located 1.6 kilometers north of Lyons Ferry on the west side of the Palouse River, Franklin County;

b. Olmstead Place State Park, 6.4 kilometers east of Ellensburg, near the Kittitas Highway, Kittitas County;

c. Whitman Mission National Historic Site, 9.6 kilometers west of Walla Walla, off U. S. Highway 410 , Walla Walla County.

The National Registry of Natural Landmarks ${ }^{(2)}$ lists two sites which are within 80 kilometers of the Hanford Site:

a. Ginkgo Petrified Forest, located in Kittitas County 46 kilometers east of Ellensburg;

b. Grand Coulee, located in Grant County between the towns of Grand Coulee and Soap Lake.

Many archeological sites of significance are found in the Hanford area. $(3,4)$ The Columbia River shoreline, from Vantage to the north downstream to Umatilla, is rich with Indian artifacts. Many campsites and fishing grounds within the site boundary were traditionally used as wintering areas from prehistorical times until the area was evacuated in 1943. Registered archeological sites within an 80-kilometer radius of the IMS are identified in Figure 9.1; the majority of these sites lie close to the Columbia and Snake rivers. Large portions of the land area at grcater distances frnm the rivers have never been surveyed for archeological sites. 


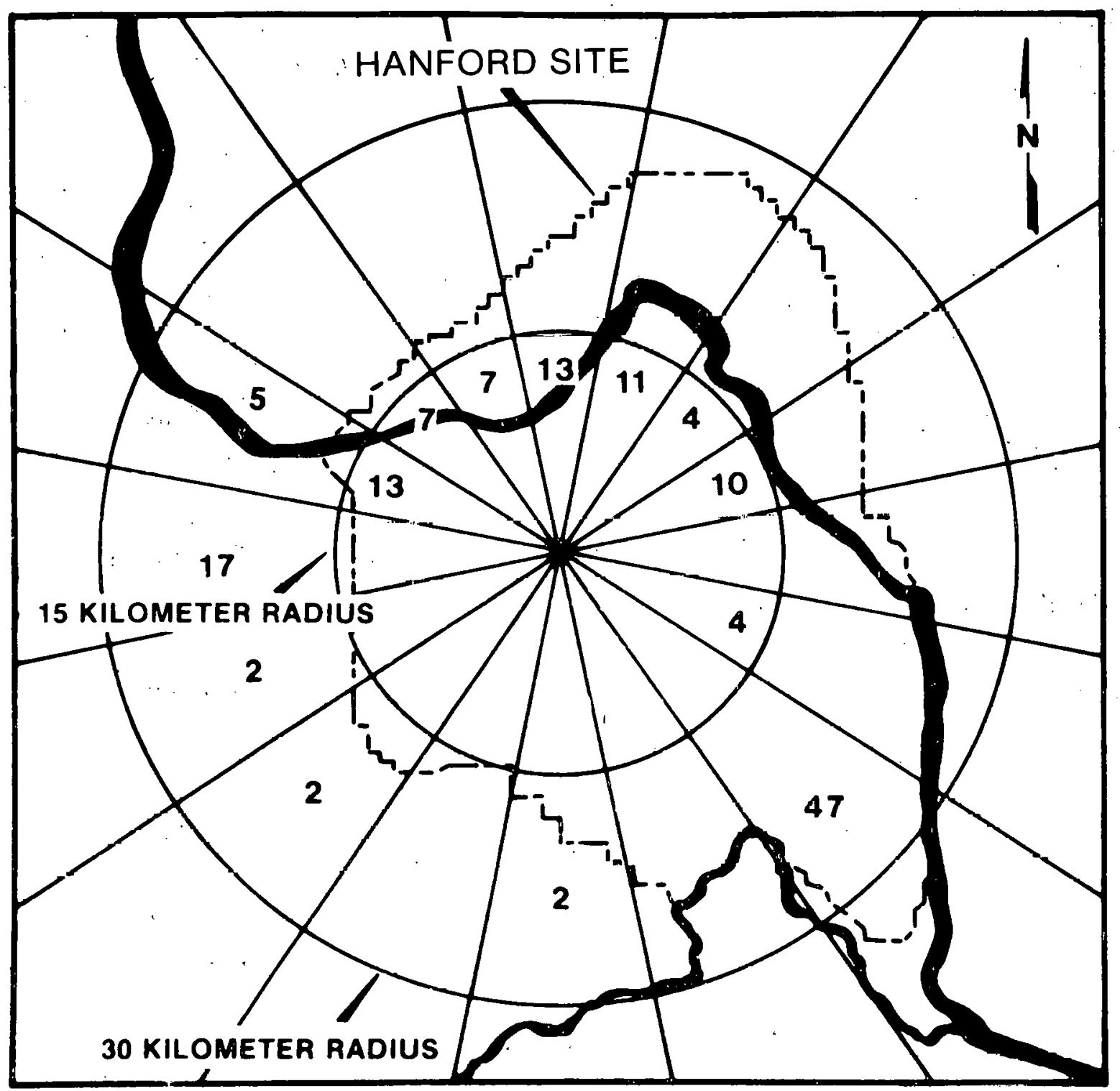

FIGURE 9.1

ARCHEOLOGICAL SITES ON AND NEAR THE HANFORD SITE 
The Columbia River was one of the most densely inhabited regions in aboriginal North America, and its inhabitants possessed one of the most interesting life ways of the continent. With the exception of the sites located on the Hanford reach of the Columbia River, evidences of this life way have been virtually erased. Therefore, the remaining sites assume great significance and are being evaluated. Field exploratory work is being conducted under a research grant by Dr. D. G. Rice, an archeologist formerly with Washington State University. 


\subsection{REFERENCES}

\section{CHAPTER $\quad 1.0$}

1. R. A. Deju, Basalt Waste Isolation Program Plan, RHO-CD-132 (REV 3) Rockwe1l Hanford Operations, Richland, Washington, May 1979.

2. Report to the Prosident by the Interageney Review Group on Nuc ledr: Waste Management, TID $=20017,1970$.

3. U.S. Department of [nergy, Enviruniminlal Impact Statement: Management of Commercially Generated Radioactive Waste, 'DOE-1559, Washington, D.C., 1979.

\section{CHAPTER 2.0}

1. D. J. Brown and R. E. Isaacson, The Hanford Environment as Related to Radioactive Waste Buria; Grounds and Transuranium Waste Storage

Facilities, ARH-ST-155, Atlantic Richfield Hanford Company, Richland, Washington, 1977.

2. U.S. Energy Research and Development Administration, Final Environmental Statement, Waste Management Operations, Hanford Reservation, Richland, Washington, ERDA-1538, 2, Washington, D.C., 1975.

3. J. R. Walker, State of Washington Population Trends, 1972, Information Systems Division, Office of Program Planning and Fiscal Management, Olympia, Washington, 1972.

4. Information Systems Division, Office of Program Planning and Fiscal Management, State of Washington, Population Trends, 1973, 01ympia, Washington, 1973. 
5. Information Systems Division, Memorandum, Interim, Population. Projections for Year 2000 by County, House Office Building, 01ympia, Washington, October 2, 1972.

6. 1970 Census of Population, U.S. Department of Commerce/Bureau of the Census, Washington, D.C..

7. Business Research Division, Pacific Northwest Bell Telephone Company, Population and Household Trends in Washington, Oregon, and Northern Idaho, 1970-1985, Seatt le, Washington, January 1972.

8. Bonneville Power Administration, U.S. Department of the Interior, Washington Population, Employment and Housing Units Projected to 1990, Washington, D.C., 1973.

9. Battelle, Pacific Northwest Laboratory, Population Distribution in 90-Mile Radius of Hanford Meteorological Station and Projection to Year 2300 by Compass Sector and 10 Mile Radii, BNWL-2178, Richland, Washington, 1976.

\section{CHAPTER 3.0}

1. U.S. Energy Research and Development Administration, Final Environmental Statement, Waste Management Operations, Hanford Reservation, Richland, Washington, ERDA-1538, 2, Washington, D.C., 1975.

2. G. G. Robeck, C. Henderson, and R. C. Pàlange, Water Quality Studies on the Columbia River, PHS, R. A. Taft Sanitary Engineering Center, 1954 .

3. J. J. Davis, D. G. Watson, and C. C. Palmiter, Radiobiological Studies of the Columbia River Through December, 1955, HW-36074, General Electric Company, Richland, Washington, 1956. 
4. D.C. Watson, C. E. Cushing, C. C. Coutant, and W. L. Templeton, Radioecological Studies on the Columbia River, Parts I and II, BNWL-1377, Battelle, Pacific Northwest Laboratory, Richland, Washington, 1970.

5. C. D. Becker, Aquatic Bioenvironmental Studies in the Columbia River at Hanford, 1945-1971, a Bibliography with Abstracts, BNWL-1734 Battelle, Pacific Northwest Laboratory, Richland, Washington, 1973.

6. R. W. Coopey, The Abundance of the Principal Crustaced of the Columbia River and the Radioactivity They Contain, HW-25191, General Electric Company, Richland, Washington, 1953.

7. J. F. Scarola, "Cladocera and Copedpoda in McNary Reservoir, 1965-66," Northwest Science, 42, 1968.

8. E. G. Wolf, T. L. Page, and D. A. Neitzel, "Phytoplankton Community; Primary Productivity, Pigment Concentration, Species Composition and Kelative Abundance of Phytoplankton and Physiochemical Analysis," Final Report on Aquatic Ecological Studies Conducted at the Hanford Generating Project, 1973-1974, prepared for Washington Public Power Supply System, Inc., under Contract Number. 2311-201335 with United Engineers and Constructors, Inc., Pacific Northwest Laboratory, Richland, Washington, 1976.

9. R. M. Emery and M. C. McShane, Comparative Ecology of Nuclear Waste Ponds and Streams on the Hanford Site, PNL-2499, Pacific Northwest Laboratory, Richland, Washington, 1978.

10. K. D. Carland, "The Standing Crop of Fish in Lakes", Journal of Fishery Research Board of Canada, 12.

11. C. E. Cushing, "Periphyton Productivity and Radionuclide Accumulation in the Columbia River Washington, U.S.A.," Hydrobiologia, 29, 1967.

12. W. C. Hanson and L. E. Eberhardt, "A Columbia River Canadian Goose Study", Wildlife Monographs No. 28, 1971. 
13. R. R. Olendorff, The Large Birds of Prey in the Pawnee National Grassland; Nesting Habits and Productivity, International Biological Program Grass land Biome Technical Report 151, National Academy of Sciences, 1972.

14. J. K. Sheldon and L. E. Rogers, Grasshopper Populations Inhabiting the B-C Cribs and Redox Pond Sites, 200 Area Plateau, U. S. Energy Research and Development Administration Hanford Reservation, BNWL-1943, Battelle, Pacific Northwest Laboratory, Richland, Washington, 1976.

\section{CHAPTER 4.0}

1. U. S. Energy Research and Development Administration, Final Environmental Statement, Waste Management Operations, Hanford Reservation, Richland, Washington, ERDA-1538, 2, Washington, D.C., 1975.

2. W. A. Stone, D. E. Jenne, and M. J. Thorp, Climatology of the Hanford Area, "BNWL-1605, Battelle, Pacific Northwest Laboratory, Richland, Washington, June 1972.

CHAPTER 5.0

1. The National Atlas of the United States, U.S. Geological Survey, U.S. Government Printing Office, 1970.

2. Washington Public Power Supply System Nuclear Project Number $1_{2}$ Preliminary Safety Analys is Report, Amendment 9, Richland, Washington, 1974.

3. R. W. Fairbridge, Editor, The Encyclopedia of World Regional Geology, Part 1, Dowden, Hutchinson and Rose, Inc., Stroudsburg, Pennsylvania, 1975. 
4. V. R: Baker, Paleohydrology and Sedimentology of Lake Missoula Flooding in Eastern Washington, Geological Society of America Special Paper 144, 1973.

5. J. H. Bretz, Washington's Channeled Scabland, Washington Division of Mines and Geology, Bulletin 45, Olympia, Washington, 1959.

\section{CHAPTER 6.0}

1. R. A. Deju and B. H. Richard, A Regional Gravity Investigation of the Hanford Reservation, ARH-C-8, Alantic Richfield Hanford Company, Richland, Washington, April 1975.

2. R. A. Deju, P. A. Eddy, M. W. Grutzeck, and C. W. Myers, Environmental Factors Needed to Establish the Geotechnical

Feasibility of Storing Radioactive Waste in Columbia River Basalt, RH0-ST-8, Rockwell Hanford Operations, Richland, Washington, September 1977.

3. I. C. Russe11, "A Geological Reconnaissance in Central Washington," U.S. Geological Survey Bulletin, 108, 1893.

4. Staff, Research and Engineering Division, Preliminary Feasibility Study on Storage of Radioactive Wastes in Columbia River Basalts, ARH-ST-137, Atlantic Richfield Hanford Company, Richland, Washington, November 1976 .

5. R. D. MacNish, D. A. Myers, and R. A. Berker, "Appraisal of Groundwater Availability and Management Projections, Walla Walla River Basin, Washington and Oregon," Washington State Water Supply Bulletin, $\underline{57}, 1973$.

6. P. A. Eddy, Ground-Water Hydrology of the Umtanum and Moxee Valleys, Washington State Department of Ecology Open File Report, Olympia, Washington, 1975. 
7. H. H. Tanaka, A. J. Hansen, Jr., and J. A. Skrivan, "Digital-Model Study of Ground-Water Hydrology, Columbia Basin Irrigation Project Area, Washington," Washington State Department of Ecology Water-Supply Bulletin, $\underline{40}, 1974$.

8. J. E. Luzier and R. J. Burt, "Hydrology of Basalt Aquifers and Depletion of Ground Water in East-Central Washington," Washington State Department of Ecology Water-Suppiy Bulletin, 33, 1973.

9. U. S. Energy Research and Development Administration, Final Environmental Statement, Waste Management Operations, Hanford Reservation, Richland, Washington, ERDA-1538, 2, Washington, D.C., 1975.

10. W. K. Summers and R. A. Deju, A Preliminary Review of the Regional Hydrology of the Hanford Reservation, ARH-C-5, Alantic Richfield Hanford Company, Richland, Washington, 1974.

11. "Definition of Selected Groundwater Terms," A Report of the Committee on Redefinition of Groundwater Terms, U.S. Geological Survey Open File Report, 1970.

12: J. L. Glenn, Relations Among Radionuclide Content and Physical, Chemical and Mineral Characteristics of Columbia River Sediments, U.S. Geological Survey, Water Resource Division, Portland, Oregon, 1971.

13. J. L. Nelson and W. L. Haushild, Accumulation of Radionuclides in Bed Sediments of McNary Reservoir of the Columbia River, BNWL-SA-1730, Battelle, Pacific Northwest Laboratory, Richland, Washington, 1968.

11. J. T. Whetten, I. R.. Ke.1 ley, and L. G. Hanson, "Characteristics of Columbia River Sediments and Sediment Transport," Journal of Sedimentary Petrology, 39 (3), 1969. 
15. Water Resources Data for Washington, Part 1, Surface Water Records, $\underline{1972}$, U.S. Geological Survey, 1973.

16. J. K. Soldat, "A Compilation of Basic Data Relating to the Columbia River," Section 8, Dispersion of Reactor Effluent in the Columbia River, HW-69369, General Electric Company, Richland, Washington, 1962.

17. P. E. Bramson and J. P. Corley, Environmental Surveillance at Hanford for CY-1972, BNWL-1727, Battelle, Pacific Northwest Laborat.nry, Richland, Washington, April 1973.

18. R. M. Emery and M. C. McShane, Comparative Ecology of Nuclear Waste Ponds and Streams on the Hanford Site, PNL-2499, Pacific Northwest Laboratory, Richland, Washington, 1978.

19. "Probable Maximum Precipitation, Northwest States," U.S. Department of Commerce, Environmental Science Service Administration, Weather Bureau, Hydro-Meterologic Report Number 43, Washington, D.C., November 1966.

20. Evaluation of Impact of Potential Flooding Criteria on the Hanford Project, RL-76-4, U. S. Energy Research and Development Administration, Richland Operations Office, Richland, Washington, 1976.

\section{CHAPTER 7.0}

1. Washingt.nn Public Power Supply System Nuclcar Project Number 1 Preliminary Safety Analys is Report, Amendment 9, Richland, Washington, 1974.

2. The National Atlas of the United States, U.S. Geological Survey, U.S. Government Printing Office, 1970. 
3. R. K. Ledgerwood, C. W. Myers, and R. W. Cross, Pasco Basin Stratigraphic Nomenclature, RHO-BWI-LD-1, Rockwe 11 Hanford Operations, Richland, Washington, 1978.

4. Staff, Basalt Waste Isolation Program, Annual Report - Fiscal Year 1978, RHO-BWI-78-100, Rockwe11 Hanford Operations, Richland, Washington, 1978.

5. R. A. Deju, P. A. Eddy, M. W. Grutzeck, and C. W. Myers, Environmental Factors Needed to Establish the Geotechnical

Feasibility of Storing Radioactive Waste in Columbia River Basalt, RHO-ST-8, Rockwe 11 Hanford Operations, Richland, Washington, 1977.

6. A. C. Waters, "Stratigraphic and Lithologic Variations in the Columbia River Basalt," American Journal of Science, 259, 1961.

7. A. C. Waters, Volcanic Rocks and the Tectonic Cycle, Geological Society of America Special Paper 62, 1955.

8. H. Kuno, "Plateau Basalts," American Geophysical Union, Geophysical Monographs, 13, 495-501, 1969.

9. J. Gray and L. R. Kittleman, "Geochronometry of the Columbia River Basalt and Associated Floras of Eastern Washington and Western Idaho," American Journal of Science, 265 (4), 257-291, 1967.

10. N. D. Watkins, "Paleomagnetism of the Columbia Plateau," Journal of Geophysical Research, 70 (6), 1379-1406, 1965.

11. J. H. Mackin, A Stratigraphic Section in the Yakima Basalt and the Ellensburg Formation in South-Central Washington, Washington Division of Mines and Genlogy. Report of Investigation No. 19, 01ympia, Washington, 1961. 
12. R. E. Brown, "Some Suggested Rates of Deformation of the Basalts in the Pasco Basin and Their Implications, " in Proceedings of the Second Columbia River Basalt Symposium, Cheney, Washington, March 1969, Eastern Washington State College Press, Cheney, Washington, 1970.

13. A. K. Baksi and N. D. Watkins, "Volcanic Production Rates: Comparison of Oceanic Ridges, Islands, and the Columbia Plateau Basalts," Science, .180, 493-496, 1973.

14. C. W. Myers, Yakima Basalt F Flows Near Vantage and from Core Holes in the Pasco Basin, Washington, Ph.D. Dissertation, University of California at Santa Cruz, Santa Cruz, California, 1973.

15. C. W. Myers and D. J. Brown, "Stratigraphy of the Yakima Basalt in the Pasco Basin, Washington, " (abstract) Geological Society of America (Cordilleran Section), $\underline{5}$ (1), 80, 1973.

16. D. J. Brown and R. K. Ledgerwood, "Stratigraphy and Structure of Yakima Basalt in Pasco Basin, Washington," Geologic Field Trips in Northern Oregon and Southern Washington, Oregon Department of Geology and Mineral Industries Bulletin, $\underline{77}, 171-181,1973$

17. J. R. Raymond and D. D. Tillson, Evaluation of a Thick Basalt Sequence in South-Central Washington, BNWL-776, Battelle, Pacific Northwest Laboratory, Richland, Washington, 1968.

18. K. R. Newman, "Palynology of Interflow Sediments, from the Standard Oil Company of Califnrnia Rattlesnake Hills No. 1 Well, Bcritun County, Washington," in Proceedings of the Second Columbia River Basalt Symposium, Cheney, Washington, March 1969, Eastern Washington State College Press, Cheney, Washington, 1970.

19. I. C. Russe11, "A Geological Reconnaissance in Central Washington," U.S. Geological Survey Bulletin, 108, 1893. 
20. I. C. Russe11, "Geology of the Cascade Mountains in Northern Washington, "U.S. Geological Survey 20th Annual Report, Part 2," 1900.

21. I. C. Russe11, Geology and Water Resources of Nez Perce County, Idaho, U.S. Geological Survey Water Supply Papers 53 and 54, 1901.

22. G. 0. Smith, Geology and Water Resources of a Portion of Yakima County, Washington, U.S. Geological Survey Water Supply Paper 55, 1901.

23. G. 0. Smith, Geology and Physiography of Central Washington, U.S. Geological Survey Professional Paper 19, 1903.

24. G. 0. Smith, "Description of the Ellensburg Quadrangle (Washington)," U. S. Geological Survey, Geological Atlas, El lensburg Folio, Number $86,1903$.

25. G. 0. Smith, "Anticlinal Mountain Ridges in Central Washington," Journal of Geology, 11, 1903.

26. G. 0. Smith, "Mount Stuart Fol.io," U.S. Geological Survey, Geological Atlas, Number 106, 1904.

27. F. C. Calkins, Geology and Water Resources of a Portion of East-Central Washington, U. S. Geological Survey Water Supply Paper $118,1905$.

28. G. A. Waring, Geology and Water Resources of a Portion of South-Central Washington, U. S. Geological Survey Water Supply Paper $316,1913$.

29. R. E. Fuller, "The Closing Phase of a Fissure Eruption," American Journal of Science, 14,1927

30. R. E. Fuller, "The Aqueous Chilling of Basaltic Lava on the Columbia River Plateau," American Journal of Science, $\underline{5}$ (21), 1931. 
31. A. A. Hammer, "Rattlesnake Hills Gas Field," Northwest 0il and Gas World, 1934.

32. S. L. Glover, Preliminary Report on Petroleum and Natural Gas in Washington, Washington Division of Geology Report of Investigation No. 4, Olympia, Washington, 1936.

33. S. N. Twiss, Stratigraphy of Saddle Mountains, M. S. Thesis, Washington State College, Pullman, Washington, 19.3.

34. H. E. Culver, "Extensions of the Ringold Formation," Northwest Science, 11 (2), 1936.

35. J. T. Pardee and K. Bryan, Geology of the Latah Formation in Relation to the Lavas of the Columbia Plateau Near Spokane, Washington, U. S. Geological Survey Professional Paper 140, 1926.

36. J. C. Merriam, "A Contribution to the Geology of the John Day Basin," University of California Department of Geology Science Bullet in No. 2., 1901.

31. J., C. Merriam and J. P. Buwalda, "Age of Strata Referred to the Ellensburg Formation in the White Bluffs of the Columbia River," University of California Department of Geology Science Bulletin No. 10 (15), 1917.

38. W. N. Laval, Stratigraphy and Structural Genlngy of Portions of South Central Washington. Ph.D Disscrtation, University of Washington, Seattle, Washington, 1957.

39. J. H. Mackin, "Diatomite Deposits in Eastern Washington," (abstract) Northwest Science, 21, 1947.

40. J. H. Mackin, Geology of the Priest Rapids Development: Priest Rapids Hydroelectric Development, Columbia River, Washington, Grant County Public Utility District, Ephrata, Washington, 1955. 
41. J. H. Mackin, A Stratigraphic Section in the Yakima Basalt and the Ellensburg Formation in South-Central Washington, Washington Division of Mines and Geology, Report of Investigation No. 19, 1961.

42. B. R. Alto, Geology of a Part of the Boylson Quadrangle and Adjacent Areas in Central Washington, $\dot{M}$.S. Thesis, University of Washingtion, Seattle, Washington, 1955.

43. I. B. Gray, Correlation of the Upper Flows of the Columbia River Basalts Between Moses Coulee and Yakima, Washington, M.S. Thes is, University of Washington, Seattle, Washington, 1955.

44. G. W. Mason, Interbasalt Sediment of South-Central Washington, M.S. Thesis, Washington State College, Pullman, Washington, 1953.

45. A. C. Waters, "Geomorphology of South-Central Washington, Illustrated by the Yakima Basalt Quadrangle," Geological Society of America Bulletin, $\underline{66}, 1955$.

46. Staff, Research and Engineering Division, Preliminary Feasibility Study on Storage of Radioactive Wastes in Columbia River Basalts, ARH-ST-137, Atlantic Richfield Hanford Company, Richland, Washington, 1976.

47. J. F. Evernden and G. T. James, "Potassium Argon Dates and the Tertiary Floras of North America," American Journal of Science, 262 (8), 1964.

48. D. A. Holmgren, "K/Ar Dates and Paleomagnetics of the Type Yakima Basalt, Central Washington," in Proceedings of the Second Columbia River Basalt Symposium, Cheney, Washington, March 1969, Eastern Washington State College Press, Cheney, Washington, 1970. 
49. D. H. Lindsley, The Geology of the Spray Quadrangle, Oregon, with Special Emphasis on Petrography and Magnetic Properties of the Picture Gorge Basalt, Ph.D. Dissertation, The Johns Hopkins University, Baltimore, Maryland, 1960.

50. H. U. Schmincke, Petrology and Paleocurrents and Interbedded Yak ima Basalt Flows, South Central Washington, Ph.D. Dissertation, The Johns Hopkins University, Balt imore, Maryland, 1964.

51. D. A. Swanson, "Yakima Basalt of the Tieton River Area, South-Central Washington," Geological Society of America Bulletin, 78, 1967.

52. M. Osawa and G. Goles, "Trace Element Abundances in Columbia River Basalts," in Proceedings of the Second Columbia River Basalt Symposium, Cheney, Washington, March 1969, Eastern Washington State College Press, Cheney, Washington, 1970.

53. J. W. Bingham and M. J. Grolier, "The Yakima Basalt and Ellensburg Formation in South-Central Washington," U. S. Geological Survey Bulletin, 1224-G, 1966.

54. J. W. Bingham and K. L. Walters, Stratigraphy of the Upper Part of the Yakima Basalt in Whitman and Eastern Franklin Counties, Washington, U. S. Geological Survey Professional Paper 525-C, C86-C90, 1965.

55. H. D. Diery, Stratigraphy and Structure of Yakima Canyon Between Roza Gap and Kittitas Valley, Central Washington, Ph.O. Dissertation, University of Washington, Seattle, Washington, 1967.

56. M. J. Grolier and J. W. Bingham, "Geologic Map and Sections of Parts of Grant, Adams, and Franklin Counties, Washington," U. S. Geological Survey Miscell laneous Geological Inventory Map I-589, Scale 1:62,500, 1971. 
57. N. Simon and J. S. Fruchter, "Geochemical and Paleomagnetic Stratigraphy of the Picture Gorge and Yakima Basalts (Columbia River Group) in Central Oregon," Geological Society of America Bulletin, 85, 1974.

58. T. L. Wright, M. J. Grolier, and D. A. Swanson, "Chemical Variation Related to the Stratigraphy of the Columbia River Basalt," Geological Society of America Bulletin, 84, 1973.

59. P. R. Hooper, "Petrology and Chemistry of the Rock Creek Flow, Columbia River Basalt, Idaho," Geological Society of America Bulletin, $\underline{85}, 1974$.

60. I. McDougal1, "Geochemistry and Origin of Basalt of the Columbia River Group, Oregon and Washington," Geological Society of America Bulletin, 87, 1976.

61. J. H. Bush, Jr., J. V. Anderson, J. W. Crosby, III, and B. A. Siems, Test Observation Well Near Mansfield, Washington - Description, Stratigraphic Relationships and Preliminary Results, Washington State University, College of Engineering Research Report 72, Pullman, Washington, 1972.

62. D. A. Swanson, T. L. Wright, and R. T. Helz, "Linear Vent Systems and Estimated Rates of Magma Production and Eruption for the Yakima Basalt on the Columbia Plateau;" American Journal of Science, 275 (8), 1975.

63. D. A. Swanson and T. L. Wright, "Extent, Source, and Structure of the Roza Member of the Yakima Basalt in Southeast Washington," Geological Society of America (Abstract with Programs), 5 (1), 1973.

64. J. D. Rietman, Remanent Magnetization of the Late Yakima Basalt, Washington State, Ph.D. Dissertation, Stanford University, Stanford, California, 1966. 
65. B. A. Siems, J. H. Bush, and J. W. Crosby, III, "TiO 2 and Geophysical Logging Criteria for Yakima Basalt Correlation, Columbia Plateau," Geological Society of America Bulletin, 85, 1974.

66. P. D. Snavely, Jr., N: S. Macleod, and H. C. Wagner, "Miocene Tholeiitic Basalts of Coastal Oregon and Washington and Their Relations to Coeval Basalts of the Columbia Plateau," Geological Society of America Bulletin, 84, 1973.

67. S. M. Price, A Geochemical Classification of Dikes of the Grande Ronde Swarm, Columbia River Basalt, ARH-SA-202, Atlantic Richfield Hanford Company, Richland, Washington, 1974.

68. N. D. Watkins and A. K. Baksi, "Magnetostratigraphy and Oroclinal Folding of the Columbia River, Steens, and Owyhee Basalts in Oregon, Washington, and Idaho," American Journal of Science, 274, 1974.

69. G. S. Holden, Chemical and Petrographic Stratigraphy of the Columbia River Basalt Group in the Imnaha River Valley Region, Eastern Oregon and Western Idaho, M.S. Thesis, Washington State University, Pullman, Washington, 1974 .

70. G. S. Holden and P. R. Hooper, "Petrology and Chemistry of a Columbia River Basalt Section, Rocky Canyon, West-Central Idaho," Geological Society of America Bulletin, 87 (2), 1976.

71. V. E. Camp, Petrochemical Stratigraphy and Structure of the Columbia River Basalt, Lewiston Basin Area, Idaho-Washington, Ph.D. Dissertation, Washington State University, Pullman, Washington, 1976.

72. W. D. Kleck, Chemistry, Petrography and Stratigraphy of the Columbia River Basalt Group in the Imnaha River Valley Region, Eastern Oregon and Western Idaho, Ph.D. Dissertation, Washington State University, Pullman, Washington, 1976. 
73. C. S. Bard, Mineralogy and Chemistry of Pyroxenes from the Imnaha and Lower Yakima Basalts of West Central Idaho, M.S. Thesis, Washington State University, Pullman, Washington, 1977.

74. S. M. Price, An Evaluation of Dike-Flow Correlation Indicated by Geochemistry, Chief Joseph Dike Swarm, Columbia River Basalt, Ph.D. Dissertation, University of Idaho, Moscow, Idaho, 1977.

75. M. G." Jones and R. D. Landon, Geology of the Nine Canyon Map Area, RHO-BWI-LD-6, Rockwe 11 Hanford Operations, Richland, Washington, 1978.

76. S. P. Reidel, Geology of the Saddle Mountains Between Sentinel Gap and $119^{\circ} 30^{\prime}$ Longitude, RHO-BWI-LD-4, Rockweil Hanford Operations, Richland, Washington, 1978.

77. S. P. Reide1, The Stratigraphy and Petrogenes is of the Grande Ronde Basalt in the Lower Salmon and Adjacent Snake River Canyon, Ph.D. Dissertation, Washington State University, Pullman, Washington, 1978.

78. H. U. Schmincke, "Stratigraphy and Petrography of Four Upper Yakima Basalt Flows in South-Central Washington," Geological Society of America Bulletin, 78, 1967.

79. D. A. Swanson and T. L. Wright, "Guide to Field Trip Between Pasco and Pullman, Washington, Emphasizing Stratigraphy, Vent Areas, and Intracanyon Flows of Yakima Basalt," in Geological Society of America Field Guide Number 1, Cordilleran Section, 72nd Annual Meeting, 1976.

80. D. P. Hi11, "Crustal and Upper Mantle Structure of the Columbia River Plateau from Long Range Seismic Refraction Measurements," Geological Society of America Bulletin, 83, 1972.

81. J. H. Skehan, A Continental-Oceanic Crustal Boundary in the Pacific Northwest, AFCRL-65-904, Air Force Cambridge Research Laboratories, Office of Aerospace Research, Bedford, Massachusetts, 1965. 
82. E. Raisz, "The Olympic-Wallowa Lineament," American Journal of Science, 243-A, 1945.

83. T. Cantwe11, P. Nelson, J. Webb, and A. S. Orange, "Deep Resistivity Measurements in the Pacific Northwest," Journal of Geophysical Research, 70 (8), 1965.

84. S. L. Robbins, R. J. Burt, and D. 0. Gregg, Gravity and Aeromagnetic Study of Part of the Yakima River Basin, Washington, U.S Geological Survey Professional Paper 726-E, 1975.

85. D. E. Peterson and R. E. Brown, Gravity Anomalies and Geologic Structures of the Central Part of the Columbia River Basalt Plateau, BNWL-SA-812, Battelle, Pacific Northwest Laboratory, Richland, Washington, 1966.

86. W. H. Taubeneck, "An Evaluation of Tectonic Rotation in the Pacific Northwest," Journal of Geophysical Research, 71 (8), 2113-2120, 1966, and $\underline{72}, 1967$.

87. A. C. Waters, "Basait Magma Types and Their Tectonic Association: Pacific Northwest of the United States," American Geophysical Union Geophysical Monographs, $\underline{6}, 1962$.

88. A. B. Griggs, "The Columbia River Basalt Group in the Spokane Quidráriyle, Washington, Idaho, änd Montana, " U.S. Geological Survey Bulletin, 1413, 1976.

89. J. C. Merriam and J. P. Buwalda, "Age of the Strata Referred to the Eliensburg Formation in the White Bluffs of the Columbia River," University of California Publication of Geological Sciences, 10 (15), 1916.

90. H. E. Culver, "Extensions of the Ringold Formation," Northwest Science, 11 (3), 1937. 
91. R. C. Newcomb, "Ringold Formation of Pleistocene Age in Type Locality, The White Bluffs, Washington, "American Journal of Science, $\underline{256}$ (5), 1958.

92. E. P. Gustafson, The Vertebrate Fauna of the Late Pliocene Ringold Formation, South-Central Washington, M.S. Thesis, University of Washington, Seattle, Washington, 1973.

93. E. P. Gustafson, The Vertebrate Faunas of the Pliocene Ringold Formation, South-Central Washington, Museum of Natural History Bullet in No. 23, University of Oregon, Eugene, Oregon, 1978.

94. D. J. Brown, An Eolian Deposit Beneath 200 West Area, HW-67549, General Electric Company, Richland, Washington, 1970.

95. V. R. Baker, Paleohydrology and Sedimentology of Lake Missoula Flooding in Eastern Washington, Geological Society America Special Paper 144, 1973.

96. J. H. Bretz, Washington's Channeled Scabland, Washington Division of Mines and Geology, Bullet in 45, Olympia, Washington, 1959.

97. R. F. Flint, "Origin of the Cheney-Palouse Scabland Tract," Geological Society of America Bulletin, 49, 1938.

98. D. R. Mullineaux, R. E. Wilcox, W. F. Ebaugh, R. Fryxell, and M. Rubin, "Age of the Last Major Scabland Flood of Eastern Washington, As Inferred from Associated Ash Beds of Mount St. Helens Set S," Geological Society of America, Abstracts with Programs, g, 1977.

99. R. Fryxe11, "Mazama and Glacier Peak Volcanic Ash Layers, Ple istócene Ages," siience, 147, 1965.

100. B. F. Hajek, Soil Survey, Hanford Projert. in Benton County, Washington, BNWL-243, Battelle, Pacific Northwest Laboratory, Richland, Washington, 1966. 
101. R. C. Newcomb, J. R. Strand, and F. J. Frank, Geology and Ground-Water Characteristics of the Hanford Reservation of the U.S. Atomic Energy Commission, Washington, U.S. Geological Survey Professional Paper 717, 1972.

102. J. T. Lillie, A. M. Tallman, and J. A. Caggiano, Preliminary Geologic Map of the Late Cenozoic Sediments of the Western Half of the Pasco Basin, RHO-BWI-LD-8, Rockwe1l Hanford Operations, Richland, Washington, 1978.

103. Washington Public Power Supply System Nuclear Project Number 1, Preliminary Safety Analys is Report, Amendment 9, Richland, Washington, 1974.

104. M. J. Grolier, Geology of Part of Big Bend Area in the Columbia Plateau, Washington, Ph.D. Dissertation, The John Hopkins University, Baltimore, Maryland, 1965.

105. R. E. Brown, Reported Faulting in the Pasco Basin, BNWL-SA-1704, Battelle, Pacific Northwest. I ahoratory, Richland, Washington, 1968.

106. J. W. Bingham, C. J. Londquist, and E. H. Baltz, Geologic Investigations of Faulting in the Hanford Region, Washington. U.S Geological Survey Open File Report, 1970.

107. J. N. Gardner, "Stratigraphy and Faulting of Columbia River Basalts in Wallula Gap," (abstract), E0S, 58, 1977.

108. F. 0. Jones and R. J. Deacon, Geologic and Tectonic History of Hanford Area, DUN-3625, Douglas United Nuclear, Richland, Washington, 1966.

109. F. E. Goff, "Stratigraphy and Tectonics of East Umtanum Ridge, South Central Washington", EOS, 트, 1977. 
110. E. Raisz, "The 0lympic-Wallowa Lineament," American Journal of Science, 253, A Dale Volume, 1945.

111. J. A. Blume and Associates, Supplementary Geologic Investigations for Seismic Evaluation of the FFTF Site, Near Richland, Washington, JABE-WADCO-04, San Francisco, California, 1971.

112. D. A. Swanson, T. L. Wright, V. E. Camp, J. N. Gardner, R. T. Helz, S. M. Price, and M. E. Ross, Reconnaissance Geologic Map of the Columbia River Basalt Group, Pullman and Walla Walla Quadrangles Southeast Washington and Adjacent Idaho, U.S Geological Survey Open File Map 77-100, 1977.

113. V. E. Livingston, $0 i 1$ and Gas Exploration in Washington 1900-1957, Washington Division of Geology and Earth Resources Information Circular No. 29, Olympia, Washington, 1958.

\section{CHAPTER 8.0}

1. S. T. Algermissen and D. M. Perkins, A Probabilistic Estimate of Maximum Acceleration in Rock in the Contiguous United States, U.S Geological Survey Open File Report 76-416, 1976.

2. Washington Public Power Supply System Nuclear Project Number 1, Preliminary Safety Analys is Report, Amendment 9, Richland, Washington, 1974.

3. Shannon and Wilson, Inc., Geologic Studies in the 1872 Earthquake Epicentral Region, report submitted to Washington Public Power Supp.ly System, Inc., Richland, Washington, 1977.

4. C. E. Gịss and ח. B. Slemmons, Imagery and Topographic Interpretation of Geologic Structures in Central Washington, prepared for Washington Public Power Supply System,. Inc., Richland, Washington, 1977. 
5. D. B. Slemmons, G. Carver, and D. T. Trexler, Remote Sensing Analys is of the 1872 Earthquake Epicentral Region, prepared for Washington Public Power Supply System, Inc., Richland, Washington, 1977.

6. H. A. Coombs, W. G. Milne, 0. W. Nuttii, and D. B. Slemmons, Report of the Review Panel on the December 14, 1872 Earthquake, submitted to Washington Public Power Supply System, Inc., Richland, Washington, 1976.

7. Woodward-Clyde Consultants, Review of the North Cascade Earthquake of December 14, 1872, submitted to Washington Public Power Supply System, Inc., Richland, Washington, 1977.

8. Shannon and W11son Consultants, 1872. Earthquake: New. Data from Oregon, submitted to Portland General Electric Company, Portland, Oregon, 1976.

9. Weston Geophysical Research, Geophysical and Seismological Studies in the 1872. Earthquake Epicentral Region, submitted to Washington Public Power Supply System, Inc., Rirhland, Washington, 1977.

10. Weston Geophysical Research, Geophysical Evaluation of Structures in the Columbia Plateau, submitted to Washington Public Power Supply System, Inc., Richland, Washington, 1977.

11. G. A. Davis, Tectonic Evolution of the Pacific Northwest Precambrian to Present, submitted to Washington Public Power Supply System, Inc., Richland, Washington, 1977.

12. Woodward-Clyde Consultants, Microearthquake Survey and Evaluation of Stress Orientation in Central Washington, submitted to Washington Public Power Supply System, Inc., Richland, Washington, 1977.

13. Weston Geophysical Research, Evaluation of Microearthquake Activity in Eastern Washington, submitted to Washington Public Power Supply System, Inc., Richland, Washington 1977. 
14. H. A. Coombs, G. A. Davis, D. Tocher, and D. D. Tillson, New Geological and Geophysical Information about the December 14, 1872 Earthquake Source Area and the Columbia Plateau: Summary Report, submitted to Washington Public Power Supply System, Inc., Richland, Washington, 1977.

15. Shannon and Wilson Consultants, Geologic Evaluation of Structures in the Columbia Plateau, submitted to Washington Public Power Supply System, Inc., Richland, Washington,, 1977.

16. S. R. Brockman, R. H. Morris, and W. H. Hays, Supplement to Final Review, Washington Public Power Supply System, Washington Nuclear Projects Nos. 1 and 4, Hanford Reservation, Washington, Docket Nos. 50-460/513, U.S. Nuclear Regulatory Commission, Washington, D.C. December 1977.

17. NRC Staff, Supplemental Test1mony, R. MeMullen and J. Kelleher on Geology and Seismology Before the Atomic Safety and Licensing Board, Washington, D.C., January 12, 1978.

18. Safety Evaluation of the Washington Nuclear Project 1, 4 Nuclear Power Stations, Docket Nos. 50-460/513, NUREG-75/036, U.S. Nuclear Regulatory Commission, Office of Reactor Regulations, Washington, D.C., May 1975.

19. F. Neumann, United States Earthquakes, 1936, Washington, U.S. Department of Commerce, Washington, D. C,. Ser. \#610, 1938.

20. F. 0. Jones and R. J. Deacon, Geology and Tectonic History of the Hanford Area and its Relation to the Geology and Tectonic History of the State of Washington and the Active Seismic Zones of Western Washington and Western Murlaria, DUN-1410, Douglas Uniterd Nuclear, Richland, Washington, 1966. 
21. R. H. Jahns, Geologic Factors Relating to Engineering Seismology in the Hanford Area, DUN-3100, Douglas United Nuclear, Richland, Washington, 1967.

22. J. W. Bingham, C. J. Londquist, and E. H. Baltz, Geologic Investigations of Faulting in the Hanford Region, Washington, U.S. Geological Survey Open File Report, 1970.

23. F. A. Düralh and R. B. Parker, "Folds and Folding," Geological Society of Amerira Bulletin, 75, 1964.

24. F. E. Goff, "Stratigraphy and Tectonics of East Umtanum Ridge, South-Central Washington," (abstract), EOS, 트, 1977.

25. N. F. Fifer, Earthquake Studies of the Hanford Area, DUN 3625, Douglas United Nuclear, Richland, Washington, 1968.

26. M. G. Jones and K. R. Fecht, "Exploratory Trenching Across the Wallula Gap Fault, South Central Washington", (abstract), EOS, $\underline{58}$, 1977.

27. F. Neumann, Earthquake Intensity and Related Ground Motion, University of Washington Press, Seattle, Washington, 1954.

28. M. D. Trifunac and A. C. Brady, "On the Correlation of Seismic Intensity Scales with Peaks of Recorded Strong Ground Motion," Seismological Society of America Bulletin, 65, 1975.

29. J. K. Murphy and J. O'Brien, "The Correlation of Peak Ground Acceleration Amplitude with Seismic Intensity and Other Physical Parameters," Seismological Society of America Bulletin, 67.

30. J. W. Skehan, A Continental-0ceanic Crustal Boundary of the Pacific Northwest, AFCRL-65-904, Scientific Report 3, Air Force Cambridge Research Laboratory, Bedford, Massachusetts, 1965. 
$10-24$

RHO-BWI-CD-31

CHAPTER 9.0

1. National Register of Historic Places, U.S. Department of the Interior, National Park Service, February 1973, and monthly supplements through November 1973.

2. National Registry of Natural Landmarks, U.S. Department of the Interior, National Park Service, September 1973.

3. D. G. Rice, Archeological Reconnaissance - Ben Frank lin Reservoir, 1968, Laboratory of Anthropology, Washington State University, Pullman, Washington, 1968.

4. D. G. Rice, Archeological Reconnaissance - Hanford Atomic Works, Washington State University, Pullman, Washington, 1968. 
APPENDIX

\section{DESCRIPTION AND PROPERTIES OF COLUMBIA RIVER BASALT}

\section{A.1 PETROGRAPHIC CHARACTERISTICS}

The Columbia River Basalt is classed as tholeitic basalt on the basis of its chemistry and mineralogy. Not all flows within the Pasco Basin fit this classification because of their higher alkali content. The common minerals present in the basalt are plagioclase, clinopyroxene, olivine, opaque minerals (such as magnetite and ilmenite), apatite, and mineraloids (chlorophaeite). Tachylyte, a basalt glass crowded with crystallites, is abundant in most flows. The plagioclase is usually labradorite where it occurs as large phenocrysts, but may range from labradorite to andesine in the groundmass. 0livine is usually altered to clay minerals or Mg-chlorite. The pyroxene present is augite and/or pigeonite. The texture is aphanitic with rare large phenocrysts present in some flows. Although some flows in the Pasco Basin are quite glassy, most exhibit intersertal to intergranular textures. Some show a patchy diktytaxitic ophimottling. The color of the rock is generally gray to black on a fresh surface. Some flows have reddish-orange to reddish-brown weathered surfaces that result from the oxidation of iron in iron-rich clay and mineraloid present in the flow.

\section{A.2 INTRAFLOW STRUCTURES ${ }^{(1)}$}

Columnar joints are the most common internal structures within individual flows of the Columbia River Basalt (Figure A.1). Although the pattern of columnar jointing exhibits variability, both within and between flows, a typical flow usually consists of: (a) a lower zone (the colonnade) generally one-third to one-half the thickness of the entire flow, consisting of nearly symmetrical columnar joints defining prismatic columns oriented approximately perpendicular to the flow top; and (b) an upper zone (the entablature) generally one-half to two-thirds the thickness of the entire flow, consisting of a much more irregular jointing pattern where columnar joints, if present, are less distinct than in the colonnade. Jointing pattern variations include fan-like columnar joints, platy joints, swirling joints, brick-bat joints, 


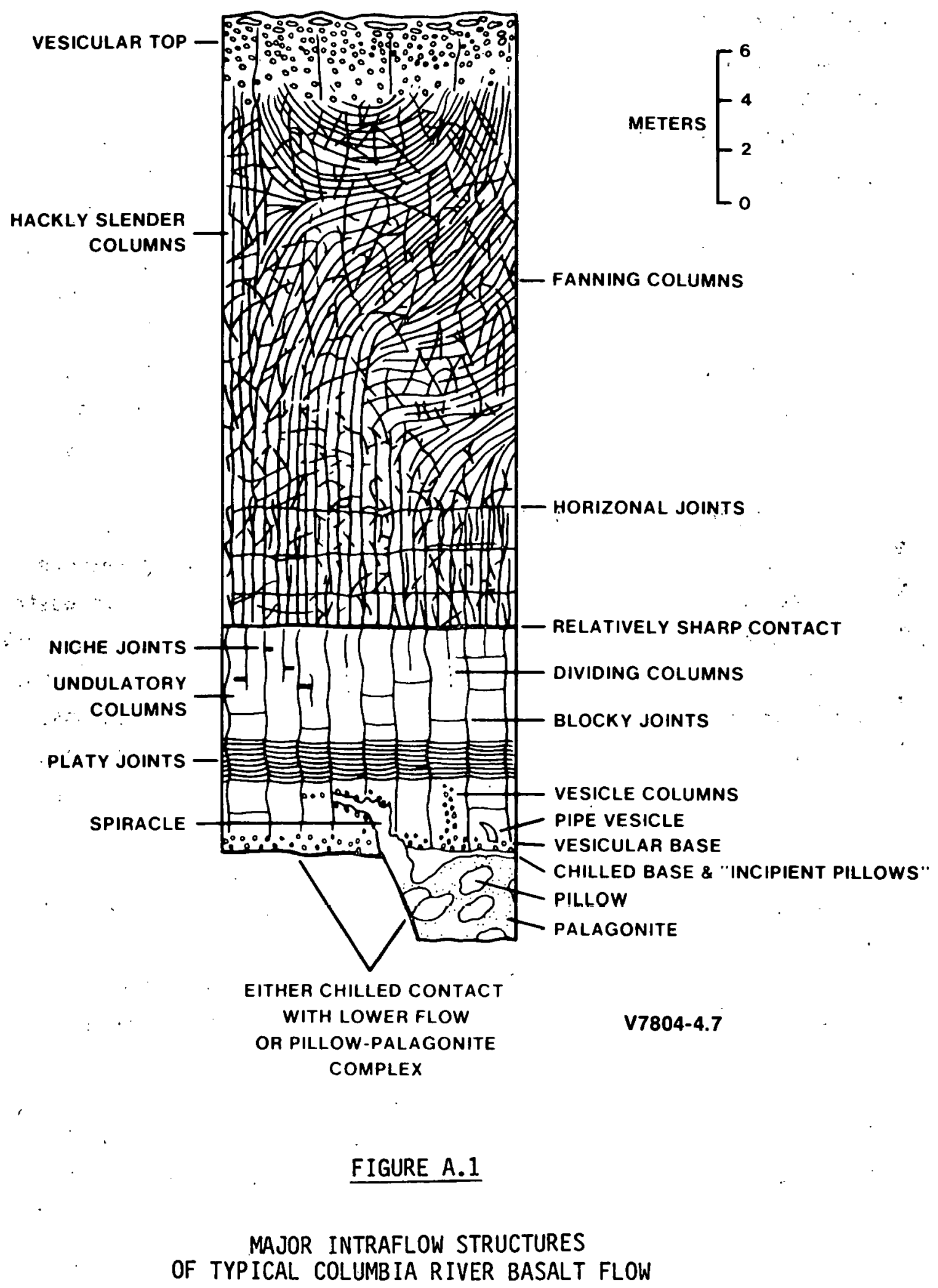


cross joints, niche joints, blocky joints, hackly joints, and discontinuous joints. ${ }^{(2-16)}$ Vesicular flow tops, often scoriaceous, are ubiquitous and most flows have a thin vesicular zone at the base. In addition, laterally extensive vesicular zones are internal to some flows, as are pipe vesicles and vesicle cylinders. $(17,18)$ Basal parts of many flows contain spiracles and brecciated pillow complexes. $(17,19)$ flow tops may be weathered to various degrees, and some are capped by a sedimentary unit. Abrupt lateral changes in joint patterns can occur. Examples include the sudden appearance or disappearance of pillnw complexes, or an abrupt change in the pattern of cooling joints. At depth, most joints and fractures are filled with secondary minerals such as zeolites, amorphous iron-rich silicates, and ferro-magnesian clays.

\section{A.3 PHYSICAL PROPERTIES OF COLUMBIA RIVER BASALT ${ }^{(20)}$}

The physical properties of Columbia River Basalt are being measured for use in conceptual engineering design studies for a radioactive waste repository. For a repository at 1,000 meters below the surface, the rock stresses around the excavations, except for local stress concentrations, will be of the order of 30 to 40 megapascals. Around the excavations, the minor principal stress, or the confining stress, will be much. lower. than this figure. The rock temperatures, although dependent upon the thermal loading density, are unlikely to rise by more than 150 to $250^{\circ} \mathrm{C}$, except for very locally near the canisters. Around the repository, the rock mass should behave in an elastic manner with brittle mode of failure. (21)

Since basalt is a highly jointed rock, the properties of the mass will be controlled by the jointing. The laboratory testing program for Columbia River Basalt cores is designed, therefore, to test both intact and jointed cores. A broad group of basic engineering tests was conducted on core samples ranging in depth from 30 to greater than 1,200 meters in widely separated holes in and around the Hanford Site. The testing program is designed to gain basic input data for numerical models 
as well as to determine the lateral and vertical variations of properties between and within flows. The basic conclusions from the data are:

1. The properties of the Columbia River basalts are well within the expected range for average basalt (Table A.1);

2. Within the central portion of dense basalt flows, the horizontal or vertical variations in properties are insignificant;

3. The thermal conductivity and thermal expansion coefficient vary little with temperature over the range of 0 to $300^{\circ} \mathrm{C}$ (the specific heat varies significantly over the temperature range of 0 to $300^{\circ} \mathrm{C}$ );

4.: The intact core specimens behave elastically with brittle failure mode;

5. Properties vary significantly with porosity and jointing.

The results of testing show that Columbia River Basalt has an average uniaxial compressive strength of approximately 300 megapascals with a Young's Modulus and Poisson's Ratio of 77 gigapascals and .25, respectively. Triaxial compression tests were performed with confining pressures of up to 70 megapascals at constant strain rate. At low confining pressures (less than 15 megapascals), the effects of confinement are small arid are difficult to distinguish. At higher confining pressure (greater than 20 megapascals), the increase in strength is significant. Cohesions of the intact material average 40 megapascals, with friction angles around 50 to 60 degrees. Joint friction angles average in the range of 30 to 45 degrees. These joints were dry with little or no infillings. Seismic velocity measurements indicate an average compressional wave velocity of 5,600 meters per second and a shear wave velocity of 3,500 meters per second. Comparison of axial to diametral velocities indicates a randunii anisotropy. This anisotropy is most likely caused by random, localized jointing. Bulk and grain densities average 2.82 and 2.87 grams per cubic centimeter, respectively, with an average of 1 percent intact porosity. $(22)$ 


\section{TABLE A.1}

PROPERTIES OF THE COLUMBIA PLATEAU BASALTS WITHIN EXPECTED RANGE FOR AVERAGE BASALT

\begin{tabular}{|c|c|c|c|c|}
\hline PROPERTY & UNITS & $\begin{array}{l}\text { VALUE FOR } \\
\text { COLUMBIA } \\
\text { PLATEAU } \\
\end{array}$ & RANGE & $\begin{array}{l}\text { FOR AVERAGE } \\
\text { BASALT }\end{array}$ \\
\hline Grain Density & $\mathrm{glil} / \mathrm{cm}^{3}$ & 2.87 & 2.4 & -3.1 \\
\hline Thermal Conductivity & $\mathrm{cal} / \mathrm{cm}-\sec ^{\circ} \mathrm{C}$ & $3.6 \times 10-3$ & 3.35 & $-10 \times 10-3$ \\
\hline Specific Heat & $\frac{\mathrm{cal}}{\mathrm{gm}-{ }^{\circ} \mathrm{C}}$ & .35 & .23 & -.25 \\
\hline Thermal Expansion & $1{ }^{\circ} \mathrm{C}$ & $6.6 \times 10-6$ & 2.9 & $-11.6 \times 10-6$ \\
\hline Young's Modulus & $\mathrm{GPa}$ & 77 & 61 & -112 \\
\hline Poisson's Ratio & - & .25 & .22 & .28 \\
\hline $\begin{array}{l}\text { Uniaxial Compressive } \\
\text { Strength }\end{array}$ & $\mathrm{MPa}$ & 284 & 0 & -400 \\
\hline Angle of Internal & $x^{0}$ & 55 & 45 & -60 \\
\hline Tensile Strength & Mpa & 21 & 0 & -23 \\
\hline
\end{tabular}


The thermal expansion coefficient averages $6.6 \times 10^{-6}$ per degree Centigrade and varies insignificantly with temperature over the range of 0 to 300 degree Centigrade. The thermal conductivity averages $3.6 \times 10^{-3}$ calories per centimeter-second-degrees centigrade, and its variation is flat over the temperature range of 0 to $300^{\circ} \mathrm{C}$. The conductivity shows a definite increase with density, as is expected (Figure A.2). The specific heat varies by over 50 percent over the temperature range of 0 to $300^{\circ} \mathrm{C}$, with an average value of .5 calories per gram degrees centigrade. There appears to be a random variation with density. 


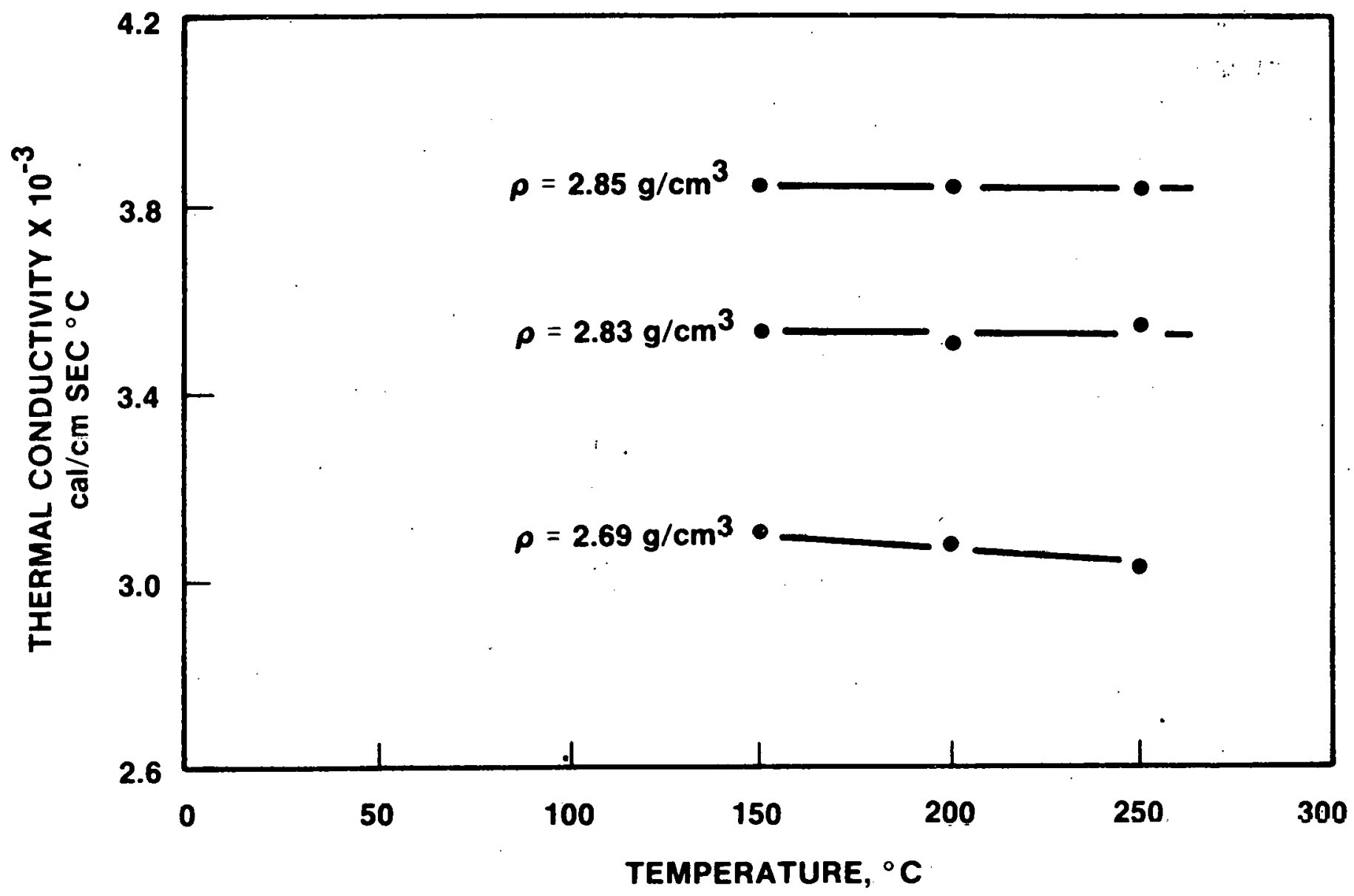

FIGURE A.2

EFFECT OF TEMPERATURE ON THERMAL CONDUCTIVITY

DRILL HOLE DC-10 


\section{A.4 REFERENCES}

1. R. A. Deju, P. A. Eddy, M. W. Grutzeck, and C. W. Myers, Environmental Factors Needed to Establish the Geotechnical

Feasibility of Storing Radioactive Waste in Columbia River Basalt, RHO-ST-8, Rockwell Hanford Operations, Richland, Washington, 1977.

2. S. I: Tomkeiff, "The Basalt Lavas of the Giant's Causeway District of Northern Ireland," Bulletin of Volcanism, $6,1940$.

3. J. H. Mackin, A Stratigraphic Section in the Yakima Basalt and the Ellensburg Formation in South-Central Washington, Washington Division of Mines and Geology, Report of Investigation No. 19, 01ympia, Washington, 1961.

4. C. W. Myers, Yakima Basalt Flows Near Vantage and from Core Holes in the Pasco Basin, Washington, Ph.D. Disssertation, University of California at Santa Cruz, Santa Cruz, California, 1973.

5. W. N. Laval, Stratigraphy and Structural Geology of Portions of South Central Washington, Ph.D. Dissertation, University of Washington, Seattle, Washington, 1957.

6. J. H. Mackin, "Diatomite Deposits in Eastern Washington,". (abstract) Northwest Science, 21 (33), 1947.

7. J. H. Mackin, Geology of the Priest Rapids Development: Priest Rapids Hydroelectric Development, Columbia River, Washington, Grant County Public Utility District, Ephrata, Washington, 1955.

8. B. R. Alto, Geology of a Part of the Boylson Quadrangle and Adjacent Areas in Cenliral Washington, M.S. Thesis, llniversity of Washington, Seattle, Washington, 1955. 
9. I. B. Gray, Correlation of the Upper Flows of the Columbia River Basalts Between Moses Coulee and Yakima, Washington, M.S. Thesis, University of Washington, Seattle, Washington, 1955.

10. G. W. Mason, Interbasalt Sediment of South-Central Washington, M.S. Thesis, Washington State College, Pullman, Washington, 1953.

11. A. C. Waters, "Geomorphology of South-Central Washington, Illustrated by the Yakima Basalt Quadrangle," Geological Society of America. . . Bulletin, 66, 1955.

12. H. U. Schmincke, Petrology and Paleocurrents and Interbedded Yakima Basalt Flows, South Central Washington, Ph.D. Dissertation, The Johns . Hopkins University, Baltimore, Maryland, 1964.

13. D. A. Swanson, "Yakima Basalt of the Tieton River Area, South-Central Washington," Geological Society of America Bulletin, 78, 1967.

14. J. W. Bingham, C. J. Londquist, and E. H. Baltz, Geologic Investigation of Faulting in the Hanford Region, Washington, U. S. Geological Survey Open File Report, 1970.

15. A. Spry, "The Origin of Columnar Jointing Particularly in Basalt Flows," Geological Society of Australia, $8,1962$.

16. R. H. Lefebure, "Colımhia River Basalts of the Grand Cuulee Area," In Proceedings of the Second Columbia River Basalt Symposium, Cheney, Washington, March 1969, Eastern Washingt.nn State College Press, Cheney, Washington, 1970.

17. A. C. Waters, "Determining Flow Direction in Basalts, "American Journal of Science, Bradley Volume C-258-A, 1960.

18. G. A. MacDonald, "Forms and Structures of Extrustive Basaltic Rocks," Basalts: The Poldervaart Treatise on Rocks of Basaltic Composition, Interscience Publishers, $1,1967$. 
19. R. E. Fuller, "The Aqueous Chilling of Basaltic Lava on the Columbia River Plateau," American Journal of Science, $\underline{5}$ (21), 1931.

20. M. P. Board, "The Thermal and Mechanical Properties of Columbia Plateau Basalt," in Basalt Waste Isolation Program Annual Report Fiscal Year 1978, RH0-BWI-78-100, Rockwell Hanford Operations, Richland, Washington, October, 1978.

21. J. F. T. Agapito, M. P. Hardy, and D. R. St. Laurent, Geo-Engineering Review and Proposed Program Outline for the Structural Design of a Radioactive Waste Repository in Columbia Plateau Basalts, RH0-ST-6, Rockwell Hanford Operations, Richland, Washington, September 1977.

22. W. I. Duvall, R. J. Miller, and F. D. Wang, Prel iminary Report on Physical and Thermal Properties of Basalt; Drill Hole DC-10; Pomona Flow-Gable Mountain, RHO-BWI-C-11, Rockwell Hanford Operations, Richland, Washington, May 1978. 
Number of
Copies

1

1

6

1

1

3

18
AMOCO

G. Servos

ATOMICS INTERNATIONAL

H. C. Wieseneck

BATTELLE-OFFICE OF NUCLEAR WASTE ISOLATION

N. E. Carter

Library (5)

BECHTEL INCORPORATED

R. A. Langley, Jr.

CALIFORNIA ENERGY RESOURCES CONSERVATION

AND DEVELOPMENT COMMISSION

E. Varanini

LAWRENCE LIVERMORE LABORATORY

L. D. Ramspott

LOS NLAMOS SCIENTIFIC LABORATORY

K. Wolfsberg

NATIONAL ACADEMY OF SCIENCES
W. E. Berg
U.. Valey
S. Stuen

NATIONAL ACADEMY OF SCIENCES - COMMITTEE ON RADIOACTIVE WASTE MANAGEMENT
M. Baram
S. N. Davis
E. L. Draper
P. W. Durbin
J. T. Edsall
M. Eisenbud
J. A. Fay
J. C. Frye
E. F. Gloyna
H. L. James
R. E. Kasperson 


\section{Number of \\ Copies}

3

5

I. Remson

1

1

1

1

1

?

1

J. P. Corley

L. D. Tyler

W. D. Weart

C. Jones

K. Woods
PACIFIC NORTHWEST LABORATORY

SANDIA LABORATORIES

E. H. Beckner

R. C. Lincoln

A. E. Stephenson

STANFORD UNIVERSITY

STATE OF IDAHO GOVERNOR'S OFFICE

STATE OF OREGON GOVERNOR'S OFFICE

STATE OF WASHINGTON GOVERNOR'S OFFICE

D. Jankins

SWEDISH NUCLEAR FUEL SUPPLY COMPANY (KBS)

L. B. Nillson

U. S. BUREAU OF MINES

J. W. Corwine

U. S. DEPARTMENT OF ENERGY-ALBUQUERQUE OPERATIONS OFFICE

D. T. Schueler

U. S. DEPARTMENT OF ENERGY - COLUMBUS PROGRAM OFFICF

J. 0. Neff 
Number of Copies

5

U. S. DEPARTMENT OF ENERGY-HEADQUARTERS
C. R. Cooley
M. W. Frej
C. H. George
C. A. Heath
D. L. Vieth

1 U. S. DEPARTMENT OF ENERGY-NEVADA OPERATIONS OFFICE

R. M. Nelson, Jr.

U. S. DEPARTMENT OF ENERGY-PUBLIC READING ROOMS

Richland, Washington

Seattle, Washington

6

U. S. DEPARTMENT OF ENERGY-RICHLAND OPERATIONS OFFICE

T. A. Bauman

R. B. Goranson

A. G. Lassila

B. L. Nicoll

D. J. Squires

F. R. Standerfer

U. S. GEOLOGICAL SURVEY
C. Collier
G. D. DeBuchananne
R. Schneider
P. R. Steven
D. A. Swanson
W. S. Twenhofe?

U. S. NUCLEAR REGIII ATORY COMMISSION
R. Boyle
J. 0. Bunting, Jr.
J. C. Malaro
J. B. Martin
E. P. Regnier

WASHINGTON PUBLIC POWER SUPPLY SYSTEM, INC.

D. D. Tillson

P. M. Grimstad 
Number of

Copies
WASHINGTON STATE DEPARTMENT OF NATURAL RESOURCES

V. K. Livingston

A. C. WATERS

WESTINGHOUSE WIPP PROJECT

R. C. Mairson

ROCKWELL HANFORD OPERATIONS

H. Babad

D. J. Brown

D. J. Cockeram

T. A. Curran

R. A. Deju

R. R. Eggleston

K. R. Fecht (20)

R. D. Fox

R. J. Gimera

W. F. Heine

G. S. Hunt

R. E. Isaacson

G. V. Last

A. G. Law

J. T. Lillie

M. C. Marratt

C. W. Myers

S. M. Price

W. H. Price

R. C. Routson

A. M. Tallman

E. White

D. D. Wodrich

Basalt Waste Isolation Program Library (25)

Document Control (4)

Earth Science Library (5)

Records Retention Centers (2) 